\author{
UNIVERSIDADE DE SÃO PAULO \\ ESCOLA DE COMUNICAÇÕES E ARTES \\ PROGRAMA DE PÓS-GRADUAÇÃO EM CIÊNCIA DA INFORMAÇÃO
}

\title{
REBECA LILIAN RODRIGUES
}

Análise da política de formação de acervo e serviços relacionados: estudo de caso da Biblioteca Francisco Montojos do Instituto Federal de Educação, Ciência e Tecnologia de São Paulo (IFSP) - Campus São Paulo 
REBECA LILIAN RODRIGUES

Análise da política de formação de acervo e serviços relacionados: estudo de caso da Biblioteca Francisco Montojos do Instituto Federal de Educação, Ciência e Tecnologia de São Paulo (IFSP) - Campus São Paulo

Dissertação apresentada ao Programa de PósGraduação em Ciência da Informação da Escola de Comunicações e Artes da Universidade de São Paulo para obtenção do título de Mestre em Ciências

Curso: Mestrado Profissional em Gestão da Informação

Área de Concentração: Organização, Mediação e Circulação da Informação

Orientação: Prof. Dr. Lourival Pereira Pinto 
Autorizo a reprodução e divulgação total ou parcial deste trabalho, por qualquer meio convencional ou eletrônico, para fins de estudo e pesquisa, desde que citada a fonte.

Catalogaçäo na Publicação

Serviço de Biblioteca e Documentação

Escola de Comunicaçöes e Artes da Universidade de Säo Paulo

Dados inseridos pelo(a) autor(a)

Rodriguea, Rebeca Lilian

Ansiliee da politica de formuçäo de acervo e merviçou

relacionadon : eatudo de cano da Biblioteca Francisco

Montojos do Inatituto Federal de Rducação, Ciencia e

Tecnologia de ș̄o Paulo (IPSP) - Campua säo Paulo/ Rebeca

Tecnologia de São Paulo (IFSP) - Campua Säo Paulo / Rebeca

Säo Paulo, 2018.

177 p.: il.

Dimeertaçåo (Mentrado Profimaional) - Bmcola de

Coenuicaçōea e Artea / Univeraidade de São Paulo.

Bibliografia

Versäo corrigida

1. Desenvolvimento de coleçōen 2. Bibliotecan dos Inatitutoa Federaia 3 . Serviço de referencia I. Pinto, Lourival Pereira II. Título.

CDD 21. ed. -020

Blaborado por Sarah Lorenzon Perreira - CRB-8/68B8 
Folha de aprovação

Rebeca Lilian Rodrigues

Análise da política de formação de acervo e serviços relacionados: estudo de caso da Biblioteca Francisco Montojos do Instituto Federal de Educação, Ciência e Tecnologia de São Paulo (IFSP) - Campus São Paulo

\section{BANCA EXAMINADORA}

Prof $^{a}$ Dr $^{\mathrm{a}}$. Asa Fujino

Escola de Comunicações e Artes
Prof $^{a}$ Dra $^{\mathrm{a}}$. Valéria Martin Valls

Fundação Escola de Sociologia e Política de São Paulo
Dra $^{\mathrm{a}}$. Andréia Gonçalves Silva

Força Aérea Brasileira
Dr. Lourival Pereira Pinto

Orientador

Universidade Federal de Pernambuco (UFPE) 
"Por que as pessoas perguntam sobre o que se trata o livro? Como se um livro tivesse que ser sobre uma coisa só". Chimamanda Ngozi Adichie 


\section{Eduardo e Mônica}

\section{Legião Urbana}

Compositor: Renato Russo

Quem um dia irá dizer que existe razão

Nas coisas feitas pelo coração? E quem irá dizer

Que não existe razão?

Eduardo abriu os olhos mas não quis se levantar

Ficou deitado e viu que horas eramp

Enquanto Mônica tomava um conhaque

No outro canto da cidade

Como eles disseram

Eduardo e Mônica um dia se encontraram sem querer

E conversaram muito mesmo pra tentar se conhecer

Foi um carinha do cursinho do Eduardo que disse

- Tem uma festa legal e a gente quer se divertir

Festa estranha, com gente esquisita

- Eu não estou legal, não aguento mais birita

E a Mônica riu e quis saber um pouco mais

Sobre o boyzinho que tentava impressionar

E o Eduardo, meio tonto, só pensava em ir pra casa

- É quase duas, eu vou me ferrar

Eduardo e Mônica trocaram telefone

Depois telefonaram e decidiram se encontrar

O Eduardo sugeriu uma lanchonete

Mas a Mônica queria ver o filme do Godard

Se encontraram então no parque da cidade

A Mônica de moto e o Eduardo de camelo

O Eduardo achou estranho e melhor não comentar

Mas a menina tinha tinta no cabelo

Eduardo e Mônica eram nada parecidos

Ela era de Leão e ele tinha dezesseis

Ela fazia Medicina e falava alemão

E ele ainda nas aulinhas de inglês

Ela gostava do Bandeira e do Bauhaus

De Van Gogh e dos Mutantes

Do Caetano e de Rimbaud

E o Eduardo gostava de novela

E jogava futebol-de-botão com seu avô

Ela falava coisas sobre o Planalto Central

Também magia e meditação

E o Eduardo ainda estava 
No esquema "escola, cinema, clube, televisão"

E, mesmo com tudo diferente

Veio mesmo, de repente

Uma vontade de se ver

E os dois se encontravam todo dia

E a vontade crescia

Como tinha de ser

Eduardo e Mônica fizeram natação, fotografia

Teatro e artesanato e foram viajar

A Mônica explicava pro Eduardo

Coisas sobre o céu, a terra, a água e o ar

Ele aprendeu a beber, deixou o cabelo crescer

E decidiu trabalhar

E ela se formou no mesmo mês

Em que ele passou no vestibular

E os dois comemoraram juntos

E também brigaram juntos, muitas vezes depois

E todo mundo diz que ele completa ela e vice-versa

Que nem feijão com arroz

Construíram uma casa uns dois anos atrás

Mais ou menos quando os gêmeos vieram

Batalharam grana e seguraram legal

A barra mais pesada que tiveram

Eduardo e Mônica voltaram pra Brasília

E a nossa amizade dá saudade no verão

Só que nessas férias não vão viajar

Porque o filhinho do Eduardo

Tá de recuperação

E quem um dia irá dizer que existe razão

Nas coisas feitas pelo coração? E quem irá dizer

Que não existe razão? 


\section{Agradecimentos}

Aos meus pais (In Memorian) pelo apoio incondicional e por acreditarem que a educação pode mudar destinos.

Á minha irmã Hadassa e cunhado Fagner pela dedicação e suporte.

Á minha amiga Charlene por todos os conselhos e conhecimento acadêmico dividido.

Á minha amiga Waldirene que não me deixou ser vencida pelo cansaço.

Aos colegas de trabalho Natanael, Alex, Karin, Sérgio, Paula, Ricardo e Luciana pelo profissionalismo e companheirismo.

Ao orientador Lourival que na distância se fez presente o melhor que pode.

Á professora Asa pelos diversos auxílios após a qualificação.

Ao professor Marcelo pelas ótimas contribuições.

À família e amigos que compreenderam minhas ausências, agradeço pela paciência e estímulo. Á todos que contribuíram de alguma forma para a concretização deste trabalho. 


\section{RESUMO}

A partir da análise da formação e desenvolvimento de coleções e do serviço de referência e informação realizado na Biblioteca Francisco Montojos do Instituto de Educação, Ciência e Tecnologia de São Paulo - IFSP, este trabalho busca verificar a relação da Política de Desenvolvimento de Coleções existente, com a missão do IFSP além de identificar a percepção dos usuários sobre os serviços oferecidos pela Biblioteca. Para isso, utiliza os métodos descritivo e exploratório, com a aplicação dos instrumentos de coleta de dados e análise documental e questionário. Realiza a análise documental do Plano de Desenvolvimento Institucional (PDI) e da Política de Desenvolvimento de Coleções do IFSP, e aplica questionários à comunidade acadêmica do IFSP campus São Paulo. Os resultados revelam que o Plano de Desenvolvimento Institucional (PDI) reconhece a biblioteca como espaço de apoio ao desenvolvimento do ensino, pesquisa e extensão, e necessidade de alinhamento das ações da biblioteca com as propostas pedagógicas dos cursos oferecidos pela instituição. Da mesma forma a Política de Desenvolvimento de Coleções do IFSP apresenta os objetivos gerais alinhados com o Plano de Desenvolvimento (PDI). Os questionários identificam a percepção da comunidade acadêmica quanto aos pontos fracos do serviço de referência que precisam ser revistos.

PALAVRAS-CHAVE: Desenvolvimento de coleções. Serviço de referência. Serviço de referência e informação. Bibliotecas dos Institutos Federais. Bibliotecas dos Institutos Federais de São Paulo. Biblioteca dos Institutos Federais de Educação, Ciência e Tecnologia de São Paulo 


\begin{abstract}
Based on the analysis of the formation and development of collections and the service of reference and information realized in the Francisco Montojos Library of the Institute of Education, Science and Technology of São Paulo - IFSP, this work seeks to verify the relation of the existing Policy of Development of Collections, with the mission of the IFSP as well as identifying users' perceptions about the services offered by the Library. For this, it uses the descriptive and exploratory methods, with the application of the instruments of data collection and documentary analysis and questionnaire. It performs the documentary analysis of the Institutional Development Plan (IDP) and the Collection Development Policy of the IFSP, and applies questionnaires to the academic community of the IFSP campus São Paulo. The results show that the Institutional Development Plan (IDP) recognizes the library as a space to support the development of teaching, research and extension, and the need to align the library's actions with the pedagogical proposals of the courses offered by the institution. Likewise, the IFSP Collection Development Policy outlines the general objectives aligned with the Development Plan (IDP). The questionnaires identify the perception of the academic community as to the weaknesses of the referral service that need to be reviewed.
\end{abstract}

KEYWORDS: Development of Collections. User study. Reference service. Reference and information service. Libraries in the Federal Institutes. Libraries in the Federal Institutes of Sao Paulo. Libraries in the Institutos Federais de Educação, Ciência e Tecnologia de São Paulo 


\section{LISTA DE ILUSTRAÇÕES}

Figura 1 - Linha do tempo do ensino profissional federal

Figura 2 - Apontamento de unidades dos Institutos Federais. 34

Figura 3 - Mapa dos campi (2016) 38

Figura 4 - Estrutura Organizacional do Instituto Federal de Educação, Ciência e Tecnologia de São Paulo-IFSP. 39

Figura 5 - Tipologia de Bibliotecas 44

Figura 6 - Desenvolvimento de coleções. Abordagem estruturalista. 55

Figura 7 - Processo de desenvolvimento de coleções 56

Figura 8 - Fluxograma da aquisição por compra das indicações das coordenações de curso 


\section{LISTA DE QUADROS}

Quadro 1 - Expansão dos Institutos Federais em 3 fases

Quadro 2 - Unidades implantadas até agosto de 2008...................................................... 36

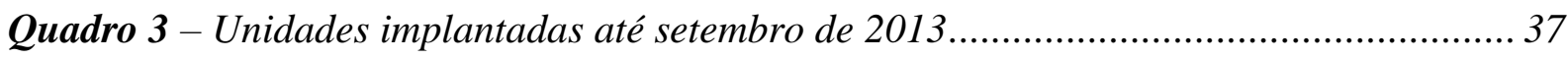

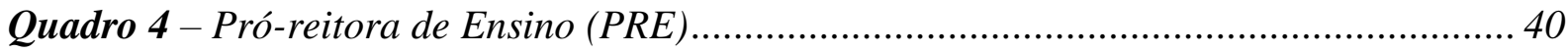

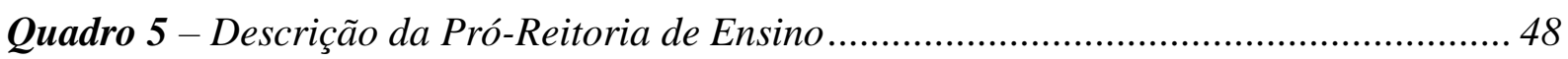

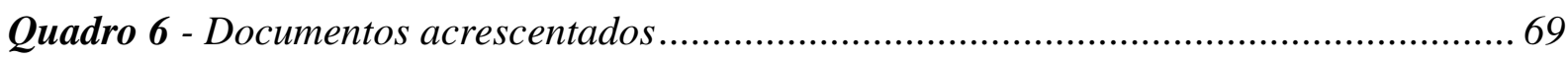

Quadro 7 - Cursos entre as unidades mais antigas do IFSP ........................................... 73

Quadro 8 - Programação de abertura de cursos técnicos (integrado, concomitante e EJA). 78

Quadro 9 - Programação de abertura de cursos de graduação (bacharelados, licenciaturas e

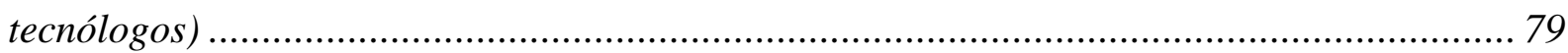

Quadro 10 - Programação de abertura de cursos de EJA - FIC......................................... 79

Quadro 11 - Programação de abertura de cursos de pós-graduação ................................... 80

Quadro 12 - Programação de abertura de cursos a distância ............................................ 80

Quadro 13 - Objetivos e Metas do IFSP para acervos de 2014-2018 ................................. 90

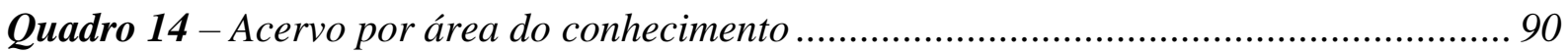

Quadro 15 - Objetivos e Metas do IFSP para bibliotecas de 2014-2018 ............................ 98

Quadro 16 - Contexto de uso para o salão de estudos .................................................... 106 


\section{LISTA DE GRÁFICOS}

Gráfico 1 - Expansão da Rede Federal de Educação Profissional, Científica e Tecnológica em unidades 32

Gráfico 2 - Quantidade de Municípios atendidos com a expansão da Rede Federal de

Educação Profissional, Científica e Tecnológica 32

Gráfico 3 - Tipologia de Biblioteca 46

Gráfico 4 - Tipologia de cursos 76

Gráfico 5 - Modalidades desdobradas.

Gráfico 6 - Vínculo da comunidade com o IFSP 100

Gráfico 7 - Identificação de categoria de cursos. 101

Gráfico 8 - Utilização da biblioteca 103

Gráfico 9 - Uso do salão da biblioteca. 104

Gráfico 10 - Finalidade de uso do acervo 107

Gráfico 11 - Finalidade de uso do acervo dividido por categorias de usuários 108

Gráfico 12 - Tipo de material procurado 109

Gráfico 13 - Tipo de material procurado dividido por categorias de usuários . 110

Gráfico 14 - Localização de material 114

Gráfico 15 - Localização de material dividido por categorias de usuários 114

Gráfico 16 - Localização de livros indicados na bibliografia 116

Gráfico 17 - Comportamento do usuário. 118

Gráfico 18 - Preferência de materiais 119

Gráfico 19 - Empréstimo de livros 120

Gráfico 20 - Livros digitais da Person

Gráfico 21 - Empréstimo de revistas 122

Gráfico 22 - Portal de Revistas Científicas online do Instituto Federal São Paulo. 123 


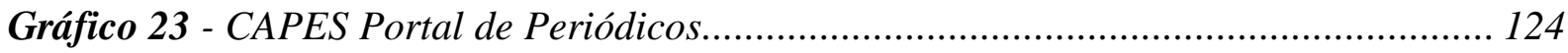

Gráfico 24 - Pergamum - Catálogo online do IFSP ........................................................ 125

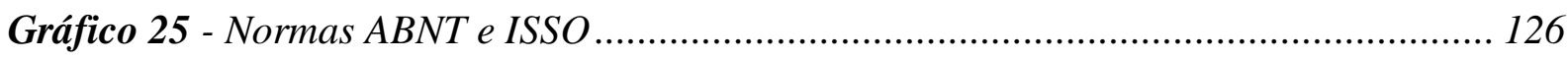

Gráfico 26 - Qualidade dos títulos disponíveis............................................................ 127

Gráfico 27 - Estado de conservação dos exemplares........................................................ 128

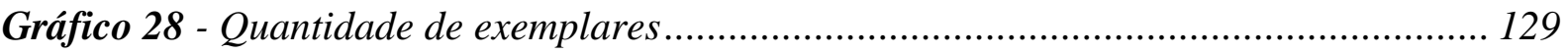




\section{LISTA DE TABELAS}

Tabela 1 - Número de matrículas dos cursos presenciais em todos os segmentos.

Tabela 2- Identificação de categoria de cursos.

Tabela 3 - Utilização da Biblioteca dividida por categorias de alunos 103

Tabela 4 - Uso do salão da Biblioteca 104

Tabela 5 - Títulos mais emprestados 111

Tabela 6 - Localização de livros indicados na bibliografia

Tabela 7 - Comportamento do usuário.

Tabela 8 - Preferência de materiais dividida por categorias de usuários

Tabela 9 - Empréstimo de livros

Tabela 10 - Livros digitais da Person

Tabela 11 - Empréstimo de revistas

Tabela 12 - Portal de Revistas Científicas online do Instituto Federal São Paulo. 123

Tabela 13 - Portal de Periódicos Capes

Tabela 14 - Pergamum - Catálogo online do IFSP.

Tabela 15 - Normas ABNT e ISO 126

Tabela 16 - Qualidade dos títulos disponíveis dividida por categoria de usuários. 127

Tabela 17 - Estado de conservação dos exemplares dividido por categorias 128

Tabela 18 - Quantidade de exemplares 129 


\section{LISTA DE ABREVIATURAS E SIGLA}

ABNT Associação Brasileira de Normas Técnicas

ASC Assessoria de Comunicação

BDTD Biblioteca Digital Brasileira de Teses e Dissertações

CAPES Coordenação de Aperfeiçoamento de Pessoal de Nível Superior

CBBI Comissão Brasileira de Bibliotecas da RFEPCT

CEFET Centro Federal de Educação Tecnológica

CONCAM Conselho de Campus

CONEPT Congresso de Educação Profissional e Tecnológica do IFSP

DAA Diretoria de Administração Acadêmica

DCC Departamento de Construção Civil

DCM Departamento de Ciência e Matemática

DEL Departamento de Elétrica

DIT Departamento de Informática e Turismo

DHU Departamento de Humanidades

DME Departamento Mecânica

EAF Escolas Agrotécnicas Federais

EIT Escola Industriais e Técnicas

EJA Educação de Jovens e Adultos

E-SIC Sistema Eletrônico do serviço de Informação ao Cidadão

ETF Escolas Técnicas Federais

IF Instituto Federal de Educação, Ciência e Tecnologia

IFSP Instituto Federal de Educação, Ciência e Tecnologia de São Paulo

MEC Ministério da Educação

NEABI Núcleo de Estudos Afro-brasileiros e Indígena 
PARFOR Plano Nacional de Formação de Professores

PDI Plano de Desenvolvimento Institucional

PIBIC Programa Institucional de Bolsas de Iniciação Científica

PRE Pró-reitora de Ensino

RFEPCT Rede Federal de Educação Profissional, Científica e Tecnológica

SRI Serviço de Referência e informação

SUAP Sistema Unificado de Administração Pública

TIC Tecnologias da Informação e Comunicação

UNED's Unidades de Ensino Descentralizadas

USP Universidade de São Paulo 
INTRODUÇÃO

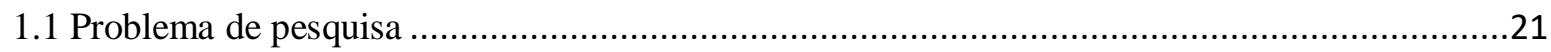

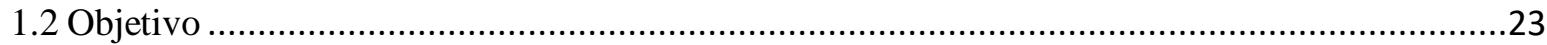

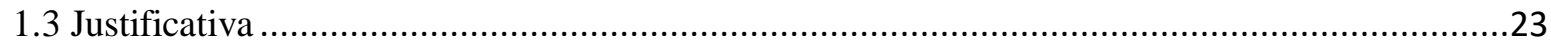

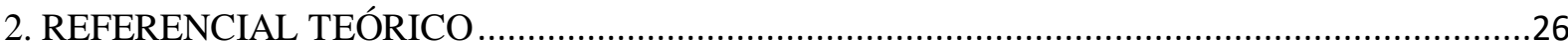

2.1 O Instituto Federal de Educação, Ciência e Tecnologia - história ...........................................26

2.1.1 O Instituto Federal de Educação, Ciência e Tecnologia - bibliotecas .....................................41

2.1.2 Biblioteca Francisco Montojos - campus São Paulo ........................................................50

2.2 Formação e desenvolvimento de coleções .......................................................................53

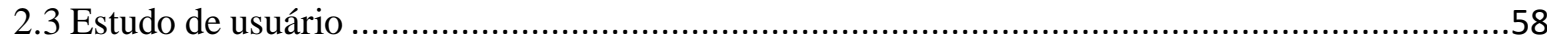

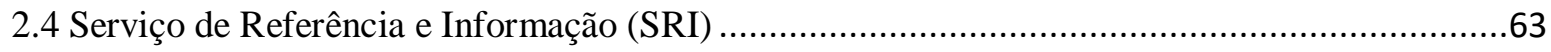

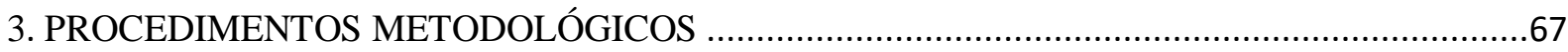

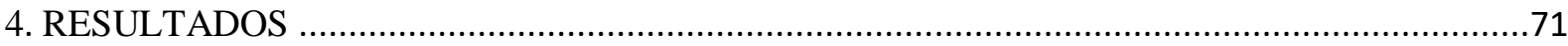

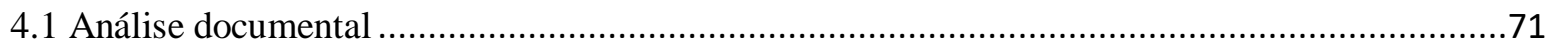

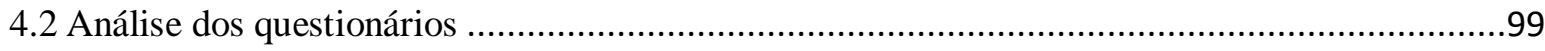

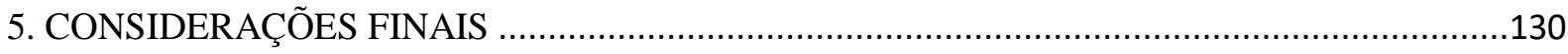

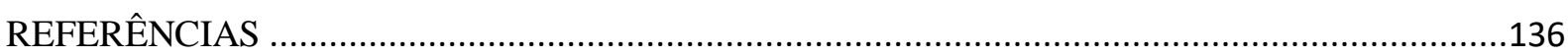

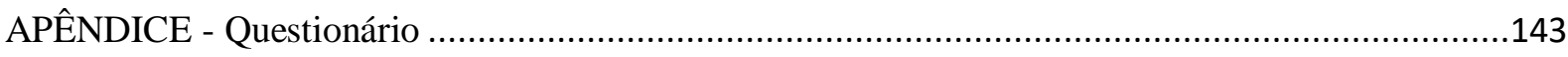

ANEXO - POLÍTICA DE DESENVOLVIMENTO DE COLEÇÕES DAS BIBLIOTECAS DO IFSP 


\section{INTRODUÇÃO}

Em dezembro de 2008, equipamentos educacionais federais com diferentes missões se converteram no Instituto Federal de Educação, Ciência e Tecnologia (IF), compondo um sistema nacional de ensino, de acordo com discussões previstas no Decreto Federal $\mathrm{n}^{\mathbf{o}}$ 6.095/2007, de 24 de abril de 2007, que estabeleceu diretrizes para o processo de integração de instituições federais e implementação dos IF no âmbito da Rede Federal de Educação Tecnológica (BRASIL, 2007).

A Lei Federal $n^{\circ} 11.892$, de 29 de dezembro de 2008, "institui a Rede Federal de Educação Profissional, Científica e Tecnológica, cria os Institutos Federais de Educação, Ciência e Tecnologia, e dá outras providências" (BRASIL, 2008). Essa legislação descreve que os Institutos Federais foram constituídos para serem autarquias, instituições independentes - de maneira similar às universidades -, centros de excelência em Ciência e Tecnologia focados em atender a demanda profissional na região em que atuam. Além disso, oferecem cursos de curta duração, ensino médio e uma variedade de cursos tecnológicos, graduações, licenciaturas, especializações, mestrados acadêmicos, profissionais e doutorados em um mesmo ambiente, com o compromisso de atender $50 \%$ de cursos técnicos e $20 \%$ de licenciaturas em cada instituição em âmbito nacional (BRASIL, 2008).

O Instituto Federal de Educação, Ciência e Tecnologia de São Paulo (IFSP) carrega toda a história dos 108 anos de ensino técnico, profissional e tecnológico no Brasil por ter sido uma das primeiras Escolas de Aprendizes Artífices ${ }^{1}$ instaladas no país - a primeira no Estado de São Paulo. Nos últimos vinte anos, passou por expansão de unidades e cursos sem precedentes, principalmente a partir de 2002, enquanto ainda se chamava Centro Federal de Educação

\footnotetext{
${ }^{1}$ Oficialmente, o ensino profissional iniciou a partir das Escolas de Aprendizes Artífices, estabelecidas por meio do Decreto $\mathrm{n}^{\circ}$ 7.566, de 23 de setembro de 1909, do presidente Nilo Peçanha, que instituiu dezenove unidades. Essas escolas localizavam-se em grandes cidades e introduziram qualificações técnicas com a finalidade de "habilitar os filhos dos desfavorecidos da fortuna com preparo técnico e intelectual e transmitir-lhes hábitos de trabalho que os afastasse da ociosidade, formando cidadãos úteis" (RIBEIRO, 1986, p. 122).
} 
Tecnológica (Cefet), aumentando de 10 para 32 campis, com mais 5 campi avançados, 1 Centro de Referência e 26 polos de Educação a Distância (Rede e-TEC Brasil). O campus São Paulo, que oferecia menos de uma dezena de cursos técnicos e superiores, hoje disponibiliza mais de 32 cursos do ensino médio ao mestrado.

Diante de um cenário de mudanças institucionais internas e externas, as bibliotecas do IFSP também foram repensadas, passando a oferecer novos produtos e serviços. Com base nisso, e definindo como objeto de estudo a Biblioteca Francisco Montojos, do campus São Paulo do IFSP, levantamos a seguinte questão: a comunidade acadêmica do IFSP - Campus São Paulo assimilou as mudanças no acervo e nos serviços relacionados oferecidos pela Biblioteca Francisco Montojos?

Por comunidade acadêmica, entende-se discentes de todos os cursos - sejam eles de nível médio, técnico ou superior (incluindo pós-graduação) -, docentes, servidores técnicoadministrativos e funcionários de empresas terceirizadas. Essa comunidade, com comportamentos e necessidades de informações distintas, constitui o público em potencial da Biblioteca Francisco Montojos.

Para analisar esse contexto, faremos um estudo de caso da Biblioteca, tendo como objetivo relacionar a missão do IFSP à Política de Desenvolvimento de Coleções das Bibliotecas do IFSP e à percepção dos usuários sobre os serviços oferecidos pela Francisco Montojos.

A metodologia é de natureza descritivo-exploratória, com análise documental do Plano de Desenvolvimento Institucional (PDI) 2014-2018 do IFSP e da Política de Desenvolvimento de Coleções das Bibliotecas do IFSP e análise dos questionários aplicados à comunidade do campus São Paulo.

Este trabalho adota a seguinte disposição: o Capítulo 1 descreve a história do IFSP, sua estrutura institucional, as bibliotecas em rede e, dentro dessa organização, a Biblioteca 
Francisco Montojos; o Capítulo 2 apresenta os pressupostos teóricos; o Capítulo 3 os procedimentos metodológicos; o Capítulo 4 os resultados; e o Capítulo 5 as considerações finais.

\subsection{Problema De Pesquisa}

Desde 2008, a antiga Escola de Aprendizes Artífices de São Paulo é uma unidade da rede do IFSP, que faz parte da Rede Federal de Educação Profissional, Científica e Tecnológica (RFEPCT).

De acordo com Pacheco (2011, p. 26), os IF são a idealização de um modelo sem cisão entre ciência/tecnologia e teoria/prática.

O fazer pedagógico desses institutos, ao trabalhar na superação da separação ciência/tecnologia e teoria/prática, na pesquisa como princípio educativo e científico, nas ações de extensão como forma de diálogo permanente com a sociedade, revela sua decisão de romper com um formato consagrado, por séculos, de lidar com o conhecimento de forma fragmentada.

Como instituição singular, os IF foram idealizados para que, além do ingresso por meio de avaliações próprias dos cursos, os discentes criem vínculos institucionais, ingressando nas instituições no ensino médio e continuando a formação até o maior grau acadêmico ofertado.

Esse novo modelo educacional foi oficializado em 2008, mas, já em 2005, o governo delineara uma vertiginosa expansão da RFEPCT, com o planejamento da expansão de infraestrutura dos IF.

Como consequência da expansão realizada a partir de 2005 e continuada no governo de Dilma Rousseff até 2016, a rede do IF no estado de São Paulo é constituída por 32 campi, 5 campi avançados, 1 Centro de Referência e 26 polos de Educação a Distância (Rede e-TEC Brasil). 
Outra consequência da expansão é o oferecimento de muitos cursos. Atualmente, o campus São Paulo abriga cursos de ensino médio profissionalizante, tecnologia, licenciatura, graduação, especialização, mestrado acadêmico e profissional, além de cursos de curta duração, perfazendo o total de cerca de 6 mil alunos atendidos - subtraídas as evasões oficiais e não oficiais.

O campus São Paulo concentra pelo menos três vezes mais cursos que as demais unidades do IFSP. Da mesma forma, possui três vezes mais discentes, docentes, servidores técnico-administrativos e funcionários de empresas terceirizadas (vigias, auxiliares de limpeza, jardineiros, eletricistas e pedreiros).

Para atender essa demanda heterogênea, a Biblioteca Francisco Montojos

tem a finalidade de oferecer suporte informacional aos programas de ensino, pesquisa e extensão e destina-se, primordialmente, a alunos regularmente matriculados em todos os níveis de ensino do Instituto, seus professores, servidores e a comunidade em geral para consultas in $\operatorname{loco}^{2}$.

Embora o campus São Paulo seja a unidade mais antiga ${ }^{3}$, a maior parte do acervo de materiais bibliográficos se constituiu na década de 2000 e é composta, dentro das especificidades dos cursos, por indicações das diretorias, baseadas no Projeto Pedagógico de Curso (PPC), e, nas indicações de assuntos e literatura em geral, por profissionais de biblioteca. A Francisco Montojos apresenta por volta de 30 mil exemplares de materiais bibliográficos diversos entre livros, periódicos, trabalhos de conclusão de curso e dissertações, além de oferecer, em rede com as demais unidades do IFSP, assinatura de livros e revistas digitais, periódicos CAPES, Normas ABNT e ISO, entre outros materiais.

Diante desse cenário, tendo em vista as mudanças ocorridas a partir de 2008, as quais alteraram, também, a configuração da Biblioteca, seu acervo e serviços relacionados,

\footnotetext{
${ }^{2}$ https://spo.ifsp.edu.br/biblioteca?id=180

${ }^{3}$ A Escola de Aprendizes Artífices de São Paulo foi a primeira entre as 19 escolas inauguradas. Fonte: https://spo.ifsp.edu.br/historico
} 
precisamos entender se os diferentes usuários assimilaram essas mudanças e se fazem uso desses serviços.

\subsection{OBJETIVo}

\section{Objetivo Geral}

Relacionar a Política de Desenvolvimento de Coleções institucional com à missão do Instituto Federal de Educação, Ciência e Tecnologia de São Paulo (IFSP) e à percepção dos usuários sobre os serviços oferecidos pela Biblioteca Francisco Montojos.

Objetivos específicos

- Analisar os princípios que regem o PDI 2014-2018 do IFSP cotejado à missão da Biblioteca Francisco Montojos,

- Examinar a Política de Desenvolvimento de Coleções das Bibliotecas do IFSP e sua compatibilidade com a missão institucional da Biblioteca Francisco Montojos e a política institucional do IFSP.

- Identificar quais serviços oferecidos pela Biblioteca são percebidos pelos usuários como subsídio para sua necessidade de informação.

\subsection{JUSTIFICATIVA}

Como os IF são entidades novas, de formato inédito, têm sido objeto de pesquisadores da Biblioteconomia, o que favoreceu, por todo o país, o aumento da literatura sobre tipologia de biblioteca e gestão de serviços informacionais para esse formato institucional. Da mesma forma, a presente pesquisa visa colaborar para a readequação e melhoria dos serviços oferecidos pela Biblioteca Francisco Montojos a partir da análise e reflexão sobre políticas de desenvolvimento de acervo e práticas implementadas. 
Antes de discutirmos a biblioteca é importante situar a instituição ao longo de sua trajetória. O campus São Paulo carrega a história de 108 anos do ensino profissional nacional, mesmo que oficialmente tenha 10 anos, conforme a Lei $\mathrm{n}^{\circ}$ 11.892, de 29 de dezembro de 2008, que o tornou uma unidade da rede de São Paulo.

A Biblioteca Francisco Montojos, que atendia usuários homogêneos com necessidades informacionais dentro do contexto do ensino médio e técnico, com o advento da expansão de cursos no IFSP, passou a acolher públicos de diferentes graus, além de servidores, funcionários das empresas terceirizadas e docentes.

Diante do fato da política institucional da unidade considerar a Biblioteca a partir do acervo apontado nos Projetos Pedagógicos de Curso (PPC), com o objetivo de atingir o conceito 5 nos instrumentos de avaliação de autorização ou reconhecimento de curso do Ministério de Educação (MEC), acreditava-se que realizar a aquisição por compra com o intuito de utilizar os materiais nas bibliografias dos cursos tornava a Biblioteca um lugar de excelência. Assim, o investimento para aquisição do acervo foi tratado como prioridade no campus São Paulo. Entretanto, os esforços foram concentrados tão somente no crescimento do acervo, ignorando a infraestrutura precária, o que impossibilita a prestação de serviços com qualidade.

Todas essas mudanças juntam-se a uma adversidade recorrente nos serviços públicos: a carência de profissionais de biblioteca. As outras bibliotecas da rede são compostas por dois bibliotecários e, às vezes, dois auxiliares de biblioteca. A partir de 2013, o campus São Paulo formou a equipe de cinco bibliotecários, três auxiliares de biblioteca e um assistente administrativo, devido à larga expansão de cursos, mas a equipe ainda se encontra em número insuficiente para atender tantas demandas.

Com o passar do tempo, a nova configuração dos trabalhos em rede no IFSP permitiu a construção de documentos comuns, a aquisição do sistema integrado de Bibliotecas Pergamum, 
a assinatura da Biblioteca Virtual, da editora Pearson, das Normas da ABNT e Isso, entre outros serviços.

A Biblioteca Francisco Montojos foi a escolhida, tendo em vista o tamanho de seu acervo, e, também, o fato do campus São Paulo abrigar a maior quantidade de cursos, usuários e profissionais entre as unidades do IFSP. Nesse contexto, percebe-se a necessidade deste estudo para subsidiar uma futura reestruturação de serviços compatíveis com a diversidade dessa comunidade acadêmica. 


\section{REFERENCIAL TEÓRICO}

Inicialmente, este estudo apresenta o histórico institucional desde as Escolas de Aprendizes Artífices em 1909 até a estrutura atual do campus São Paulo do IFSP. Em seguida, traz a organização das bibliotecas em geral dos IF e, mais especificamente, das bibliotecas do IFSP. Dentro desse contexto, a subdivisão Biblioteca Francisco Montojos do campus São Paulo do IFSP expõe as particularidades da unidade informacional e sua comunidade acadêmica

Todo o conteúdo apresentado sobre os IF neste trabalho traz elementos que são analisados pela perspectiva do referencial teórico da Ciência da Informação: Formação e Desenvolvimento de Coleções, do Estudo de Caso e do Serviço de Referência e Informação (SRI).

\subsection{O Instituto Federal de EduCAÇão, Cî̂nCIA E Tecnologia - história}

Antes da denominação "Instituto Federal de Educação, Ciência e Tecnologia", essas instituições passaram por múltiplas nomenclaturas e tiveram diferentes missões, que foram mudando ao longo do tempo, como podemos verificar na Figura 1, com a linha do tempo do ensino profissional federal. 
Figura 1 - Linha do tempo do ensino profissional federal

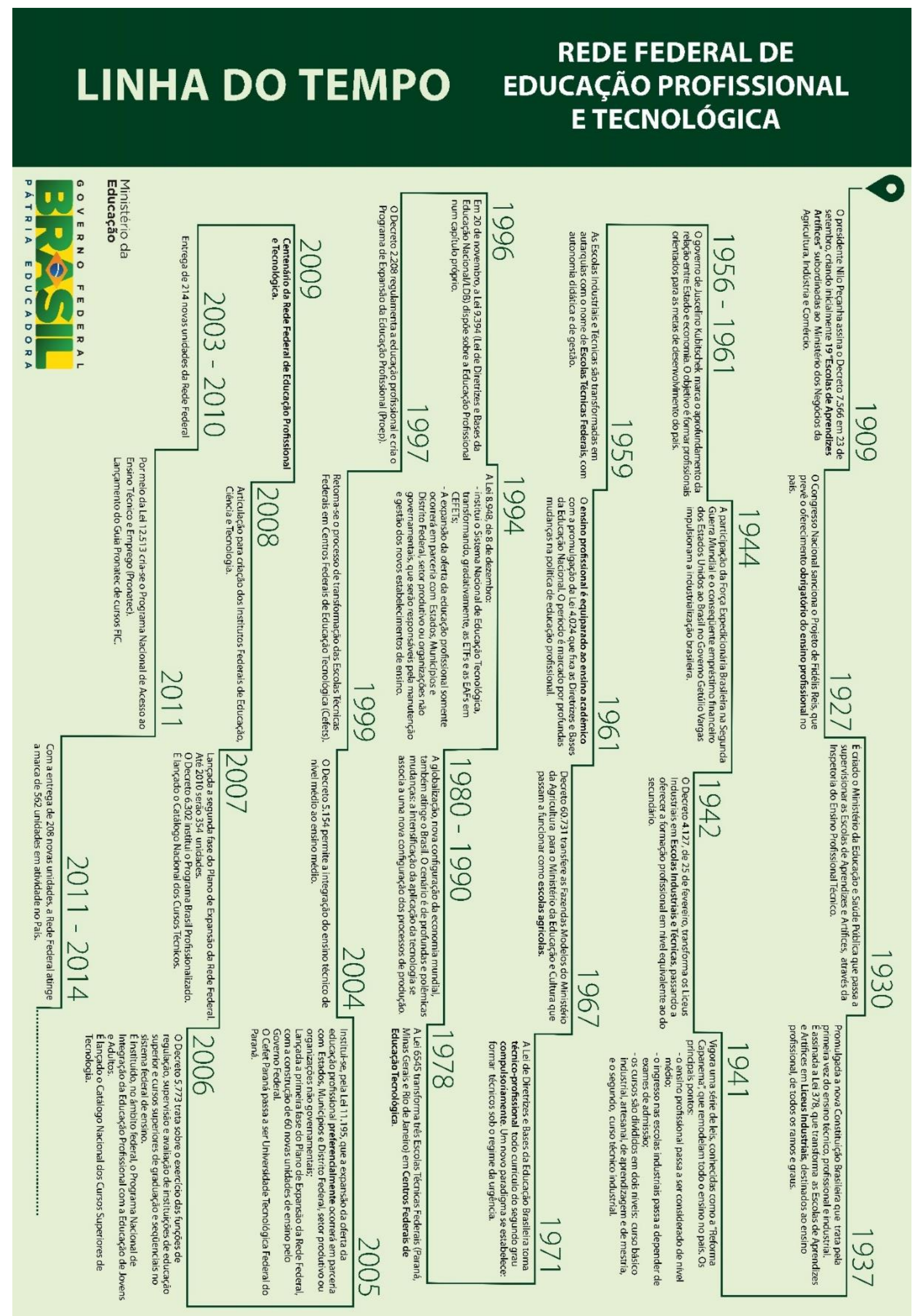


A história da educação profissional no Brasil começou no período colonial, de economia predominantemente agrícola. Embora a educação profissional tenha forte ligação com a industrialização, a princípio, o ensino estava ligado ao exercício de atividades manuais, destinadas ao público de classes mais baixas. À elite, reservava-se a educação acadêmica, propedêutica e continuada. A industrialização era incipiente, e, com a chegada da família real e a revogação da proibição da existência de fábricas no país, em voga desde 1785, várias escolas profissionais foram criadas.

Entretanto, mesmo diante de diversos exemplos de escolas profissionais anteriores, considera-se, oficialmente, que o marco inicial do ensino profissional foi o Decreto $\mathrm{n}^{\mathrm{o}} 7.566$, de 23 de setembro de 1909, do presidente Nilo Peçanha, que instituiu dezenove Escolas de Aprendizes Artífices. Essas escolas localizavam-se em grandes cidades e introduziram qualificações técnicas, com a finalidade de "habilitar os filhos dos desfavorecidos da fortuna com preparo técnico e intelectual e transmitir-lhes hábitos de trabalho que os afastasse da ociosidade, formando cidadãos úteis" (RIBEIRO, 1986, p. 122).

Tendo em vista a economia predominantemente agrícola, a recente extinção da escravidão e a intensa imigração, essas escolas exerciam "um processo de formação do operário cidadão, cônscio de seus deveres e direitos e cumpridor de suas obrigações morais e sociais" (D’ANGELO, 2000, p. 9).

Ao promover o início da formação do operário médio para suprir a industrialização em meio à hegemonia agrícola, na verdade, o governo aspirava controlar a ordem "moldando" o operário-cidadão. D’Angelo (2000) relata o medo que a aristocracia sentia das multidões que começaram a se aglomerar nas grandes cidades e que o governo estudava uma alternativa à repressão policial para as práticas de “vadiagem”. Assim, a elite, representada pelo Estado, intencionava controlar o trabalhador "moldando o cidadão-modelo de forma civilizada [...]. 
[Acreditando que] o trabalhador estrangeiro com tradição e cultura diversa [poderia] seguir os ‘cidadãos’ moldados no espírito da brasilidade” (D’ANGELO, 2000, p. 10).

A Escola de Aprendizes Artífices de São Paulo iniciou suas atividades no ano de 1910. Em, 1937, passou a denominar-se Liceu Industrial de São Paulo, estabelecido na Lei Federal no 378, do mesmo ano. A Constituição assinada por Getúlio Vargas em 1937 estimulava o crescimento industrial e, por isso, os Liceus se tornaram um elemento estratégico para a formação de mão de obra qualificada para abastecer as novas demandas.

Em 1947, o Decreto Federal n 4.127 instaurou a Escola Industrial e Técnica (EIT), depois de uma reforma no ensino que equiparava o ensino profissional e técnico ao ensino médio. Em 1959, surge a Escola Técnica Federal (ETF), com autonomia administrativa e pedagógica, outorgada pela Lei Federal no 3.552. As ETFs eram consideradas essenciais para a expansão industrial, por serem baseadas em um modelo internacional, de países industrializados, que requeria qualificações mais especializadas.

De acordo com D'Angelo (2007), a partir dos anos 1960, ocorreu uma ruptura com a visão institucional inicial de servir aos mais carentes, pois as ETFs passaram a ofertar, além do ensino profissional, conhecimentos gerais. Diante disso, a classe média constatou que a formação profissional não se encerrava no ensino técnico e profissional, pois esse novo modelo educacional oferecia estudos sólidos, que possibilitavam o ingresso em universidades públicas.

As ETFs, que, ao longo do tempo, foram reconhecidas como centros de excelência em educação profissional, tornaram-se um dos principais polos geradores de estudantes aprovados em vestibulares de universidades públicas, com classificações consideráveis em rankings de diferentes exames.

Em 1978, foi criado o Centro Federal de Educação Tecnológica (Cefet), que iniciou com três unidades. A instituição oferecia a formação em ensino superior de engenheiros de operação e tecnólogos, em busca de modificar e se apropriar do mercado de trabalho. Entretanto, esse 
modelo escolar não se propagou até a reforma da educação profissional, instituída por meio do Decreto Federal no 2.208, de 1997 (BRASIL, 1997b).

Nos anos 1990, uma reforma na educação profissional promoveu uma desvinculação do ensino médio integrado - ensino profissional e ensino médio.

Foi nesse contexto da separação do ensino médio integrado que surgiram os cursos técnicos concomitantes e subsequentes, mas também os cursos superiores de tecnologia e logo depois, os cursos de bacharelado e as primeiras experiências com licenciaturas. (LIMA, 2016, p. 74).

A reforma possibilitou o oferecimento de ensino médio e o surgimento do curso técnico concomitante e subsequente para estudantes que já haviam se formado no ensino médio, ou que queriam realizar, opcionalmente, o ensino médio integral. Além dessas novas modalidades, exploraram-se novas propostas, como os cursos superiores em tecnologia e as licenciaturas. Assim, os Cefets se tornaram instituições com capacidade de oferecer cursos de ensino médio, técnico, graduação, licenciatura e tecnológicos, quando constatada a necessidade da comunidade e do mercado de trabalho de profissionais técnicos e liberais com formação acadêmica de alto nível, para imprimir qualidade no ensino.

Por meio do Decreto Federal n 5.225 , de 2004, os Cefets obtiveram autonomia para criar, organizar e extinguir cursos, prerrogativa equivalente à das universidades federais. Nesse contexto, ocorre, a partir de 1999, uma expansão dos Cefets, com a absorção de parte das Escolas Agrotécnicas (EAF) e das ETFs.

De acordo com Lima (2016), até então, a Rede Federal de Educação Profissional, Científica e Tecnológica (RFEPCT) era composta por 39 Escolas Agrotécnicas Federais, 33 Centros Federais de Educação Tecnológica, 32 Escolas Técnicas vinculadas às universidades federais (EV), 1 (uma) Universidade Tecnológica e 7 Escolas Técnicas Federais (ETF).

Para estabelecer os Institutos de Educação, Ciência e Tecnologia, o governo de Luiz Inácio Lula da Silva destituiu a Medida Provisória nº 1.549/97 (BRASIL, 1997a), do governo 
de Fernando Henrique Cardoso, que, em seu Art. 44, transferia a responsabilidade de manutenção e gestão do ensino técnico para os Estados, Municípios, Distrito Federal, setor produtivo e/ou organizações não governamentais, retirando a responsabilidade da União no ensino profissionalizante.

Assim, por meio da Lei Federal n 11.892, em 29 de dezembro de 2008, os IF foram estabelecidos.

\begin{abstract}
Art. 2o Os Institutos Federais são instituições de educação superior, básica e profissional, pluricurriculares e multicampi, especializados na oferta de educação profissional e tecnológica nas diferentes modalidades de ensino, com base na conjugação de conhecimentos técnicos e tecnológicos com as suas práticas pedagógicas, nos termos desta Lei. (BRASIL, 2008).
\end{abstract}

Os IFs foram formados pela junção de vários dos centros escolares citados acima, que formavam a RFEPCT à época, os quais, de forma voluntária, optaram por se tornarem IF. Os IFs são autarquias federais, subordinadas ao MEC e à RFEPCT.

Atualmente, a RFEPCT é composta por 2 Cefets, 1 (uma) Universidade Tecnológica, 25 escolas vinculadas às Universidades Federais e pelo Colégio Pedro II, instituições que optaram por não se converterem em IF.

De acordo com Becker e Faqueti (2015, p. 27), a reestruturação da Rede Federal de Educação Profissional exigiu mudanças radicais
em todo o ambiente organizacional das antigas Escolas Técnicas, Agrotécnicas,
UNEDs e CEFETs, que possuíam suas particularidades no oferecimento de
determinados cursos

Talvez por isso muitas escolas não optaram pela mudança. Desse modo, ainda existem Cefets no Rio de Janeiro e em Minas Gerais.

Além das escolas convertidas, ocorreu um crescimento exponencial de IFs. A RFEPCT viu sua rede de IFs saltar de 140 unidades em 2002 para mais de 400 campi em 2011. "[...] na última década, a Rede Federal mais que dobrou a oferta de matrículas da educação profissional, com um crescimento de 108\%” (INSTITUTO, 2014, p. 29). 
Gráfico 1 - Expansão da Rede Federal de Educação Profissional, Científica e Tecnológica em unidades $^{4}$

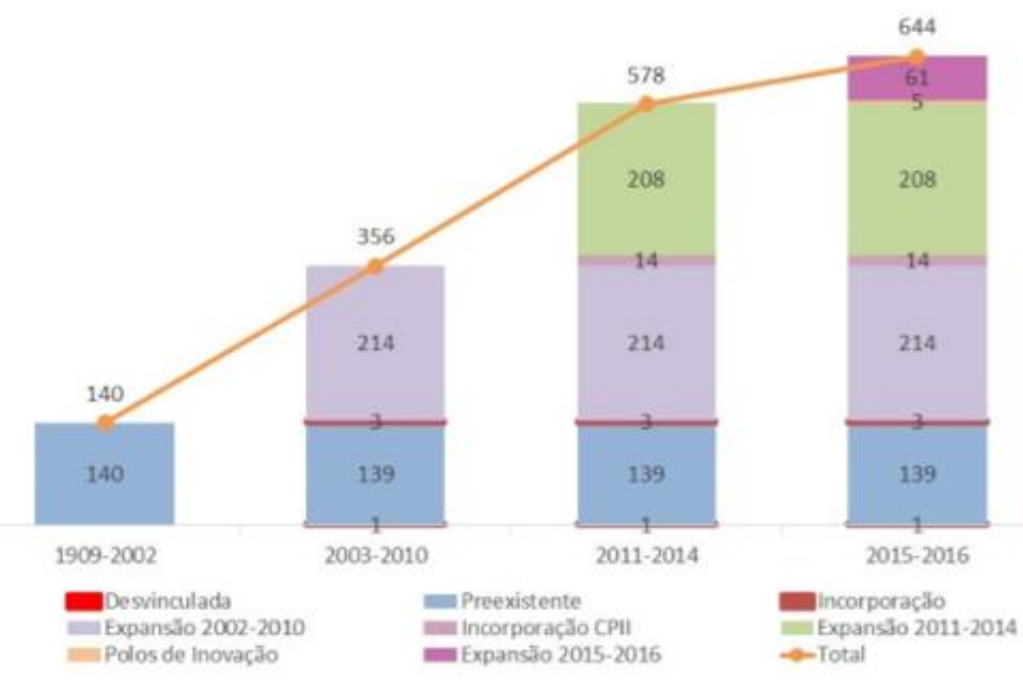

Fonte: Site MEC

Gráfico 2 - Quantidade de Municípios atendidos com a expansão da Rede Federal de Educação Profissional, Científica e Tecnológica 5

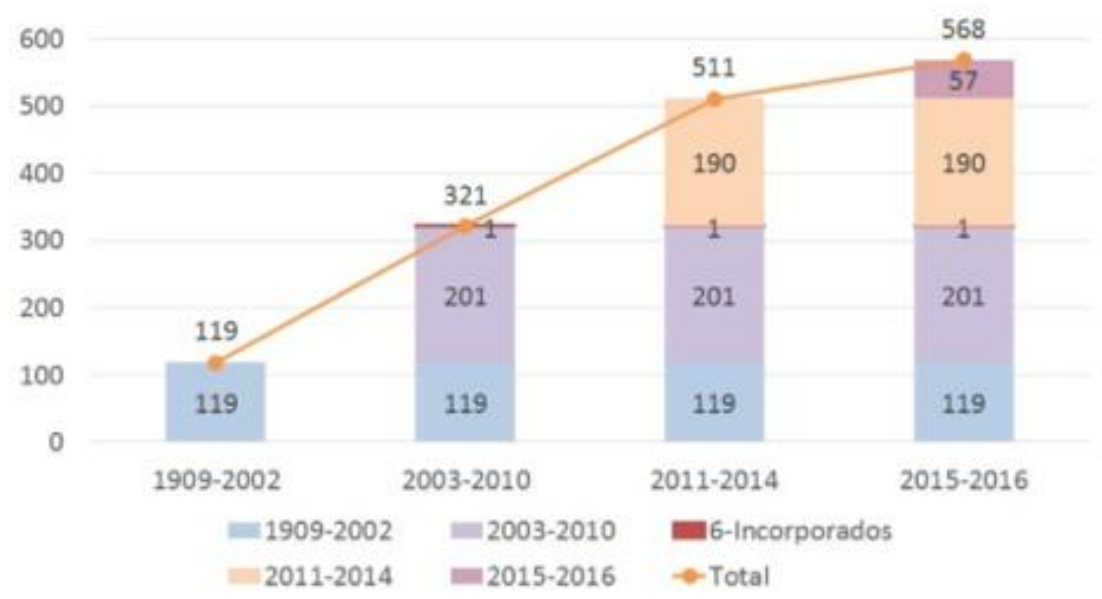

Fonte: Site MEC

${ }^{4}$ Fonte: Site Rede Federal de Educação Profissional, Científica e Tecnológica. Disponível em: < http://redefederal.mec.gov.br/expansao-da-rede-federal>. Gráficos publicados: Quarta, 02 de Março de 2016, $11 \mathrm{~h} 41$

5 Fonte: Site Rede Federal de Educação Profissional, Científica e Tecnológica. Disponível em: < http://redefederal.mec.gov.br/expansao-da-rede-federal>. Gráficos publicados: Quarta, 02 de Março de 2016, $11 \mathrm{~h} 41$ 
Nos primeiros anos de expansão, todas as prefeituras que demonstraram interesse e cederam terrenos prontos para construção ou prédios para serem adaptados tiveram êxito, pois o IF, juntamente com o MEC, possibilitava a inclusão das unidades na Rede. Para cuidar da infraestrutura e dos demais recursos, os IFs promoveram equipes próprias nas reitorias, com poder de pró-reitoria para administrar a propagação das unidades.

Quadro 1 - Expansão dos Institutos Federais em 3 fases

\begin{tabular}{|c|c|}
\hline FASE I (2005-2006) & $\begin{array}{l}\text { Criação de } 64 \text { novas unidades. } 37 \text { novas } \\
\text { UNED'S - Unidades de Ensino } \\
\text { Descentralizadas, vinculadas aos CEFET's, } 9 \\
\text { novas autarquias, e } 18 \text { novas escolas que não } \\
\text { pertenciam à Rede Federal. }\end{array}$ \\
\hline FASE II (2007-2010) & $\begin{array}{l}\text { Instalação de mais } 150 \text { novas unidades de } \\
\text { ensino. Somando às } 64 \text { unidades criadas na } \\
\text { fase I, contabilizava-se } 214 \text { novas unidades, } \\
\text { que somadas as } 140 \text { já existentes, } \\
\text { totalizavam } 354 \text { (MEC/SETE/C2010). }\end{array}$ \\
\hline FASE III (2011-2020) & $\begin{array}{l}\text { Implantação de } 86 \text { novos campi de Instituto } \\
\text { Federal, dos quais } 46 \text { remanescentes da Fase } \\
\text { II. Segundo este documento, o prazo para } \\
\text { a implantação destes campi era dezembro de } \\
2011 \text {. Segundo o site da SETEC, até } 2014 \\
\text { serão } 562 \text { unidades, oportunizando } 600 \text { mil } \\
\text { vagas em todo o Brasil. }\end{array}$ \\
\hline
\end{tabular}

Fonte: Site Rede Federal de Educação Profissional, Científica e Tecnológica

A seguir, o último mapa divulgado pela Rede (2016) sobre a presença dos IFs nos estados brasileiros. 
Figura 2 - Apontamento de unidades dos Institutos Federais

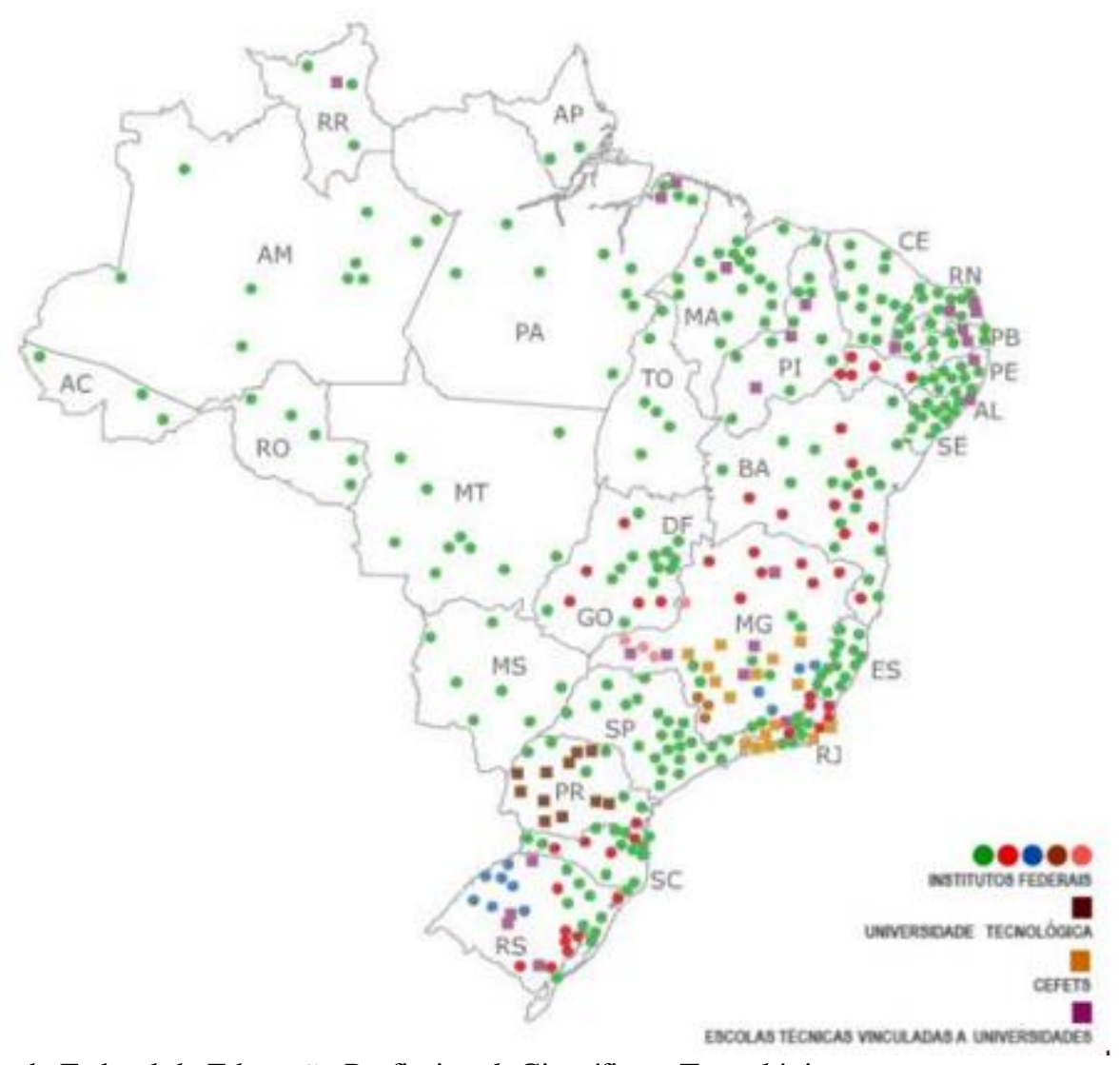

Fonte: Site Rede Federal de Educação Profissional, Científica e Tecnológica

Atualmente, existem 38 IFs em todos os estados brasileiros (mais de um IF em alguns estados) e mais de 562 campi em funcionamento - nas modalidades campus, campus avançado e Centros de Referência (MEC, 2018).

Para melhor entendimento: os campi são definidos como unidades dentro da rede; os Centros de Referência têm o objetivo de oferecer capacitação pedagógica aos professores da rede pública de ensino; e os campi avançados se concentram em ensino e extensão, limitandose a áreas específicas ou temáticas, ou seja, são extensões vinculadas a campi já existentes, ou, em caráter excecional, a reitorias.

Os IFs são considerados entidades inéditas por atuarem em diversos níveis. Assim "essas instituições têm suas bases em um conceito de educação profissional e tecnológica sem similar em nenhum outro país." (PACHECO, 2011).

Conforme Becker (2015, p. 27): 
A oferta diversificada de ensino, desde a formação inicial e continuada de trabalhadores até as pós-graduações, confere às instituições da RFEPCT uma natureza singular, uma vez que normalmente as estruturas educacionais do país, públicas ou privadas, não atendem numa abrangência desta magnitude.

Os IFs são pautados no desenvolvimento da Ciência e Tecnologia, com intenção de integrar o ensino técnico e científico, vinculando pesquisa, ensino e extensão por meio de intervenção na região de atuação.

A estrutura multicampi e a clara definição do território de abrangência das ações dos Institutos Federais afirmam, na missão dessas instituições, o compromisso de intervenção em suas respectivas regiões, identificando problemas e criando soluções técnicas e tecnológicas para o desenvolvimento sustentável com inclusão social. Na busca de sintonia com as potencialidades de desenvolvimento regional, os cursos nas novas unidades deverão ser definidos por meio de audiências públicas e da escuta às representações da sociedade. (PACHECO, 2011, p. 14)

Assim sendo, os cursos são escolhidos a partir do perfil político, cultural e socioeconômico da localidade na qual a unidade está inserida, com a participação da sociedade civil do entorno. Segundo Pacheco (2011, p. 22), a intervenção dos IFs "deve explorar as potencialidades de desenvolvimento, a vocação produtiva de seu lócus; a geração e transferência de tecnologias e conhecimentos e a inserção, nesse espaço, da mão de obra qualificada".

Nessa conjuntura, os IFs têm a missão de destinar 50\% das vagas para os cursos técnicos - em sua maioria, na forma integrada com o ensino médio - e $20 \%$ para as licenciaturas e graduações tecnológicas, "podendo ainda disponibilizar especializações, mestrados profissionais e doutorados voltados principalmente para a pesquisa aplicada de inovação tecnológica".

Assim como nas demais entidades, os campi do IFSP são unidades independentes, com diretores eleitos a cada quatro anos. Todos esses campi, inclusive os campi avançados, são vinculados à Reitoria no que tange a questões legais e de orçamento, e se concentram em ensino, extensão e na área de Ciências, conforme os objetivos estabelecidos na Lei n ${ }^{\circ} 11.892$, Art. $6^{\circ}$, Inciso V: "constituir-se em centro de excelência na oferta do ensino de ciências". 
Conforme se verifica no Quadro 2, a expansão do IFSP iniciou-se antes da instituição ter esse nome, mas diferentemente das datas apontadas no Quadro 1, que retrata a Fase 1 da expansão. Das três unidades mais antigas, a mais recente era dos anos 1990. A primeira fase da expansão ocorreu a partir da década de 2000, quando mais sete unidades foram inseridas enquanto a escola era Cefet.

Quadro 2 - Unidades implantadas até agosto de 2008

\begin{tabular}{|c|c|c|}
\hline Unidade & Autorização de Funcionamento & $\begin{array}{l}\text { Início das } \\
\text { Atividades }\end{array}$ \\
\hline São Paulo & Decreto 7.566 , de $23 / 9 / 1909$ & $24 / 2 / 1910$ \\
\hline Cubatão & Portaria Ministerial 158, de 12/03/1987 & $01 / 4 / 1987$ \\
\hline Sertãozinho & Portaria Ministerial 403, de 30/04/1996 & Janeiro/1996 \\
\hline Guarulhos & $\begin{array}{l}\text { Portaria Ministerial 2.113, de } \\
06 / 06 / 2006\end{array}$ & $13 / 2 / 2006$ \\
\hline $\begin{array}{l}\text { Bragança } \\
\text { Paulista }\end{array}$ & $\begin{array}{l}\begin{array}{l}\text { Portaria Ministerial } 1.712, \\
20 / 10 / 2006\end{array}\end{array}$ & $30 / 07 / 2007$ \\
\hline Salto & $\begin{array}{l}\text { Portaria Ministerial } 1.713, \text { de } \\
20 / 10 / 2006\end{array}$ & $02 / 08 / 2007$ \\
\hline Caraguatatuba & $\begin{array}{l}\text { Portaria Ministerial } 1.714, \quad \text { de } \\
20 / 10 / 2006\end{array}$ & $12 / 2 / 2007$ \\
\hline $\begin{array}{l}\text { S. João da B. } \\
\text { Vista }\end{array}$ & $\begin{array}{l}\text { Portaria Ministerial } 1.715, \text { de } \\
20 / 10 / 2006\end{array}$ & $02 / 01 / 2007$ \\
\hline São Roque & Portaria Ministerial 710 , de 09/06/2008 & $11 / 08 / 2008$ \\
\hline São Carlos & $\begin{array}{l}\text { Portaria Ministerial } 1.008, \text { de } \\
29 / 10 / 2007\end{array}$ & $01 / 08 / 2008$ \\
\hline
\end{tabular}

Fonte: Diário Oficial da União

Depois da expansão inicial, quando a escola se tornou IFSP, em 2008, curiosamente, a data da Fase 2, descrita no Quadro 1, coincide com o final do segundo mandato do então presidente Luiz Inácio Lula da Silva, em 2010. Na Fase 2, foram criadas mais dez unidades, conforme se verifica no Quadro 2. 
A Fase 3, descrita no Quadro 1, ocorre no primeiro mandato de Dilma Rousseff, quando são instaladas mais seis unidades.

Quadro 3 - Unidades implantadas até setembro de 2013

\begin{tabular}{|c|c|c|}
\hline Campus & Autorização de Funcionamento & $\begin{array}{l}\text { Inicio das } \\
\text { Atividades }\end{array}$ \\
\hline $\begin{array}{l}\text { Campos do } \\
\text { Jordão }\end{array}$ & Portaria Ministerial no. 116 , de 29/01/2010 & $02 / 2009$ \\
\hline Birigui & Portaria Ministerial no. 116 , de 29/01/2010 & $2^{\circ}$ semestre de 2010 \\
\hline Piracicaba & Portaria Ministerial no. 104, de 29/01/2010 & $2^{\circ}$ semestre de 2010 \\
\hline Itapetininga & Portaria Ministerial no. 127 , de $29 / 01 / 2010$ & $2^{\circ}$ semestre de 2010 \\
\hline Catanduva & Portaria Ministerial $n^{\circ} .120$, de $29 / 01 / 2010$ & $2^{\circ}$ semestre de 2010 \\
\hline Araraquara & Portaria Ministerial no 1.170 , de $21 / 09 / 2010$ & $2^{\circ}$ semestre de 2010 \\
\hline Suzano & Portaria Ministerial n 1.170 , de $21 / 09 / 2010$ & $2^{\circ}$ semestre de 2010 \\
\hline Barretos & Portaria Ministerial no 1.170 , de $21 / 09 / 2010$ & $2^{\circ}$ semestre de 2010 \\
\hline Boituva & Resolução no 28, de 23/12/2009 & $2^{\circ}$ semestre de 2010 \\
\hline Capivari & Resolução no 30, de 23/12/2009 & $2^{\circ}$ semestre de 2010 \\
\hline Matão & Resolução no 29, de 23/12/2009 & $2^{\circ}$ semestre de 2010 \\
\hline Avaré & Portaria Ministerial no 1.170 , de $21 / 09 / 2010$ & $1^{\circ}$ semestre de 2011 \\
\hline Hortolândia & Portaria Ministerial no 1.170 , de 21/09/2010 & $1^{\circ}$ semestre de 2011 \\
\hline Votuporanga & Portaria Ministerial n 1.170 , de $21 / 09 / 2010$ & $1^{\circ}$ semestre de 2011 \\
\hline $\begin{array}{l}\text { Presidente } \\
\text { Epitácio }\end{array}$ & Portaria Ministerial no 1.170 , de $21 / 09 / 2010$ & $1^{\circ}$ semestre de 2011 \\
\hline Registro & Portaria Ministerial no 1.170 , de $21 / 09 / 2010$ & $1^{\circ}$ semestre de 2012 \\
\hline Campinas & Portaria Ministerial no 1.170 , de 21/09/2010 & $1^{\circ}$ semestre de 2012 \\
\hline
\end{tabular}

Fonte: Diário Oficial da União

Depois disso, ainda são acrescentadas as unidades de Assis (2013), Sorocaba (2014), Jundiaí (2014), Ilha Solteira (2015) e Pirituba (2016), que podem ser verificadas no mapa dos campi, apresentado na Figura 3. 
Figura 3 - Mapa dos campi $(2016)^{6}$

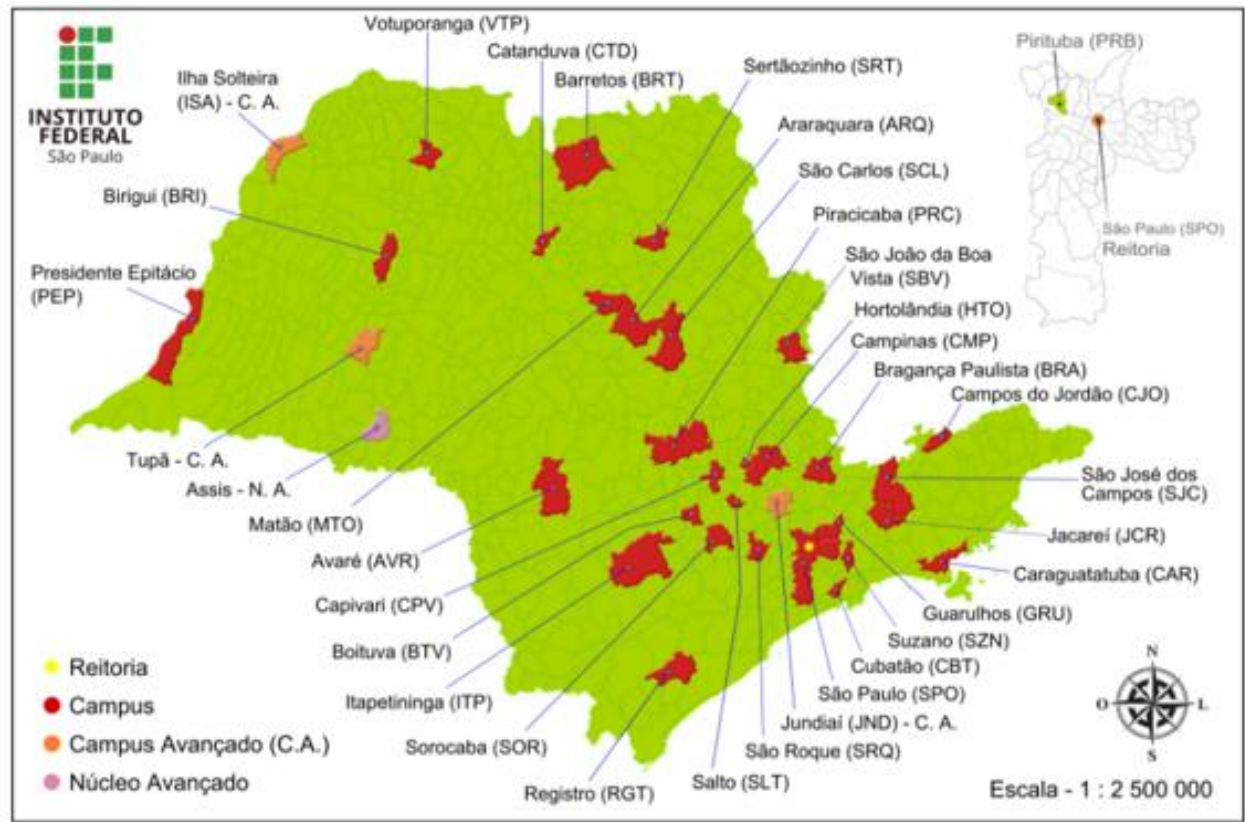

Fonte: Site do IFSP

A organização do organograma no IFSP está estruturada da seguinte maneira:

\footnotetext{
${ }^{6}$ Elaboração cartográfica: Leandro Henrique da Silva. Arte Final: Vitor Hugo de Rosa. Software Philcarto/Inkscap Fonte: SIMEC/IBGE/PRE, fevereiro 2016
} 
Figura 4 - Estrutura Organizacional do Instituto Federal de Educação, Ciência e Tecnologia de São Paulo - IFSP

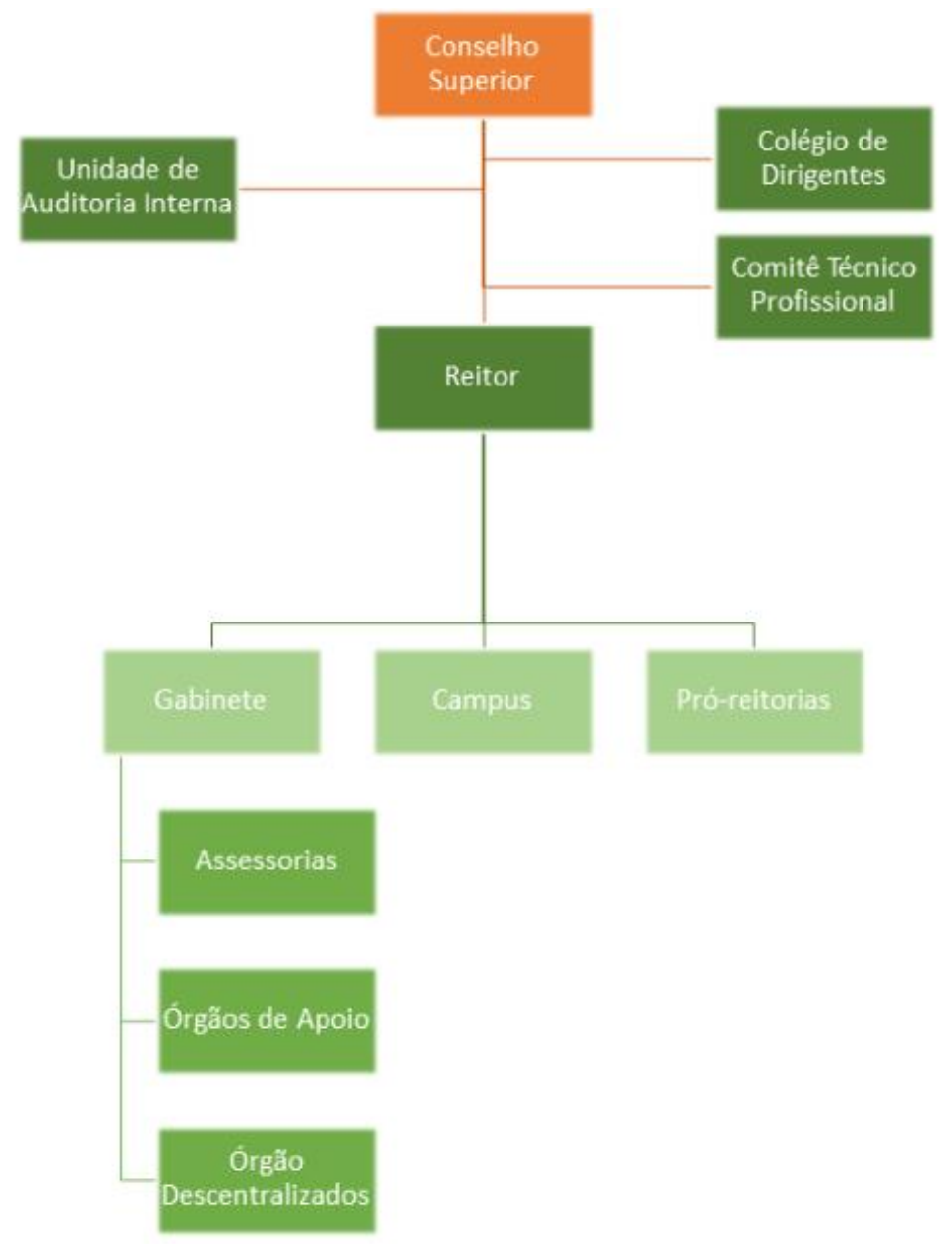

Fonte: Site IFSP

O Conselho Superior é o órgão máximo de caráter consultivo e deliberativo e segue o regulamento determinado na Resolução $n^{\circ} 1.100^{7}$, de 3 de dezembro de 2013. O órgão colegiado é presidido pelo reitor e tem a participação de todos os segmentos da comunidade acadêmica institucional, decidindo as regulamentações e diretrizes referentes à atuação acadêmica e administrativa do IFSP.

Em seguida, vem o Colégio de Dirigentes, estabelecido na Resolução Federal no $169^{8}$, de 15 de novembro de 2010. O Colégio de Dirigentes é um órgão de caráter consultivo com a

\footnotetext{
${ }^{7}$ http://www.ifsp.edu.br/index.php/arquivos/category/648-regulamento.html

${ }^{8}$ http://www.ifsp.edu.br/index.php/instituicao/colegio-de-dirigentes.html
} 
finalidade de ser um instrumento de apoio decisório nas áreas administrativas, de ensino, pesquisa e extensão, em conformidade com o planejamento do IFSP. É composto pelo reitor, na figura de presidente, pelos pró-reitores e pelos diretores dos campi.

Na sequência, temos as unidades de auditoria interna e o Comitê Técnico-Profissional ${ }^{9}$, que é um órgão de assessoramento do Conselho Superior. Logo depois, a Reitoria e o Gabinete, seguidos das pró-reitorias de Administração; de Desenvolvimento; de Ensino; de Pesquisa, Inovação e Pós-Graduação; e de Extensão. Por fim, as diretorias.

Na Figura 4, apresentamos o organograma institucional descrito anteriormente. No Quadro 4, a representação das subunidades estratégicas do IFSP.

Quadro 4 - Pró-reitora de Ensino (PRE)

\begin{tabular}{|c|c|c|c|c|}
\hline Áreas/Subunidades Estratégicas & \begin{tabular}{|l|} 
Competências \\
\end{tabular} & Titular & Cargo & Período de atuação \\
\hline Pró-reitoria de Ensino & $\begin{array}{l}\text { Propor, elaborar, atualizar e zelar pelas políticas gerais } \\
\text { do IFSP e de seu Plano de Desenvolvimento } \\
\text { Institucional. Cuidar da formulação e execução da } \\
\text { politica de ensino do IFSP, articulada com a pesquisa e } \\
\text { extensão, em consonância com as diretrizes } \\
\text { provenientes do Ministério da Educação e do Conselho } \\
\text { Superior do IFSP. }\end{array}$ & $\begin{array}{l}\text { Cynthia Regina Fischer } \\
\text { Reginaldo Vitor Pereira }\end{array}$ & Pró-reitor & $\begin{array}{l}18 / 04 / 2013 \text { a } 05 / 01 / 2015 \\
06 / 01 / 2015 \text { - Atual }\end{array}$ \\
\hline $\begin{array}{l}\text { Assessoria da Pró-reitoria de } \\
\text { Ensino }\end{array}$ & & $\begin{array}{l}\text { Clara Sihel } \\
\text { Ana Cláudia Daroz }\end{array}$ & Diretora & $\begin{array}{l}14 / 04 / 2014 \text { a } 30 / 03 / 2015 \\
31 / 03 / 2015 \text { - Atual }\end{array}$ \\
\hline $\begin{array}{l}\text { Diretoria de Administração } \\
\text { Acadêmica }\end{array}$ & $\begin{array}{l}\text { Dirigir, planejar, executar e atualizar constantemente a } \\
\text { padronização dos procedimentos relacionados à } \\
\text { Administração e às normas acadêmicas. }\end{array}$ & $\begin{array}{l}\text { Solange de Oliveira } \\
\text { Aline Gonzaga Ramos } \\
\text { Andreia Ap. Vieira Belo } \\
\text { Ferreira } \\
\end{array}$ & Diretora & $\begin{array}{l}20 / 05 / 2013 \text { a } 01 / 03 / 2015 \\
02 / 03 / 2015-25 / 09 / 2015 \\
02 / 10 / 2015 \text { - Atual } \\
\end{array}$ \\
\hline Diretoria de Educação a Distância & $\begin{array}{l}\text { Dirigir, planejar e executar ações relacionadas a } \\
\text { Educação a Distância. }\end{array}$ & $\begin{array}{l}\text { Marilene Esquiavoni } \\
\text { Paulo José Evaristo da Silva }\end{array}$ & Diretora & $\begin{array}{l}11 / 10 / 2013 \text { a } 18 / 02 / 2015 \\
25 / 02 / 2015 \text { - Atual }\end{array}$ \\
\hline Diretoria de Educação Básica & $\begin{array}{l}\text { Dirigir, planejar e executar ações relacionadas ao } \\
\text { Ensino Médio Integrado, } \\
\text { Concomitante/Subsequente e os Projetos Educacionais. }\end{array}$ & $\begin{array}{l}\text { Cláudia Abboud Aranega } \\
\text { Karina Aparecida de Freitas } \\
\text { Dias de Souza }\end{array}$ & Diretora & $\begin{array}{l}\text { 24/04/2013 a 31/03/2015 } \\
01 / 04 / 2015 \text { - Atual }\end{array}$ \\
\hline Diretoria de Graduação & $\begin{array}{l}\text { Dirigir, planejar e executar ações relacionadas às } \\
\text { Licenciaturas, Tecnologias, Bacharelados e Avaliação } \\
\text { Externa. }\end{array}$ & $\begin{array}{l}\text { Valéria Azzi Collet da Graça } \\
\text { Ana Paula Santos da } \\
\text { Conceição } \\
\end{array}$ & Diretora & $\begin{array}{l}24 / 04 / 2013 \text { a } 23 / 02 / 2015 \\
24 / 02 / 2015 \text { - Atual }\end{array}$ \\
\hline Diretoria de Projetos Especiais & $\begin{array}{l}\text { Dirigir, planejar e executar ações relacionadas à } \\
\text { Assistência Estudantil, às Normas e Supervisão } \\
\text { Pedagógica; às Ações Inclusivas e de Educação de } \\
\text { Jovens e Adultos. }\end{array}$ & $\begin{array}{l}\text { Paulo Sérgio Garcia } \\
\text { Adriana Paes de Jesus Correia }\end{array}$ & Diretor & $\begin{array}{l}23 / 05 / 2014 \text { a } 01 / 02 / 2015 \\
02 / 02 / 2015 \text { - Atual }\end{array}$ \\
\hline Diretoria de Politicas de Acesso & $\begin{array}{l}\text { Planejar e coordenar as etapas do processo seletivo de } \\
\text { nivel médio; garantir a efetivação do Sistema de } \\
\text { Seleção Unificada (Sisu) para os cursos superiores; } \\
\text { atuar, de forma efetiva, em parceria com outras } \\
\text { diretorias da PRE, na proposição e discussão de } \\
\text { politicas que visam garantir o acesso e a permanência } \\
\text { dos estudantes no IFSP. } \\
\end{array}$ & Alexandre Aldo Neves & Diretor & $02 / 03 / 2015$ - Atual \\
\hline
\end{tabular}

Assim como os demais IFs, o IFSP tem autonomia para criar novos cursos que atendam o desenvolvimento econômico e social da cidade em que estão inseridos no Estado de São

\footnotetext{
${ }^{9}$ http://www.ifsp.edu.br/index.php/instituicao/comite-tecnico-profissional.html
} 
Paulo. Como dito anteriormente, o Instituto reserva 50\% das vagas para cursos técnicos (subsequentes, concomitantes, integrados e Educação de Jovens e Adultos) e 20\% para licenciaturas, principalmente nas áreas de Ciências e Tecnologias - os demais cursos completam a porcentagem.

Em 2015, o IFSP atendeu na faixa de 40 mil alunos matriculados nos multicampi e campi avançados e 3.500 alunos nos polos de Educação a Distância.

Nesse cenário, a unidade do campus São Paulo dispõe de cinco cursos técnicos integrados ao ensino médio, três cursos técnicos subsequentes ou concomitantes ${ }^{10}$, cinco cursos de tecnologia, seis cursos de licenciatura, cinco cursos de graduação, quatro cursos lato sensu e quatro cursos stricto sensu, atendendo por volta de 6 mil discentes, com mais de 120 técnicos administrativos e 300 docentes.

\subsubsection{O InStituto Federal de EducaÇão, Cî̂nCia e TeCnOlOGia - bibliotecas}

As literaturas sobre bibliotecas nos centros de educação profissional, anteriores aos IFs, são escassas. São bibliografias conhecidas da época, os livros Instalação de bibliotecas em escolas técnicas industriais de José Maria de Araújo Souza de 1965, o Manual de serviços para bibliotecas de escolas técnicas industriais de Dóris de Queiroz Carvalho em 1966 e, da mesma autora, Bibliotecas de escolas técnicas industriais: manual de organização e funcionamento" de 1970 .

De fato, isso deve ser resultado das poucas Escolas Agrícolas, ETs e EFTs adotarem bibliotecas. De acordo com Santos (2017, p. 63) durante anos as bibliotecas vinculadas às escolas técnicas e profissionalizantes passaram despercebidas nas leis e decretos. As bibliotecas ganharam visibilidade apenas diante do peso do reconhecimento do equipamento, em avaliação efetuadas pelo MEC, nos cursos superiores implementados nessas instituições, por meio do

\footnotetext{
${ }^{10}$ Oferecido a quem já concluiu o ensino fundamental e tenha concluído ou esteja cursando, no mínimo, o segundo ano do ensino médio.
} 
Decreto Federal 5.773/2006 que “dispõe o exercício das funções de regulamentação, supervisão e avaliação de instituições de educação superior e cursos superiores de graduação e sequenciais, no sistema federal de ensino." A literatura sobre bibliotecas nos centros de educação profissional anteriores aos IFs é escassa. São obras conhecidas da época: o livro Instalação de bibliotecas em escolas técnicas industriais (1965), de José Maria de Araújo Souza; o Manual de serviços para bibliotecas de escolas técnicas industriais (1966), de Dóris de Queiroz Carvalho; e, da mesma autora, Bibliotecas de escolas técnicas industriais: manual de organização e funcionamento (1970).

De fato, isso deve ser resultado das poucas Escolas Agrícolas, ETs e EFTs a adotarem bibliotecas. De acordo com Santos (2017), durante anos, as bibliotecas vinculadas às escolas técnicas e profissionalizantes passaram despercebidas nas leis e decretos. Ganharam visibilidade apenas diante do peso do reconhecimento do equipamento, quando tiveram início as avaliações efetuadas pelo MEC nos cursos superiores, medida implementada por meio do Decreto Federal no 5.773/2006, que “dispõe o exercício das funções de regulamentação, supervisão e avaliação de instituições de educação superior e cursos superiores de graduação e sequenciais, no sistema federal de ensino".

Os instrumentos de avaliação para reconhecimento dos cursos colocaram as bibliotecas em evidência e passassem a exigir maior cuidado por parte dos diretores das unidades. Podemos afirmar que o número de pesquisas na área era reduzido até os primeiros anos da década de 2000, pois havia poucos bibliotecários nesses centros profissionalizantes. Hoje, o número de estudos sobre IFs está crescendo mediante alguns fatores, como: instituição recente com muitas peculiaridades; aumento de profissionais através dos constantes concursos públicos; profissionais motivados; incentivos financeiros correspondentes ao grau de pós-graduação; afastamento remunerado, desde que o servidor cumpra algumas condições. 
Além dos instrumentos de avaliação e aumento de literatura, há uma maior organização para sistematizar ações nas bibliotecas dos IFs, como, por exemplo, a Comissão Brasileira de Bibliotecas das Instituições da RFEPCT (CBBI), com representantes de todas as regiões do país (Fórum Nacional..., 2011), que tem, como objetivo:

\footnotetext{
- representar as Bibliotecas das RFEPCT junto aos diversos segmentos organizados da sociedade, tais como: órgãos governamentais; entidades ligadas à educação, pesquisa e extensão; sociedade civil; dentre outros;

- atuar como veículo de articulação, discussão, deliberação, encaminhamento, acompanhamento e execução das políticas e ações necessárias ao desenvolvimento das Bibliotecas ligadas a RFEPCT;

- desenvolver atividades de capacitação, estudos, pesquisas e propostas vinculadas às atividades das Bibliotecas da Rede. (Comissão Brasileira de Bibliotecas das Instituições da RFEPCT, 2017)
}

Becker e Faqueti (2015, p. 44) afirmam que, “embora a RFEPCT seja centenária, a história de suas bibliotecas é marcada por mudanças". As bibliotecas das Escolas Agrícolas, ETs e EFTs que existiam apresentavam atributos de bibliotecas escolares, de acordo com as características das unidades relacionadas. Posteriormente, tendo em vista a proposta dos Cefets, passaram a ser escolares - por conta do público do ensino técnico integrado ao médio - e universitárias - por comportarem discentes do ensino superior.

Santos, Boccato e Hoffmann (2013, p. 65) afirmam que "as bibliotecas do IFSP não possuem autonomia e independência, estando elas vinculadas diretamente aos seus respectivos campi, e estes, por sua vez, vinculados aos seus respectivos IFs". A integração das escolas convertidas em IFs aprofundou a natureza heteróclita das bibliotecas. Além do público escolar e de ensino superior atendido nos antigos Cefets, acrescentaram-se discentes de pós-graduação lato sensu e stricto sensu, licenciatura, EJA, cursos de curta duração, entre outros.

Como consequência, as bibliotecas dos IFs “[...] caminham na busca de sua construção indenitária, abarcando uma junção de tipologias e olhares a serem refinados e construídos” (SANTOS, HOFFMANN e BOCCATO, 2011, p. 1). As autoras sugerem que as bibliotecas dos institutos devem ser estudadas a partir da tipologia de bibliotecas escolares, especializadas e universitárias. 
Com base nos trabalhos dessas autoras, realizamos a seguinte representação:

Figura 5 - Tipologia de Bibliotecas

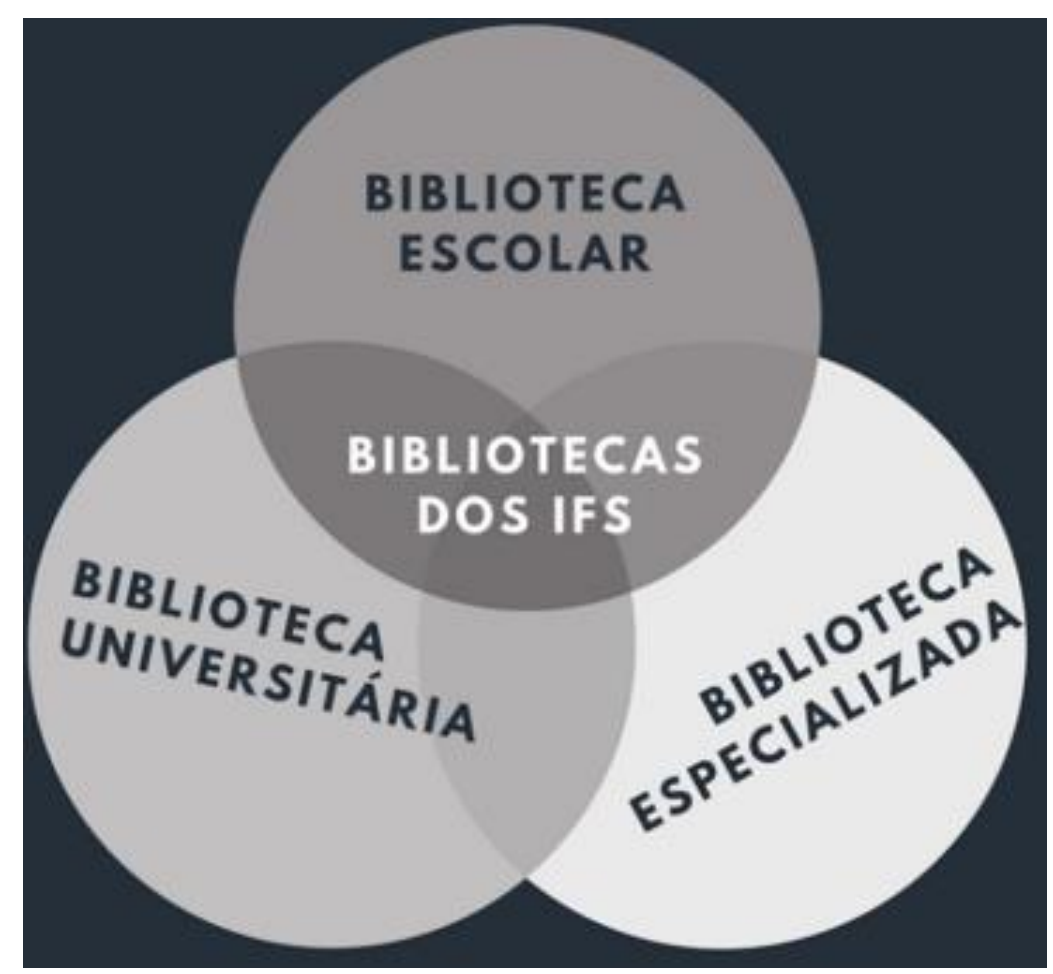

Fonte: Santos, Hoffman e Boccato

De acordo com Santos, Boccato e Hoffmann (2011, p. 130), as tipologias apontadas são

legitimadas pela seguinte constatação:

Biblioteca universitária: os Institutos Federais podem ofertar cursos superiores em tecnologia, licenciaturas e pós-graduação lato sensu e stricto sensu;

Biblioteca escolar: os Institutos Federais podem ofertar cursos técnicos integrados ao ensino médio;

Biblioteca especializada: acervo especializado em suas respectivas áreas de atuação, de acordo com a oferta de cursos.

43):

Equivalente conclusão tipológica é apontada pelas autoras Becker e Faqueti (2015, p.

observa-se que começam a iniciar os primeiros ensaios sobre os tipos de bibliotecas que a constituição da RFEPCT requer: escolares, universitárias, especializadas e tecnológicas. Importante que o leque de tipologias pode ser amplo, em virtude também de ser ampla a oferta de cursos oferecidos por esta Rede de ensino.

As autoras Camurça, Araújo e Morais (2013, p. 3), na mesma linha de raciocínio, definem que a biblioteca dos IFs é

uma biblioteca que não é exclusivamente escolar, (mas atende ao nível básico e médio), que não é unicamente especializada (embora contenha assuntos específicos), 
que não é somente superior ou universitária (mas compreende a pesquisa e extensão) e que não é pública (porém atende ao público em geral)

Os primeiros estudos de Sônia Oliveira Matos Moutinho interpretavam a tipologia das bibliotecas dos IFs como tecnológica. Entretanto, a pesquisadora afirma que "hoje, percebemos que uma melhor definição voltada para os tipos de usuários para quem essas bibliotecas prestam serviços, seria melhor denominada como bibliotecas multiníveis”, pois essas bibliotecas se tornaram escolares, universitárias e especializadas, para atender a demanda dos diferentes níveis de público que as frequentam: ensino médio, técnico, graduações e pós-graduações tecnológicas, estudantes de programas como o Programa Institucional de Bolsas de Iniciação Científica (Pibic), Plano Nacional de Formação de Professores (Parfor), Mulheres Mil, Rede Nacional de Certificação Profissional (Certific), entre outros (MOUTINHO, 2014, p. 71).

Ao encontro das tipologias apontadas, a pesquisa As bibliotecas dos Institutos Federais e seu aspecto público, de Karin Bezerra de Oliveira, registra que, "além das tipologias de biblioteca escolar, biblioteca universitária e biblioteca especializada, há também a presença da tipologia de biblioteca pública nas bibliotecas dos Institutos Federais, mesmo que de forma mais sutil" (Oliveira, 2015, p. 43).

\begin{abstract}
O aspecto público das bibliotecas dos Institutos Federais fica mais evidente nas unidades de informação que estão abertas para atenderem a comunidade externa, seja através de consulta local ou através de outras atividades que essas bibliotecas possam oferecer a esse público. E também quando essas unidades de informação estão localizadas em cidades do interior dos estados brasileiros, onde os recursos informacionais e equipamentos culturais são escassos ou quase inexistentes. Nessas situações, as bibliotecas dos Institutos Federais são a única fonte de informação para aquela localidade e por isso devem estar atentas a sua função e responsabilidade social perante essa comunidade. (Oliveira, 2015, p. 44)
\end{abstract}

Os resultados da pesquisa, respondida por bibliotecários na lista de discussão do CBBI, apontaram que $80 \%$ dos IFs realizam atendimento a comunidade externa, definida pela pesquisadora como "usuários que não fazem parte da comunidade interna (alunos, docentes, técnicos administrativos e funcionários terceirizados)". 11\% das bibliotecas dos IFs oferecem 
consultas no Sistema Eletrônico do Serviço de Informação ao Cidadão (e-SIC), $21 \%$ aplicam projetos de extensão, $9 \%$ desenvolvem outras atividades, $59 \%$ efetuam consulta local nenhuma trabalha com empréstimos domiciliares. Esse último item, talvez, deva-se ao fato de que os livros, nos IFs, são tratados como materiais permanentes pelo patrimônio institucional, seguindo a Lei Federal n 4.320, de 17 de março de 1964, Art. 2, Parágrafo 20. "Para efeito de classificação da despesa, considera-se material permanente o de duração superior a dois anos”. A determinação difere nas bibliotecas públicas, que seguem a Lei no 10.753, de 30 de outubro de 2003, a qual, em seu Art. 18, afirma: "com a finalidade de controlar os bens patrimoniais das bibliotecas públicas, o livro não é considerado material permanente”.

Maria Aparecida Brito Santos (2017), em dissertação denominada Regulamentação e concepção das bibliotecas nos Institutos Federais de Educação, Ciência e Tecnologia: em busca de sua historicidade e identidade, analisou 20 artigos e 81 trabalhos apresentados em eventos profissionais, com textos completos que discutem bibliotecas dos IFs na área de Ciência da Informação entre os anos de 2009 a 2016. Do trabalho, resulta o seguinte gráfico:

Gráfico 3 - Tipologia de Biblioteca

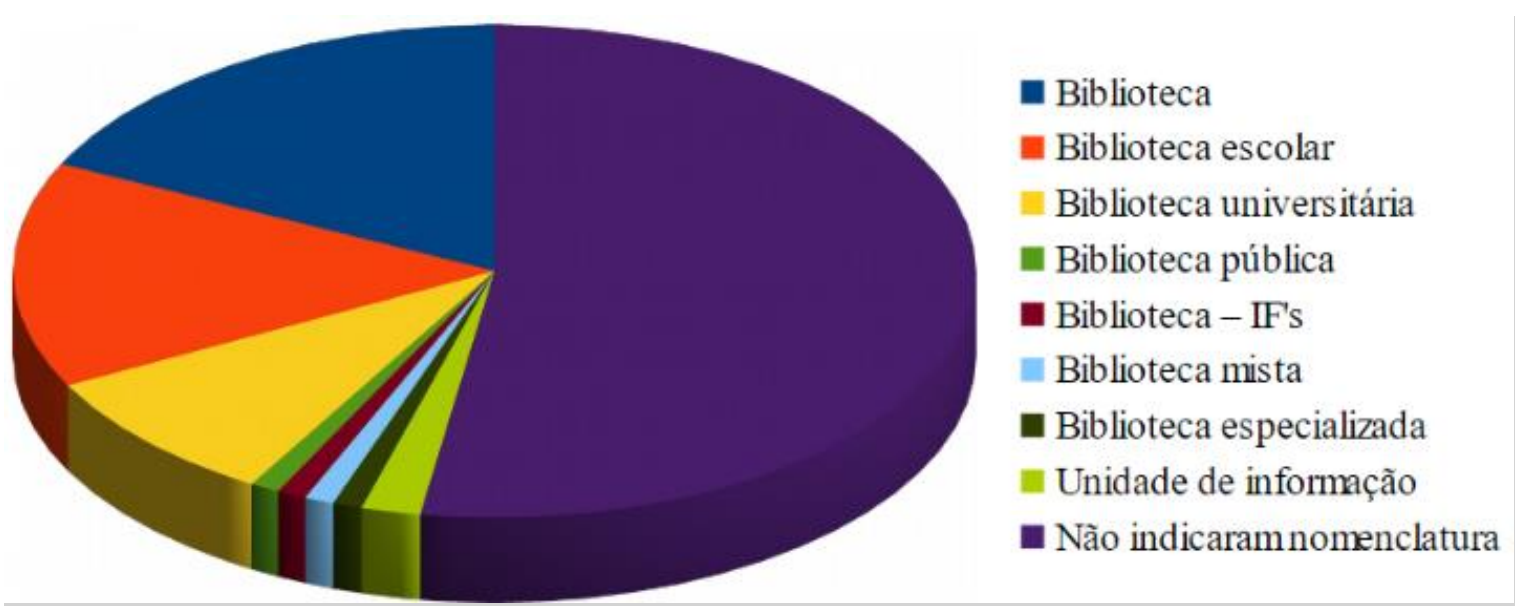

Fonte: Santos (2017, p. 83)

Levando-se em consideração esses aspectos, verifica-se que os profissionais da informação nos IFs procuram compreender 
sobre "o quê" seria a nova instituição Institutos Federais; "do quê" precisam os bibliotecários para organizar seu trabalho, planejar, avaliar, tomar decisões; "como" definir as "necessidades" informacionais, e assim proporcionar serviços de qualidade; "a quem"; e "de que maneira". (MOUTINHO; LUSTOSA, 2011, p. 4)

De acordo com Camurça, Araújo e Morais (2013, p. 10), essa "nova roupagem/identidade" de bibliotecas envolve várias disciplinas e conceitos decorrentes da Ciência da Informação, Documentação, Administração, Gestão da Qualidade e Gestão da Informação.

Para Santos, Boccato e Hoffmann (2013, p. 65), os objetivos das bibliotecas dos IFs estão centrados em "propiciar aos seus usuários infraestrutura informacional necessária para as atividades da Instituição e assim exercer atividades que oportunem o alcance da missão institucional".

Consequentemente, o objetivo maior dos bibliotecários são as construções de diretrizes comuns e meios de compartilhamento de serviços e produtos que contribuam para o desenvolvimento de todas as bibliotecas de forma equitativa, considerando que as bibliotecas possuem suas particularidades, que devem ser respeitadas (BECKER; FAQUETI, 2015, p. 73).

Nesse sentido, Moutinho e Lustosa $(2011$, p. 7) afirmam que os bibliotecários precisam “conhecer os currículos dos planos de cursos da Instituição, além dos programas de sua Rede, pesquisar os usuários para formular políticas e medidas de desempenho, controlando assim a qualidade dos serviços e produtos oferecidos", pois "cabe à biblioteca planejar suas ações de forma a atender o usuário de acordo com as demandas informacionais oriundas das disciplinas ofertadas por esta "nova' instituição"'11.

É importante mencionar que, atualmente, está em construção a sistematização dos trabalhos biblioteconômicos e das diferentes funções e tarefas dos bibliotecários. Assim, para Santos, Boccato e Hoffmann (2013, p. 73),

\footnotetext{
11 Ibidem, p. 4.
} 
o contexto sociocognitivo dos bibliotecários do IFSP é peculiar e individual, cada bibliotecário atua de forma particular e personalizada em seu ambiente de trabalho, não há a existência de políticas e diretrizes estruturais e sistêmicas para estas bibliotecas, devendo-se considerar os estágios e estruturas diferenciadas em que se encontram cada campus do IFSP.

Em virtude desses aspectos, Becker e Faqueti (2015, p. 45) esperam que, "no futuro, as bibliotecas da RFEPCT evoluam na prestação de seus serviços para interagir de forma colaborativa entre todas as bibliotecas da rede, ampliando as possibilidades com ações que favoreçam o cumprimento da missão dos Institutos Federais”.

Todas as bibliotecas das unidades de São Paulo estão vinculadas à Pró-Reitoria de Ensino (PRE), que tem seu perfil representado no quadro a seguir, com descrição, produtos e serviços, principais clientes e subunidades, de acordo com o Relatório de Gestão 2016 do IFSP $(2016)^{12}$

Quadro 5 - Descrição da Pró-Reitoria de Ensino

\begin{tabular}{|c|c|c|c|c|}
\hline \multicolumn{5}{|c|}{ PRÓ-REITORIA DE ENSINO - PRE } \\
\hline Macroprocessos & Descrição & Produtos e Serviços & Principais Clientes & Subunidades Responsáveis \\
\hline $\begin{array}{l}\text { Pró-reitoria de } \\
\text { Ensino }\end{array}$ & $\begin{array}{l}\text { - Formular e executar a } \\
\text { politica de ensino do IFSP, } \\
\text { articulada com a pesquisa e } \\
\text { extensão, em consonância com } \\
\text { as diretrizes provenientes do } \\
\text { Ministério da Educação e do } \\
\text { Conselho Superior do IFSP. }\end{array}$ & $\begin{array}{l}\text { - Analisar e emitir parecer sobre o Projeto } \\
\text { Pedagógico dos cursos da Educação Básica e } \\
\text { Profissional Técnica de Nivel Médio; Graduação e } \\
\text { de programas e projetos especiais; } \\
\text { - Supervisionar e responder pelas atividades de } \\
\text { expedição e documentação e diplomas; } \\
\text { - Coordenar a formulação de politica e a produção } \\
\text { de Educação a Distância; } \\
\text { - Acompanhar processos de regulação de cursos; }\end{array}$ & $\begin{array}{l}\text { - Público interno: alunos } \\
\text { e servidores } \\
\text { - Público externo }\end{array}$ & $\begin{array}{l}\text { - Diretorias de ensino (câmpus) } \\
\text {-Gerência educacional; } \\
\text { - Coordenadoria de Apoio ao Ensino; } \\
\text { - Coordenadoria de Registros escolares; } \\
\text {-Bibliotecas; } \\
\text { - Setor sociopedagógico. }\end{array}$ \\
\hline
\end{tabular}

A PRE é responsável pela criação e implementação das políticas de ensino. Dentro dela, está a Diretoria de Administração Acadêmica (DAA), que, até o ano de 2016, era responsável direta pela rede de bibliotecas do IFSP. A partir de 2016, as bibliotecas do IFSP obtiveram uma coordenadoria de bibliotecas junto à Reitoria, seguindo a hierarquia da DAA, subordinada hierarquicamente à PRE.

Embora existam várias discussões para a formação de um sistema integrado de bibliotecas no IFSP, os esforços ainda não se consolidaram. Por isso, nos últimos anos, dois

\footnotetext{
12 http://www2.ifsp.edu.br/acessoainformacao/relatorioGestao2016.pdf
} 
bibliotecários atuam para organizar documentos e trabalhos comuns a todas as unidades do Instituto.

Até o momento, foram publicados os seguintes documentos relacionados ao uso e organização das bibliotecas no IFSP. Alguns foram realizados em conjunto com grupos de trabalho formados por bibliotecários alocados nas unidades das bibliotecas do IFSP.

- Política de Desenvolvimento de Coleções das Bibliotecas dos IFSP, Portaria nº 967, de 09 de março de 2015,

- Regulamento de uso das bibliotecas dos IFSP, Portaria n 1.279 de 20 de abril de 2016,

- Política de Processamento Técnico dos Acervos das Bibliotecas do IFSP, Portaria ${ }^{\circ}$ 2.964, de 24 de agosto de 2015, retificada pela Portaria $n^{\circ} 2660$, de 31 de julho de 2015 ,

- Procedimentos de entrega dos trabalhos de conclusão de curso, dissertações e teses às bibliotecas do IFSP, Portaria no 264, de 24 de janeiro de 2017, Manual de Catalogação para as Bibliotecas do IFSP, Portaria n 1.246 , de 05 de abril de 2017.

- Manual de Catalogação para as Bibliotecas do IFSP, Portaria nº 1.246, de 5 de abril de 2017.

Além da publicação dos documentos coletivos, a coordenadoria de bibliotecas da Reitoria, de acordo com o Relatório de Gestão (2016), é responsável pela rede no que tange:

- ao atendimento e esclarecimento de dúvidas aos campi, estudantes e comunidade externa;

- à coordenação do funcionamento sistêmico das bibliotecas dos campi do IFSP;

- ao aprimoramento e promoção da política informacional do IFSP;

- ao apoio e acompanhamento das atividades das bibliotecas nos campi do IFSP;

- à inclusão de servidores do IFSP no sistema de gerenciamento de acesso ao Portal de Periódicos da CAPES;

- $\quad$ à inclusão de servidores das bibliotecas do IFSP no sistema Pergamum; 
- à capacitação das Coordenadorias de Bibliotecas, com foco na avaliação externa, catalogação no Pergamum e novas formas de aquisição;

- à contratação de bibliotecas virtuais e aquisição de periódicos, entre outras atividades com o objetivo de oferecer suporte às bibliotecas ligadas ao IFSP.

Sobre as bibliotecas do IFSP, as autoras Santos, Boccato e Hoffmann (2013, p. 78)

afirmaram, à época de seu estudo, que as bibliotecas se apresentavam

\begin{abstract}
em estágios iniciais de formação, constituintes de acervos em formato impressos e de pequeno porte. Além disso, estão instaladas em locais inadequados que contam com bibliotecários atuando de forma isolada nas mais variadas frentes das bibliotecas, de forma que não se faz possível explorar as habilidades e competências destes profissionais. A falta de uma visão gestora positiva acarreta consideravelmente o não crescimento e consolidação destas bibliotecas que poderiam atuar na tríade ensinopesquisa-extensão como espaços de informação postos em cena.
\end{abstract}

Considerando que o estudo foi publicado em 2013, hoje, alguns apontamentos desse registro documental estão em processo de remodelamento, mas a infraestrutura é o ponto mais delicado para toda a rede. Ainda sob o efeito recente da expansão indiscriminada, que não considerou as bibliotecas como equipamento próprio, com necessidade de construções planejadas, ou adaptadas, os espaços das bibliotecas não foram projetados, nem mesmo em institutos construídos.

Essas bibliotecas são compostas com acervos de, no máximo, 12 mil exemplares. Cada uma possui dois bibliotecários - em alguns casos, dependendo da direção da unidade, somamse a eles dois auxiliares de biblioteca e/ou dois assistentes administrativos.

\title{
2.1.2 Biblioteca Francisco Montojos - CAMPUS SÃo PAUlo
}

A Biblioteca Francisco Montojos recebeu o nome de um grande colaborador do ensino industrial no Brasil entre os anos de 1934 e 1942. Francisco Belmonte Montojos é descrito por Pedrosa e Santos (2015, p. 5) como

um engenheiro-industrialista-educador: engenheiro por titulação, industrialista pela orientação intelectual e educador em decorrência da longeva presença no Ministério 
da Educação e Saúde nos períodos de constituição e de instituição do novo ensino industrial brasileiro.

O artigo apresenta Montojos como uma personalidade com forte atuação técnica, mesmo diante de uma época de instabilidades políticas. Hoje, Montojos é lembrado por duas bibliotecas da RFEPCT: além da biblioteca do campus São Paulo do IFSP, objeto de análise deste estudo, a biblioteca do campus Teresina Central do IF do Piauí também leva o nome do engenheiro, com um pequeno acréscimo: Biblioteca Dr. Francisco Montojos.

Estruturalmente, as bibliotecas do IFSP estão vinculadas às Coordenadorias de Apoio ao Ensino (CAE) de seus campi (SANTOS; BOCCATO; Hoffmann, 2013, p. 72). Entretanto, no campus São Paulo, a Biblioteca Francisco Montojos está ligada à Diretoria Adjunta de Administração Escolar (DAE), que, hierarquicamente, conecta-se à Diretoria de Ensino (DEN). A principal missão da Biblioteca é a de oferecer suporte informacional ao tripé ensino, pesquisa e extensão. Para isso, é destinada aos alunos regularmente matriculados em todos os níveis de ensino, professores, técnicos administrativos e à comunidade externa.

Os discentes não precisam efetuar inscrição na Biblioteca para utilização dos serviços, desde que o aluno esteja regularmente matriculado; a comunidade externa utiliza os serviços in loco. Assim, são atendidos por volta de 150 usuários diariamente.

A Francisco Montojos ocupa $560 \mathrm{~m}^{2}$ e é composta por sala de processamento técnico, coordenação, espaço do acervo e salão de estudos. O salão possui 3 salas para estudo coletivo, 8 mesas para estudo em grupo (6 mesas de 6 lugares e 2 mesas de 4 lugares), 12 mesas para estudo individual, 28 baias de estudo individual e 3 computadores para acesso ao catálogo da Biblioteca. A equipe, atualmente, é composta por 9 servidores federais, sendo 5 bibliotecários, 3 auxiliares de biblioteca e 1 assistente administrativo, que atendem das $8 \mathrm{~h}$ às $20 \mathrm{~h}$ de segunda a sexta e das $8 \mathrm{~h}$ às $12 \mathrm{~h}$ aos sábados.

A maior parte do acervo da Francisco Montojos é constituída pelos Projetos Pedagógicos de Curso (PPC) elaborados pela coordenação dos cursos e aprovados no Conselho 
do Campus (Concam). A outra parte do acervo é constituída por sugestões dos profissionais de biblioteca na complementação de alguns assuntos e literaturas nacionais e internacionais.

Até o ano de 2015, o acervo era catalogado em um sistema de biblioteca simples e improvisado denominado Nambei, desenvolvido no IFSP, destinado a uma biblioteca escolar sem muita previsão de crescimento. O sistema era ligado a outros módulos administrativos, que foram substituídos por outros softwares, deixando a Biblioteca completamente dependente do único profissional de Tecnologia da Informação com conhecimento técnico para alterações do módulo Biblioteca. O sistema não realizava controle de autoridade, tinha graves limitações de pesquisa, gerava poucos relatórios (e bem superficiais), não podia ser acessado de outro ponto fora dos campi e bloqueava empréstimos em todo final e início de calendário acadêmico sem que nada pudesse ser feito para reparar esse erro.

O IFSP adquiriu, então, o sistema Pergamum. Nele, o campus São Paulo catalogou cerca de 27 mil itens de 2015 a 2017, visto que não foi possível a migração do sistema anterior, conforme os resultados do Grupo de Trabalho proposto para analisar a viabilidade de migração dos dados de catalogação. Para isso, os espaços do acervo e do salão de estudos tiveram as entradas separadas, tendo em vista a infraestrutura precária da Biblioteca Francisco Montojos.

Como um espaço não planejado, apresentava diversos problemas. Por isso a realização da reforma que começou no final de dezembro de 2017, com intenção de corrigir problemas estruturais críticos de acessibilidade, falta de espaço para acervo e de fazer uma reorganização física de atendimento ao público. O arranjo da infraestrutura está em andamento, com previsão de término no final de 2018. 


\subsection{FORMAÇÃO E DESENVOLVIMENTO DE COLEÇÕES}

No passado, os acervos eram desenvolvidos com a lógica "de se colecionar praticamente tudo o que existia disponível, uma vez que a produção editorial estava ainda em seu estágio inicial" (WEITZEL, 2002, p. 62).

A partir da Idade Moderna, com o aumento do fluxo bibliográfico, houve uma grande preocupação em racionalizar o desenvolvimento de coleções para evitar "o fato de que boa parte da produção colocada no mercado por esta 'explosão' é constituída, na realidade, de material de pouca importância, repetindo apenas o que outros haviam dito ou discutido anteriormente a eles, sem nada acrescentar de novo" (VERGUEIRO, 1993, p. 1).

Conforme aponta Figueiredo (1990, p. 9), os bibliotecários eram muito criticados por basearem as suas atividades "em suposições irreais, tais como: tudo que é oferecido é demandado e tudo que é demandado é fornecido". A aplicação do desenvolvimento de coleções evitaria a ilusória percepção de perfeito conhecimento do uso, do comportamento e das práticas da comunidade frequentadora.

Os norte-americanos foram pioneiros no progresso da área de desenvolvimento de coleções, e até hoje têm sido referência. Entretanto, Figueiredo (1990, p. 9) afirma

Embora o uso da literatura estrangeira para servir de embasamento às orientações/recomendações tenha sido feito de maneira bastante ampla, levou-se em consideração o fato de que uma biblioteca universitária ou serviço de informação especializada no país não tem que, necessariamente, ser idêntico ao de um país desenvolvido.

De acordo com Vergueiro (1993), apesar da preocupação com o desenvolvimento de coleções parecer sempre ter existido, os profissionais brasileiros demoraram para aderir à prática, em comparação aos norte-americanos. Porém, quando aderiram, houve o que o autor chama de boom nos periódicos de Biblioteconomia, que buscavam conscientizar os profissionais de que o desenvolvimento de coleções era maior do que a construção de acervos com novas aquisições.

As bibliotecas não devem mais almejar crescer de maneira indefinida, nenhuma biblioteca pode ser autossuficiente em matéria de informação, é preciso que os 
bibliotecários brasileiros assumam que o essencial não é mais a posse dos materiais e que é muito importante e relevante que o sistema proporcione a possibilidade de o usuário ter acesso ao material que necessita, onde quer que se encontre localizado. (FIGUEIREDO, 1990, p. 43).

Por isso, o planejamento é um fator essencial para Weitzel (2002, p. 180) quando este afirma que "formar e desenvolver coleções vai mais além que selecionar e adquirir obras". O desenvolvimento de coleções é realizado por meio de planejamento. Nesse contexto, Miranda (2007, p. 87) considera o planejamento "fator fundamental à plena consecução dos objetivos das bibliotecas".

As principais referências na área de Desenvolvimento de Coleção enfatizam a responsabilidade do profissional bibliotecário na formação de coleções. Exemplificamos com citação de Figueiredo (1990, p. 41): “Os bibliotecários devem assumir maiores reponsabilidades para a manutenção e desenvolvimento da coleção, racionalizando-as e adequando-as para atender às necessidades dos usuários de sua instituição".

Para tanto, "não há como formar e desenvolver coleções sem se deparar com questões próprias da natureza desse processo, tais como: o quê, o porquê, o para quê, o como e para quem colecionar” (WEITZEL, 2002, p. 63).

O desenvolvimento de coleções precisa de uma metodologia perene, em harmonia com a necessidade da comunidade.

A formação, desenvolvimento e organização do acervo devem ser encarados como um processo permanente no qual as atividades de seleção, aquisição e avaliação de materiais devem permanecer em contínua sintonia com as necessidades de informação da comunidade de usuários (MIRANDA, 2007, p. 87)

Magrill e Hickey (1984) registram as etapas de desenvolvimento de coleções e algumas ideias agregadas já mencionadas:

De uma maneira geral, o desenvolvimento de coleções irá incluir a avaliação das necessidades dos usuários, a avaliação da coleção atual, a determinação da política de seleção, a coordenação da seleção de itens, o "desbastamento" e armazenagem de partes da coleção e o planejamento para compartilhamento de recursos. Entretanto, de uma maneira ainda mais geral, o desenvolvimento de coleções não é apenas uma simples atividade ou um grupo de atividades: é um processo de planejamento e de tomada de decisão. 
As citadas etapas são produtos de alguns modelos teóricos, como o de Hendrik Edelman, que, segundo Vergueiro (1993, p. 3), propôs uma hierarquia de três níveis entre os termos desenvolvimento de coleções:

1. Desenvolvimento de coleções como função de planejamento.

2. Seleção como processo de tomada de decisões.

3. Aquisição como implementação das decisões.

O segundo modelo que apresentamos é o de Baughman (1979), que procurava um padrão de relacionamento nos seguintes componentes: grupo de demandas, uso, conhecimento e biblioteconomia. De acordo com Vergueiro (1993), o desenvolvimento de coleções, segundo Baughman, é representado da seguinte forma:

Figura 6 - Desenvolvimento de coleções. Abordagem estruturalista

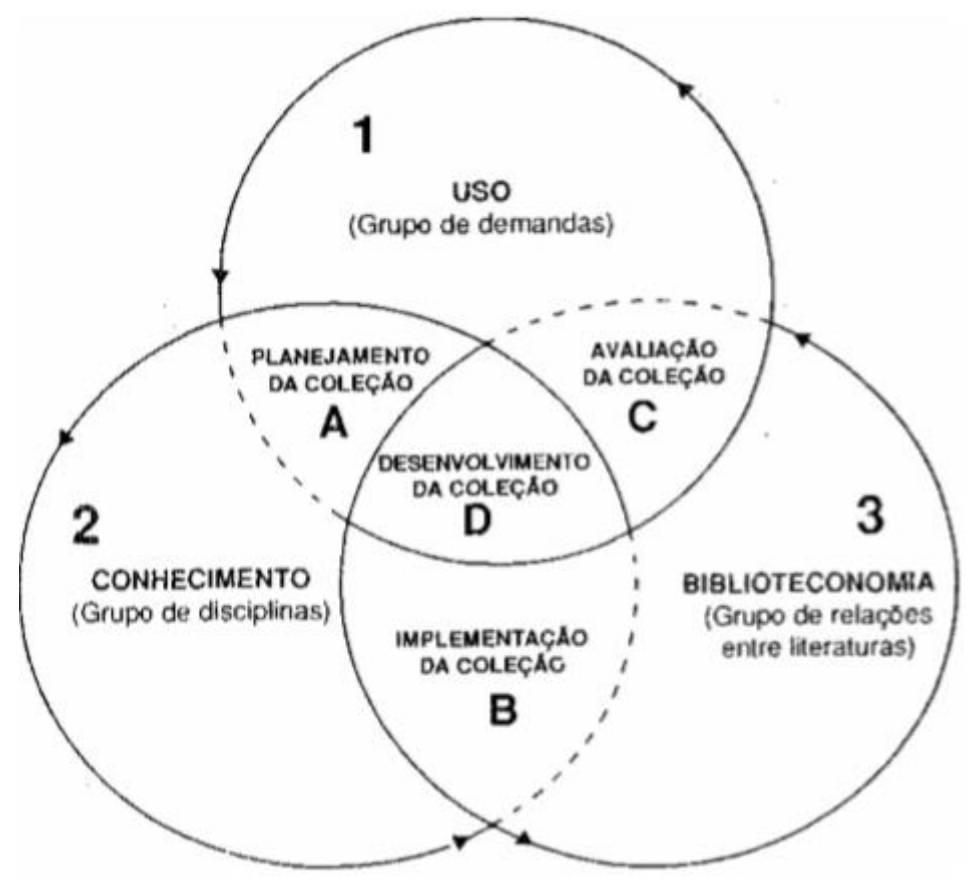

Fonte: Baughman

O exposto difere do modelo sistêmico e cíclico estabelecido por G. Edward Evans, que foca nos pontos fortes e fracos do material bibliográfico, nas etapas que não podem ser realizadas de forma isolada, nas variações de acordo com o tipo de biblioteca, nos estudos das 
necessidades da comunidade em que o equipamento está inserido e nas avaliações permanentes (VERGUEIRO, 1993).

Figura 7 - Processo de desenvolvimento de coleções

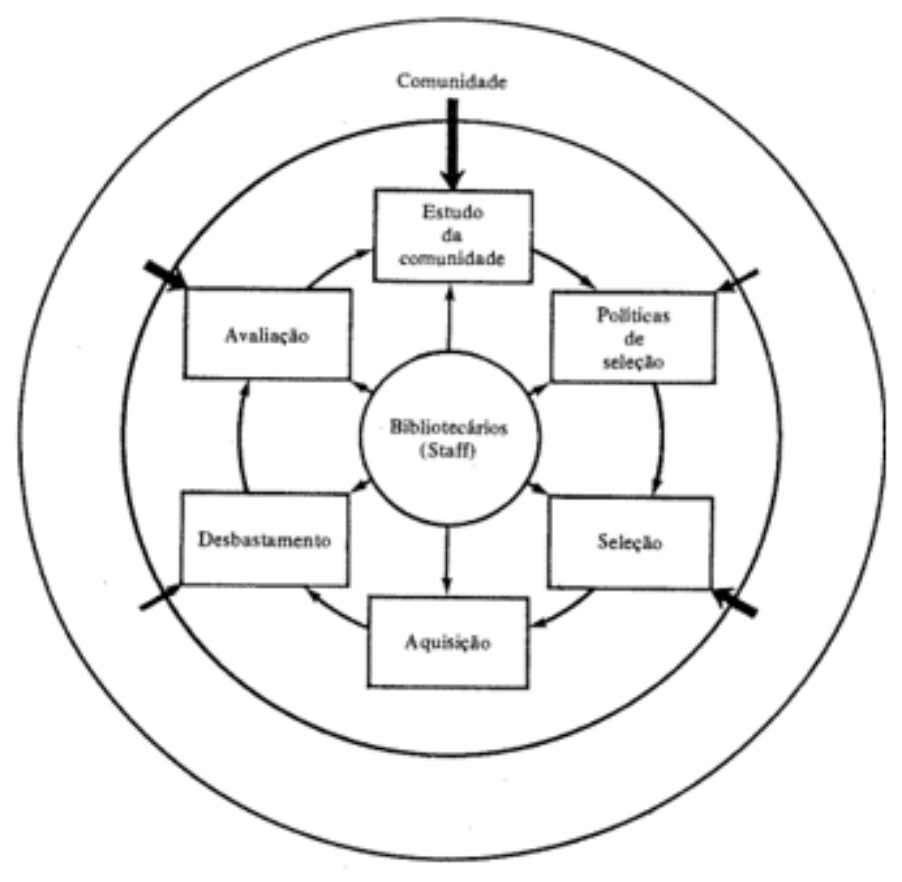

Fonte: modelo de Evans

Esse modelo exige que o bibliotecário desempenhe papel central na condução do ciclo de formação de desenvolvimento de coleções, que é composto pelas seguintes fases:

- Estudo da comunidade: para definir necessidades dos usuários.

- Política de seleção: para gerar um documento que emita decisões baseadas no resultado do estudo da comunidade, relacionando-as à missão institucional.

- Seleção: estabelecimento de critérios específicos, com as considerações gerais que influenciam a seleção: o assunto, o usuário, o documento, o preço e questões complementares com critérios que abordam o conteúdo dos documentos, a adequação ao usuário e os aspectos adicionais do documento (VERGUEIRO, 1995).

- Aquisição: atividade administrativa de implementação das decisões de seleção.

- Desbastamento: situar critérios para o desfazimento de materiais bibliográficos, 
Avaliação: averiguar se todas as fases estão sendo atingidas de forma razoável.

Embora as fases do desenvolvimento de coleções não possam ser desempenhadas de forma isolada e fora de sequência, a tipologia da biblioteca determinará a circunspecção em algumas fases.

- No modelo de Evan, o desenvolvimento de coleções admite a influência da tipologia na biblioteca da seguinte forma:

- Bibliotecas públicas: com clientela heterogênea, dinâmica, diversificada e com mudanças frequentes de interesses, o estudo da comunidade é a etapa que merece maior relevância.

- Bibliotecas escolares: por dar suporte às atividades pedagógicas das unidades escolares em que estão inseridas, a ênfase é na seleção de materiais para fins didáticopedagógicos.

- Bibliotecas universitárias: apresentam usuários homogêneos em um ambiente com objetivo de ensino, pesquisa e extensão, e têm coleções em constante crescimento para atender a pesquisa acadêmica. Por isso, a ênfase se dá na avaliação constante da coleção e no desbastamento.

- Bibliotecas especializadas: atendem as instituições a que estão subordinadas. Têm materiais específicos e, muitas vezes, não convencionais. Assim a ênfase é na etapa de aquisição.

Ainda de acordo com Vergueiro (1989, p. 29),

para cada tipo de biblioteca, a comunidade irá variar - e isso é mais que evidente. Para a biblioteca pública, comunidade são todas as pessoas que residem na jurisdição política servida por ela; para a biblioteca escolar, são todos os alunos matriculados na instituição e, também, os professores a atendê-los; para a biblioteca universitária, são os corpos docentes e discentes e, eventualmente também os funcionários; para a biblioteca especializada, é a companhia, a instituição comercial, a fundação ou empresa que a criou. De qualquer forma a comunidade não é, absolutamente [...] apenas e tão somente o usuário real. 
Todo profissional ligado à Ciência da Informação que trabalha em instituições com acervos precisa reconhecer que "quaisquer que sejam os tipos ou níveis de coleções definidas para atender as necessidades dos usuários do sistema, existe a necessidade de um instrumento sólido para permitir a consistência, uniformidade, equilíbrio e otimização dos recursos disponíveis" (FIGUEIREDO, 1990, p. 35).

No IFSP, a Política de Desenvolvimento de Coleções das Bibliotecas, publicada pela Portaria $n^{\circ}$ 967, de 9 de março de 2015, é proveniente das discussões do Grupo de Trabalho 3 (responsáveis: Etiene Siqueira Rocha e Angela Halen Claro Bembem) e tem o objetivo de estabelecer critérios para o desenvolvimento de coleções e a atualização do acervo de forma quantitativa e qualitativa, com o intuito de racionalizar e otimizar os recursos financeiros e humanos disponíveis nas bibliotecas dos campi. O documento se define como um "instrumento político-administrativo [que] visa tornar público os objetivos do acervo, bem como assegurar que as necessidades informacionais dos usuários das bibliotecas do IFSP sejam atendidas".

\subsection{ESTUDO DE USUÁRIO}

Partindo do pressuposto de que a informação é um elemento essencial para a sobrevivência do indivíduo e de que todo ser humano precisa de informação para viver em sociedade, mas nem sempre essa informação está acessível, tratada, pode ser assimilada e/ou apropriada, Moore (1999) enuncia que a sociedade da informação tem o poder de criar dois grupos: o dos indivíduos que têm acesso à informação e o dos que não têm. Por isso, alguns pesquisadores defendem que é necessário elaborar serviços de informação de acordo com as necessidades de grupos específicos, já que "a busca e o uso da informação são um processo dinâmico e socialmente desordenado que se desdobra em camadas de contingências cognitivas, emocionais e situacionais" (CHOO, 2003, p. 66). 
Para Araújo (2010, p. 25), a informação é um objeto com sentido que independe do usuário e recurso usado diante de uma situação de falta de conhecimento. Choo (2006, p. 70) afirma que:

O valor da informação reside no relacionamento que o usuário constrói entre si mesmo e determinada informação. Assim, a informação só é útil quando o usuário infundelhe significado, e a mesma informação objetiva pode receber diferentes significados subjetivos de diferentes indivíduos.

Nesse sentido, estudos de usuários são instrumentos importantes para mapear seus desejos e suas necessidades e/ou auxiliar instituições, viabilizando melhorias de produtos e serviços para o público-alvo.

Ao referir-se a estudos de usuários, a autora Figueiredo (1994, p. 7) considera que são “investigações para saber o que os indivíduos precisam em matéria de informação, ou então, para saber se as necessidades de informação por parte dos usuários de uma biblioteca, ou de um centro de informação, estão sendo satisfeitas de maneira adequada". E que a "motivação para realizar um estudo de usuários vem, geralmente, da necessidade ou desejo de se saber como está o serviço, de avaliá-lo, de obter informação de quanto uso está sendo feito, de redefinir prioridades, ou para justificar, [...] um serviço oferecido" (Figueiredo, 1990, p. 25).

Baptista (2007) aponta que os estudos de usuários realizam as investigações por meio de coleta de "dados para criar e/ou avaliar produtos e serviços informacionais, bem como entender melhor o fluxo de transferência da informação".

Para Figueiredo (1994, p. 7),

estes estudos são, assim, canais de comunicação que se abre entre a biblioteca e a comunidade a qual ela serve. São estudos necessários também para ajudar a biblioteca na previsão da demanda ou da mudança da demanda de seus produtos ou serviços, permitindo que sejam alocados os recursos necessários na época adequada.

Assim, os estudos de uso e de usuários provocam a revelação dos usuários reais e os motivos dos usuários potenciais que decidem não utilizar os serviços ofertados pela biblioteca, racionalizando os dados de como os usuários reais utilizam a informação e tentando identificar as razões dos não usuários. "Os usuários são assim encorajados a tornar as suas necessidades 
conhecidas e, ao mesmo tempo, assumir algumas responsabilidades para que essas necessidades de informação sejam atendidas pela biblioteca e centro de informação". (FIGUEIREDO, 1994, p. 7).

Segundo Lancaster (2004, p. 14), existe "o perigo de criar uma situação que se autoperpetua. Isto é, a biblioteca está constantemente melhorando sua capacidade de responder ao tipo de demanda presente, e, ao fazer isso, talvez esteja reduzindo sua capacidade de atrair para os recursos disponíveis novos usuários ou novos usos”. Por isso, é necessário evitar o risco de concentrar os serviços avaliados da biblioteca apenas nos usuários correntes e suprimir materiais ou informações que nunca se transformam em demandas.

Entretanto, antes de se realizar efetivamente um estudo de usuários, é necessário considerar que

muitas pessoas não utilizam os serviços porque, na verdade, eles precisam ser grandemente melhorados. Deve-se determinar assim se o não-usuário é devido a motivos pessoais, ao desconhecimento do serviço ou às imperfeições que podem ser remediadas. " Figueiredo, 1990, p. 24

Araújo (2016), Cunha (2007) e Figueiredo (1993) afirmam que os estudos de usuários, iniciados nos anos 1930, mudaram de enfoque ao longo das décadas e, hoje, são reconhecidos como temática de pesquisa consolidada em várias áreas, incluindo a da Ciência da Informação. Na década de 1960, os profissionais que realizavam os estudos de usuários se concentravam na análise de uso das bibliotecas. Na década de 1970, foram executados estudos sobre transferência e acesso à informação, tempo de resposta e utilidade da informação. Na década de 1980, com uso de teorias importadas do Marketing, da Psicologia e da Comunicação, entre outras perspectivas, os estudos de usuários se esmeraram na automatização para planejamento de serviços ou sistemas de informação.

Por todos esses aspectos, os especialistas em estudo de usuários perceberam que as pesquisas quantitativas não refletiam as necessidades individuais dos sujeitos em um sistema de informação. Por isso, surgiram os estudos qualitativos. De acordo com Wilson (2000), os 
estudos qualitativos têm forte influência das Ciências Sociais e são aplicados considerando a percepção do usuário, com a intenção de melhorar o prognóstico de serviços baseados em comportamento e uso da informação.

Araújo (2016, p. 63) considera que, no primeiro fórum Information Seeking in Context (ISIC), realizado em 1996, atualmente denominado The Information Behaviour Conference, os pesquisadores concluíram que existem três abordagens de estudos de usuários: o estudo de uso, abordagem pioneira, da década de 1930, com grande impacto até a década de 1970; o estudo de comportamento informacional, surgido no final da década de 1970; e o estudo de práticas informacionais, surgido nos anos 1990.

O evento concluiu que as três abordagens de estudo de usuários são práticas contínuas, mesmo que algumas ocorram de forma esporádica. Para Araújo (2006), existem poucas pesquisas no campo cognitivo da abordagem do comportamento informacional e da perspectiva construcionista e pragmática das práticas informacionais.

Os autores Araújo (2010, p. 25 apud Capurro, 2003), Hjorland (2002) e Frohmann (2008) dissertam sobre a aplicação dos três paradigmas da Ciência da Informação nos estudos de usuários:

- A abordagem tradicional de estudos de usuários baseia-se na teoria "entre a veiculação física de um sinal e a transmissão de uma mensagem”, definição de paradigma físico, na Ciência da Informação. Os estudos são direcionados sob o enfoque do Sistema de Informação e entendem os usuários como sujeitos isolados.

- A abordagem alternativa de estudos de usuários é fundamentada no paradigma cognitivo e abrange os aspectos do relacionamento entre os elementos em um determinado processo. Os estudos estão concentrados nos usuários, principalmente no comportamento deles. 
- O paradigma social ainda está em construção no campo dos estudos de usuários, mas entende-se que, nas pesquisas, os sujeitos estabelecem critérios de realidade e informação de forma coletiva.

Para essa pesquisa, consideramos o estudo de usuário como um mecanismo para melhor conhecê-lo. Entretanto, por causa da escassez de tempo, não foi possível aplicar o estudo em sua integralidade. 


\subsection{SERVIÇO DE REFERÊNCIA E INFORMAÇão (SRI)}

Para a unidade de informação prestar um serviço eficaz, é necessário compreender do que o usuário precisa. Segundo Foskett (1969, p. 15), “a natureza da informação não condiciona a natureza dos meios empregados para localizá-la, e, em ambos os casos, o consulente primeiro precisa enunciar aquilo que deseja saber e, às vezes, aquilo que já sabe". O autor defende que só assim "é possível proporcionar ao consulente tanta informação quanto seja necessária, a fim de preencher uma lacuna em seu conhecimento".

Em consequência disso, para sanar seus desejos e necessidades informacionais, esses usuários precisaram de um serviço de informação, o que Fujino $(1993,2000)$ define como "o conjunto de atividades sistemáticas cujo objetivo é possibilitar ao usuário o acesso às fontes de informação, para atender a necessidades especificas". De acordo com a mesma autora, os Serviços de Informação são aplicados em bibliotecas, centros de documentação, centros de informação, sistemas de informação, núcleos de informação, entre outros, de acordo com suas respectivas missões institucionais.

Alguns argumentam que um dos principais serviços de informação em uma unidade de informação é o serviço de referência. Conhecer as necessidades informacionais dos usuários e encaminhar o material ideal de forma individualizada é um dos requisitos principais do serviço de referência, que age como um canal de informação eficaz ao mediar o sujeito até o conhecimento.

De acordo com Jesus e Cunha (2012, p. 113), "o serviço de referência serve como um mediador entre o conhecimento disponibilizado e o usuário que fará uso desse conhecimento, pois, sem a participação do mediador, a informação recebida dificilmente seria eficiente ou de qualidade".

Em virtude dos fatos mencionados, para garantir a qualidade e eficiência da informação ofertada, o serviço de referência precisa ser realizado por profissionais bem instruídos, com o 
objetivo de dirimir as dúvidas da comunidade, que procura informações de forma privativa, conforme afirma Grogan (2001): “A finalidade do serviço de referência é reduzir as incertezas dos usuários e ministrar a assistência de maneira individualizada".

Segundo Accart (2012, p. 14), Ranganathan, considerado um dos nomes mais influentes da Biblioteconomia, define o serviço de referência como o "verdadeiro trabalho" do bibliotecário. É importante mencionar que Ranganathan exerceu a função de bibliotecário de referência por muitos anos. Por isso, sua fala ganha o peso do empirismo da experiência pessoal.

Embora as tecnologias venham evoluindo de forma vertiginosa, pode-se afirmar que o serviço de referência ainda é "uma atividade essencialmente humana” (GROGAN, 2001, p. 22). Segundo Grogan, o serviço de referência "atende a uma das necessidades mais profundamente arraigadas da espécie, que é o anseio de conhecer e compreender", premissa corroborada por Accart (2012, p. 13): “O 'serviço de referência' abrange certo número de atividades e competências com a finalidade de oferecer [...] uma resposta a uma pergunta”.

Para Macedo (2005, p. 371), o serviço de referência e informação é o coração da biblioteca, onde "recaem as funções de atendimento, orientação, divulgação, promoção e otimização do uso da biblioteca e, ainda, de atividades extensivas para a formação educativa, cultural e social dos estudantes".

Todos os trabalhos desenvolvidos na unidade de informação têm como objetivo disponibilizar múltiplos materiais bibliográficos para uso. Maciel e Mendonça (2000, p. 34) dizem que o serviço de referência "compreende todas as atividades voltadas, direta ou indiretamente, à prestação de serviços ao usuário”. Jesus e Cunha (2012, p. 113) asseguram que "tudo que é feito em todos os outros setores, como a catalogação, indexação, processos técnicos, aquisição, entre outros, volta-se para o setor de referência, pois é nele que se encontra a razão final de toda existência de uma biblioteca: o usuário". 
Figueiredo (1990, p. 46) revela que as ações mais comuns do serviço de referência são a provisão de documentos, informações e auxílio bibliográfico, o serviço de alerta, a orientação ao usuário e o auxílio editorial.

Segundo Accart (2012, p. 32), deve-se estabelecer uma política de serviço de referência, levando-se em conta a seleção na formação e no desenvolvimento de coleções, serviços e produtos de informação e a participação em rede pela unidade de informação. Essa política deve estar focada em três objetivos que o serviço de referência transmitiria:

1. Imagem institucional.

2. Cerne de excelência para o atendimento.

3. Mediador entre uma necessidade de informação e as fontes de informação.

$\mathrm{O}$ autor ${ }^{13}$ destaca que o serviço de referência deve ser projetado de modo diferente, conforme política, missões e objetivos institucionais, mas sempre com o mesmo desígnio: auxiliar e orientar o usuário na busca da informação relevante.

Da mesma maneira, a política de serviço de referência deve prever os serviços presenciais e virtuais. Hoje, a biblioteca pode oferecer diversos serviços de informação não presenciais. Por isso, de acordo com Palm e Nehmy (1998, p. 82), “o deslocamento das relações sociais de contextos locais de interação [foi reestruturado] através de extensões indefinidas de tempo-espaço".

A relação dos usuários com a biblioteca ficou mais dinâmica e participativa. Essa mudança de comportamento informacional tem influenciado os serviços oferecidos, mas não a ponto de anular ou modificar os serviços tradicionais. Por isso, "o serviço de referência virtual é tido como um prolongamento [do serviço de referência presencial], embora possa ser tratado como um serviço à parte” (ACCART, 2012, p. 163).

\footnotetext{
13 Ibidem, p. 14.
} 
É importante salientar que, de acordo com Volant (1997 apud Accart, 2012, p. 17), cada vez mais, a real necessidade não é mais por serviços e produtos de informação tradicionais, mas por serviços e produtos elaborados de modo focado, em um contexto de utilização particular e em um nível de elaboração apropriado.

Partindo-se do pressuposto de que, para Souza e Motoyama (2014, p.156), “o espaço da biblioteca não pode ser passivo, é preciso que se pense em uma organização dinâmica capaz de mediar o contato dos sujeitos com o material de leitura", deve-se perceber que "as bibliotecas são cada vez menos uma passagem obrigatória para se ter acesso à educação, elas devem desenvolver suas atividades de mediação para acesso à informação e elaborar novas ofertas de serviços, caso desejem continuar sendo úteis” (Brochard, 2012, apud Accart, 2012, p. 16).

Dentro desse contexto, Accart (2012) define que o profissional assume um papel de mediador entre uma informação - às vezes, difícil de se entender e controlar - e o usuário potencial dessa informação. É fundamental que os usuários e os profissionais colaborem entre si, troquem informações e se ajudem mutuamente.

Tendo em vista os argumentos apresentados, concluímos que o serviço de referência tem o poder de promover a apropriação da informação pelo usuário por meio da mediação de serviços de informação. Pinto e Santos (2015), autores baseados em Fujino (2000) e Smit (2009), definem a mediação como uma "atividade necessária à promoção do acesso à informação e, fundamentalmente, à apropriação [da informação]".

Entendemos que esses conceitos devem ser trabalhados na Biblioteca Francisco Montojos, que precisa oferecer serviços informacionais que facilitem o acesso e a apropriação da informação, conforme a definição de "biblioteca mediadora". 


\section{PROCEDIMENTOS METODOLÓGICOS}

O estudo de caso é "uma modalidade de pesquisa amplamente utilizada nas ciências sociais" e tem por propósito "estabelecer uma estrutura de discussão e debate entre os estudantes" (YIN, 2000, p. 20). Além do estudo de caso, a presente pesquisa utiliza os métodos descritivo e exploratório. De acordo com Hernández Sampieri, Fernández Collado e Baptista Lucio (2013 p. 199), as pesquisas podem ser definidas como descritivas, quando consideram que "o fenômeno estudado e seus componentes medem conceitos e definem variáveis"; e exploratórias, quando analisam "problemas pouco estudados, indagam a partir de uma perspectiva inovadora, ajudam a identificar conceitos promissores e preparam o terreno para novos estudos".

O fato do estudo de caso ser um "método que abrange tudo com a lógica de planejamento, incorporando abordagens específicas à coleta de dados e à análise de dados" (YIN, 2000, p. 20) vai direcionar a pesquisa a "tratar de, pelo menos, quatro problemas: quais questões estudar, quais dados são relevantes, quais dados coletar e como analisar os resultados" (YIN, 2000, p. 41).

Com o objetivo de analisar a percepção dos usuários potenciais da Biblioteca Francisco Montojos a partir do desenvolvimento de coleções institucionais e serviços relacionados, utilizou-se a análise documental e a aplicação de questionários.

A análise documental se deu por meio de avaliação comparativa entre os seguintes documentos institucionais do IFSP: Plano de Desenvolvimento Institucional (PDI) 20142018 do e Política de Desenvolvimento de Coleções.

A consulta a fontes documentais é imprescindível em qualquer estudo de caso. Considere-se, por exemplo, que num estudo referente a determinada organização, mediante a consulta a documentos, torna-se possível obter informações referentes à sua estrutura e organização [...] (GIL, 2010, p. 121) 
A aplicação de questionários foi adotada tendo em vista a vantagem de se obterem respostas mais rápidas, precisas, com mais liberdade por conta do anonimato permitido pelo instrumento, que é descrito por Lakatos (2011, p. 86) como "instrumento de coleta de dados constituído por uma série ordenada de perguntas, que devem ser respondidas por escrito e sem a presença do entrevistador".

Os resultados obtidos com a análise da percepção da comunidade do campus São Paulo quanto à coleção e aos serviços relacionados da Biblioteca Francisco Montojos subsidiam apontamentos para a estruturação de futuros serviços de informação específicos para atender as necessidades informacionais da comunidade acadêmica.

As referências utilizadas no estudo foram colhidas por meio das seguintes palavraschave: desenvolvimento de coleções, serviço de referência, serviço de referência e informação, mediação da informação, mediação em bibliotecas, bibliotecas dos Institutos Federais, bibliotecas dos Institutos Federais de São Paulo, bibliotecas dos Institutos Federais de Educação, Ciência e Tecnologia de São Paulo.

Esses termos foram pesquisados nas seguintes fontes de informação: Portal de Busca Integrada da Universidade de São Paulo (USP), Scientific Electronic Library Online (SciELO Brasil), Portal de Periódicos Capes do IFSP, WorldCat, Biblioteca Digital Brasileira de Teses e Dissertações (BDTD), Banco de Teses e Dissertações da Universidade de São Paulo, Base de Dados de Periódicos em Ciência da Informação (BRAPCI) e Dedalus (USP).

Os dados oficiais sobre as leis, portarias, os decretos e a história até a recente expansão do Instituto Federal foram coletados nos seguintes sítios: Rede Federal de Educação Profissional, Científica e Tecnológica (RFEPCT); Instituto Federal de São Paulo; IFSP campus São Paulo; Banco de Teses e Dissertações da Universidade de São Paulo; e Diário Oficial da União, além dos trabalhos de conclusão de curso e dissertações incorporados pela Biblioteca Francisco Montojos. 
As referências incorporadas no tópico das bibliotecas do IFSP foram consultadas nas seguintes fontes: Portal de Busca Integrada da USP, Portal de Periódicos Capes do IFSP, BDTD, BRAPCI e canais supraformais, definidos por Costa (2008) como canais plurais de comunicação científica utilizados por meio das tecnologias da informação e comunicação.

A análise documental do PDI 2014-2018 e da Política de Desenvolvimento de Coleções investigou o desenvolvimento de coleções executado pela Biblioteca Francisco Montojos e se é compatível com a missão apontada no PDI.

Conforme a análise documental prosseguiu, foram acrescentados documentos para contribuir com a discussão, adicionando-se informações, atestando-se algo já posto ou apontando-se resultados dos dois documentos.

No Quadro 6, são apresentados os recursos utilizados e o contexto do uso desses documentos.

Quadro 6 - Documentos acrescentados

\begin{tabular}{|l|l|}
\hline \multicolumn{1}{|c|}{ RECURSOS } & \multicolumn{1}{c|}{ USOS } \\
\hline $\begin{array}{l}\text { Lei }{ }^{\text {o }} \text { 11.892, que institui a RFEPCT e os } \\
\text { IFs }\end{array}$ & Finalidades e objetivos do IFs \\
\hline Relatório de Gestão (2016) & $\begin{array}{l}\text { Finalidades, objetivos do IFs e dados dos } \\
\text { cursos e campus implantados }\end{array}$ \\
\hline $\begin{array}{l}\text { Sistema Unificado de Administração } \\
\text { Pública (SUAP) }\end{array}$ & Quantitativo de alunos matriculados \\
\hline Projeto Pedagógico de Curso (PPC) & $\begin{array}{l}\text { Referências bibliográficas e quantitativos } \\
\text { para a aplicação do desenvolvimento de } \\
\text { coleções }\end{array}$ \\
\hline $\begin{array}{l}\text { Lei 4.320, sobre Normas Gerais de Direito } \\
\text { Financeiro }\end{array}$ & $\begin{array}{l}\text { Materiais bibliográficos como patrimônio } \\
\text { institucional }\end{array}$ \\
\hline
\end{tabular}

Fonte: Elaborado pela autora

O conjunto de recursos subsidiou as discussões do estudo documental referentes às políticas e práticas aplicadas na Biblioteca. 
O questionário foi composto em novembro de 2017 para ser respondido em papel. Entretanto, nos dois primeiros meses de 2018, algumas questões foram modificadas e, tendo em vista o alcance dos usuários potenciais, o questionário foi convertido para formulário eletrônico por meio da ferramenta online Formulários Google.

Inserido no apêndice deste trabalho, o questionário foi composto por 21 questões - 15 questões fechadas, 5 semiabertas e 1 (uma) aberta. Das perguntas semiabertas, duas eram de múltipla escolha e todas tinham como intuito reunir dados indicados de forma voluntária pelo público participante da pesquisa, ou seja, nenhuma das questões exigia resposta obrigatória, permitindo-se ao respondente pular questões ou abandonar o questionário a qualquer momento. O público-alvo, formado por todos os sujeitos ligados ao campus São Paulo, foi informado sobre o questionário pelas mídias digitais, em e-mails de grupos e diferentes redes sociais, entre abril e maio de 2018. 


\title{
3 RESULTADOS
}

Neste capítulo, são apontados os resultados obtidos após a análise dos documentos e dos questionários.

\subsection{ANÁLISE DOCUMENTAL}

O IFSP, atualmente, é composto por 32 campi, 5 campi avançados, 1 Centro de Referência e 26 polos de Educação a Distância (Rede e-TEC Brasil), de acordo com o Relatório de Gestão 2016 do IFSP (IFSP, 2016). Número expressivo, que se consolidou sob efeito da expansão entre os anos de 2000 a 2015 e arrefeceu a partir de então.

É importante acrescentar que o planejamento de expansão não findou na gestão Dilma Rousseff. O governo de Michel Temer incluiu, em 2017, uma unidade em São José do Rio Preto $^{14}$ que não foi cogitada no PDI.

Para a execução da expansão, o Relatório de Gestão 2016 do IFSP (2016, p. 77) declara o corte de verba de $46 \%$ em relação ao ano de 2015.

\begin{abstract}
Em referência à ação orçamentária 20RG.26439 - Expansão e Reestruturação da Rede Federal de Educação Profissional e Tecnológica - IFSP, no Estado de São Paulo, a dotação inicial foi composta de $\mathrm{R} \$ 3.658 .537,00$, de recursos do MEC, um montante de emendas parlamentares estimados em $\mathrm{R} \$ 10.921 .671,00$ (emendas impositivas: $\mathrm{n}^{\circ} 15810005$ no valor de $\mathrm{R} \$ 200.000,00, \mathrm{n}^{\circ} 31340009$ no valor de $\mathrm{R} \$ 1.000 .000,00$, $\mathrm{n}^{\circ} 31820005$ no valor de $\mathrm{R} \$ 500.000,00$, e emenda de bancada $\mathrm{n}^{\circ} 71250007$ no valor de $\mathrm{R} \$ 9.221 .671,00)$ e recursos de fontes próprias da fonte 250 no valor de $\mathrm{R} \$$ $1.866 .144,00$ e da fonte 280 no valor de $\mathrm{R} \$ 192.143,00$,) totalizando $\mathrm{R} \$$ 16.638.495,00 de créditos aprovados no orçamento 2016. Comparando com a dotação inicial do exercício anterior, o valor autorizado para o exercício de 2016 da ação 20RG foi cerca de $46 \%$ menor que o de 2015.
\end{abstract}

As restrições orçamentárias serão ampliadas a partir de 2018 no MEC devido à alteração da Constituição, que permitirá o congelamento de investimento do governo federal por até vinte anos. Os 32 campi e demais unidades têm tentado se adaptar a essa nova realidade.

O campus São Paulo engloba a maior quantidade de cursos e alunos, por ser o mais antigo. Para melhor ilustrar e justificar a necessidade de estudos concentrados em uma

\footnotetext{
${ }^{14} \mathrm{http}: / /$ www.riopreto.sp.gov.br/blog/index.php/2a-audiencia-publica-para-debater-o-instituto-federal-seraamanha/
} 
comunidade tão matizada, realizamos um quadro comparativo entre a quantidade de cursos do campus São Paulo e dos três outros campi mais antigos do IFSP: Cubatão, que teve autorização de funcionamento em abril de 1987; Sertãozinho, em janeiro de 1996; e Guarulhos, em fevereiro de 2016. 
Quadro 7 - Cursos entre as unidades mais antigas do IFSP

\begin{tabular}{|c|c|c|c|c|}
\hline & CAMPUS SÃO PAULO & CAMPUS CUBATÃO & CAMPUS SERTÃOZINHO & CAMPUS GUARULHOS \\
\hline & $\begin{array}{l}\text { Autorização de Funcionamento: } \\
\qquad 27 / 02 / 1910\end{array}$ & $\begin{array}{l}\text { Autorização de Funcionamento: } \\
\qquad 01 / 04 / 1987\end{array}$ & $\begin{array}{c}\text { Autorização de Funcionamento: } \\
\text { Jan. de } 1996\end{array}$ & $\begin{array}{l}\text { Autorização de Funcionamento: } \\
\qquad 13 / 02 / 2006\end{array}$ \\
\hline Técnicos & $\begin{array}{l}\text { Técnicos Integrados ao } \\
\text { Ensino Médio: } \\
\text { 1. Eletrônica } \\
\text { 2. Eletrotécnica } \\
\text { 3. Informática } \\
\text { 4. Mecânica } \\
\text { 5. Qualidade } \\
\text { Cursos Técnicos } \\
\text { Concomitantes/Subsequentes: } \\
\text { 6. Edificações } \\
\text { 7. Eletrotécnica } \\
\text { 8. Telecomunicações }\end{array}$ & $\begin{array}{l}\text { Técnicos Integrados ao } \\
\text { Ensino Médio: } \\
\text { 1. Informática } \\
\text { 2. Educação de Jovens e } \\
\text { Adultos (EJA) } \\
\text { 3. Organização de Eventos } \\
\text { Cursos Técnicos } \\
\text { Concomitantes/Subsequen } \\
\text { tes: } \\
\text { 4. Automação Industrial }\end{array}$ & $\begin{array}{l}\text { Técnicos Integrados ao } \\
\text { Ensino Médio: } \\
\text { 1. Automação industrial } \\
\text { 2. Química } \\
\text { 3. Mecânica (Modalidade } \\
\text { EJA - Ensino de Jovens e } \\
\text { Adultos) } \\
\text { Cursos Técnicos } \\
\text { Concomitantes/Subsequentes: } \\
\text { 4. Técnico em Administração } \\
\text { 5. Técnico em Eletrônica }\end{array}$ & $\begin{array}{l}\text { Cursos Técnicos } \\
\text { Concomitantes/Subsequentes: } \\
\text { 3. Informática para Internet } \\
\text { 4. Automação industrial }\end{array}$ \\
\hline $\begin{array}{l}\text { Cursos } \\
\text { Superiores }\end{array}$ & $\begin{array}{l}\text { 9. Tecnologia em Análise e } \\
\text { Desenvolvimento de } \\
\text { Sistemas } \\
\text { 10. Tecnologia em Automação } \\
\frac{\text { Industrial }}{\text { Tecnologia em Gestão da }} \\
\text { 12. } \\
\text { 12. } \frac{\text { Tedução Industrial }}{\text { Tecnologia em Gestão de }} \\
\text { 13. } \\
\text { Turismo } \\
\text { Eecnologia em Sistemas }\end{array}$ & $\begin{array}{l}\text { 5. Tecnologia em Análise e } \\
\text { Desenvolvimento de } \\
\text { Sistemas } \\
\text { 6. Tecnologia em } \\
\text { Automação Industrial } \\
\text { 7. Tecnologia em Gestão } \\
\text { de Turismo } \\
\text { 8. Licenciatura em Letras - } \\
\text { Português }\end{array}$ & $\begin{array}{l}\text { 6. Tecnologia em Automação } \\
\text { industrial } \\
\text { 7. Tecnologia em Gestão de } \\
\text { Recursos Humanos } \\
\text { 8. Engenharia Mecânica } \\
\text { 9. Engenharia Elétrica } \\
\text { 10. Licenciatura em Química } \\
\text { 11. Licenciatura em Letras } \\
\text { 12. Programa Especial de } \\
\text { Formação de Docentes } \\
\text { para a Educação Básica }\end{array}$ & $\begin{array}{l}\text { 5. Licenciatura em } \\
\text { Matemática } \\
\text { 6. Tecnologia em Análise e } \\
\text { Desenvolvimento de } \\
\text { Sistemas } \\
\text { 7. Tecnologia em Automação } \\
\text { Industrial } \\
\text { 8. Bacharel em Engenharia de } \\
\text { Controle e Automação }\end{array}$ \\
\hline
\end{tabular}




\begin{tabular}{|c|c|c|c|}
\hline & $\begin{array}{l}\text { 14. } \frac{\text { Licenciatura em Ciências }}{\text { Biológicas }} \\
\text { 15. Licenciatura em Física } \\
\text { 16. Licenciatura em Geografia } \\
\text { 17. } \frac{\text { Licenciatura em Letras }}{18 . \text { Licenciatura em }} \\
\text { Matemática } \\
\text { 19. Licenciatura em Química } \\
\text { 21. Arquitetura e Urbanismo } \\
\text { 22. Engenharia Civil } \\
\text { Engenharia de Controle e } \\
\text { 23. Entomacão } \\
\text { 24. Engenharia de Produção }\end{array}$ & $\begin{array}{l}\text { 9. Licenciatura em } \\
\text { Matemática } \\
\text { 10. Engenharia de Controle } \\
\text { e Automação }\end{array}$ & \\
\hline Lato Sensu & $\begin{array}{l}\text { 25. Especialização em } \\
\text { Formação de Professores - } \\
\text { Enffase Ensino Superior } \\
\text { 26. Especialização em } \\
\text { Educação Profissional } \\
\text { Integrada à Educação } \\
\text { Básica na Modalidade EJA } \\
\text { - Proeja } \\
\text { 27. Especialização em } \\
\text { Aeroportos - Projeto e } \\
\text { construção } \\
\text { 28. Especialização em Gestão } \\
\text { da Tecnologia da } \\
\text { Informacão }\end{array}$ & - & $\begin{array}{l}\text { 9. Gestão de sistemas de } \\
\text { informação }\end{array}$ \\
\hline
\end{tabular}




\begin{tabular}{|c|c|c|}
\hline $\begin{array}{c}\text { Stricto } \\
\text { Sensu }\end{array}$ & $\begin{array}{l}\text { 29. Mestrado Profissional em } \\
\text { Automação e Controle de } \\
\text { Processos } \\
\text { 30. Mestrado Profissional em } \\
\text { Ensino de Ciências e } \\
\text { Matemática } \\
\text { 31. Mestrado Profissional em } \\
\text { Matemática em Rede } \\
\text { Nacional (PROFMAT) } \\
\text { 32. Mestrado Acadêmico em } \\
\text { Engenharia Mecânica }\end{array}$ & $\begin{array}{l}\text { 13. Mestrado Profissional em } \\
\text { Educação Profissional e } \\
\text { Tecnológica }\end{array}$ \\
\hline
\end{tabular}

Fonte: Elaborado pela autora 
Estatisticamente, a tipologia de cursos no campus São Paulo apresenta a seguinte porcentagem:

Gráfico 4 - Tipologia de cursos

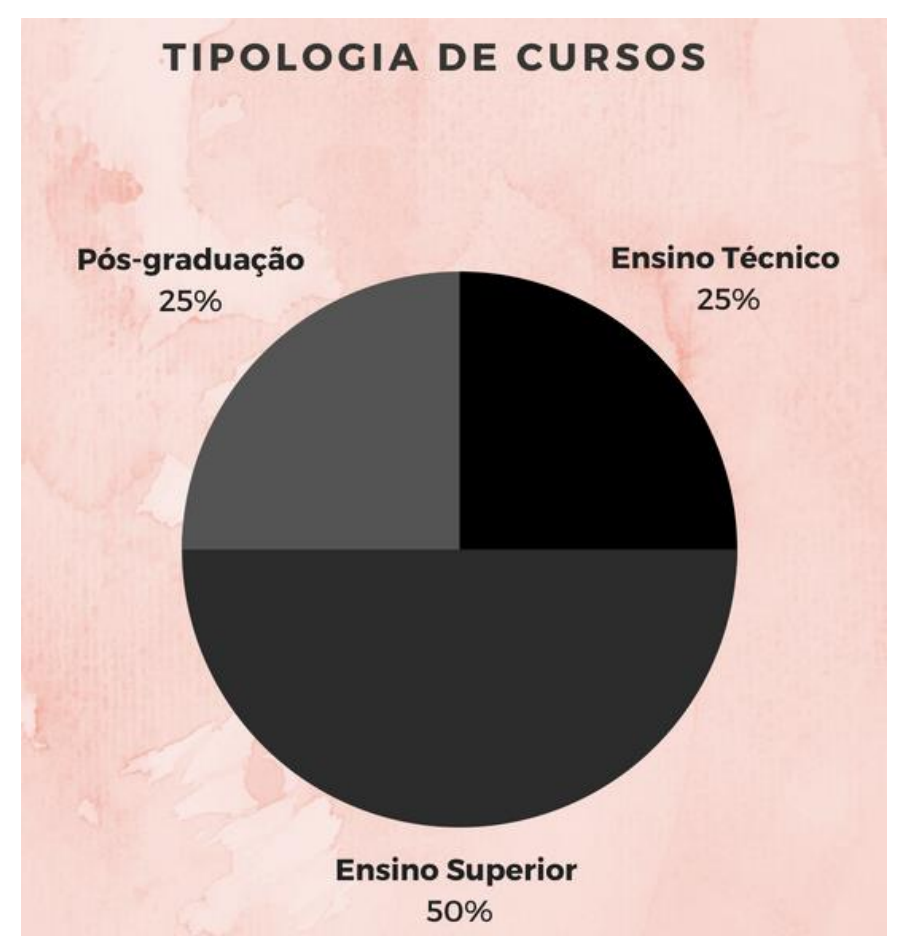

Fonte: Elaborado pela autora

Os cursos de ensino superior têm o dobro do número dos demais campis. Como unidade do IFSP, o campus São Paulo também contabiliza cursos que devem cumprir a Lei 11.892, que determina o oferecimento de $50 \%$ das vagas da instituição ao ensino técnico e $20 \%$ a licenciaturas.

Desdobrando as tipologias, verificamos os números abaixo. 
Gráfico 5 - Modalidades desdobradas

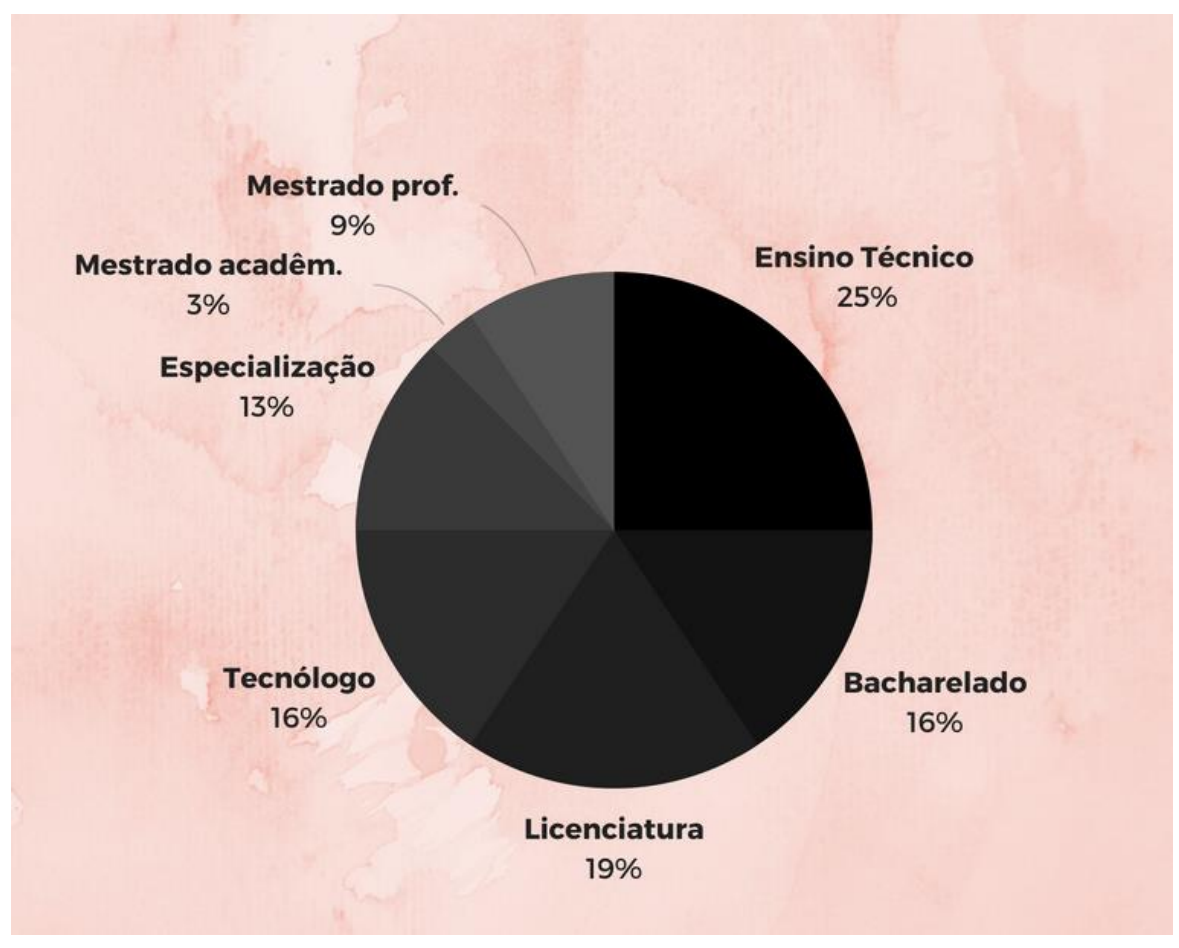

Fonte: elaborado pela autora

Os dados mostram que o campus São Paulo saltou de 3.617 alunos no primeiro ano de funcionamento, em 2008, para 13.805 discentes em 2017, compreendendo alunos dos cursos presenciais e a distância dos vários polos espalhados. Esse aumento representa o aumento na oferta de cursos ao longo dos anos.

Por outro lado, os cursos superiores da instituição formaram apenas 2.939 alunos no período de 2001-2015, o que demonstra alto número de evasão.

Tabela 1 - Número de matrículas dos cursos presenciais em todos os segmentos

\begin{tabular}{|l|l|}
\hline Ano & Número de matrículas \\
\hline 2018 & 1.918 \\
\hline 2017 & 1.637 \\
\hline 2016 & 1.458 \\
\hline 2015 & 1.266 \\
\hline
\end{tabular}


Os dados apresentados foram gerados pelo Sistema Unificado de Administração Pública (Suap), que busca integrar todas as informações administrativas do IFSP.

O PDI 2014-2018 tinha ambição maior. Abaixo, apresentamos os cursos previstos pelo Plano.

Quadro 8 - Programação de abertura de cursos técnicos (integrado, concomitante e EJA)

\begin{tabular}{|c|c|c|c|c|c|c|c|}
\hline \multirow[b]{2}{*}{ Nome de curse } & \multirow[b]{2}{*}{ Mabilitaçao } & \multirow[b]{2}{*}{ Modalidade } & \multicolumn{2}{|c|}{ Quantidade de } & \multirow{2}{*}{$\begin{array}{l}\text { Turno(s) de } \\
\text { funcions:- } \\
\text { mento }\end{array}$} & \multirow{2}{*}{$\begin{array}{c}\text { Local de } \\
\text { funcionamento }\end{array}$} & \multirow{2}{*}{$\begin{array}{l}\text { Ano previsto } \\
\text { para solieitacas. }\end{array}$} \\
\hline & & & $\begin{array}{c}\text { alunos/ } \\
\text { turma }\end{array}$ & turmas & & & \\
\hline $\begin{array}{c}\text { Técnico subsequente } \\
\text { em Traduçà e } \\
\text { Interpretaçăo de Libras }\end{array}$ & $\begin{array}{c}\text { Traduçâo e } \\
\text { interpretaçâo em } \\
\text { LIBRAS }\end{array}$ & Concomitante & 40 & 1 & Noturno & CCL-SPO & 2015 \\
\hline $\begin{array}{c}\text { Técnico em Automaçăo } \\
\text { Industrial }\end{array}$ & Téenico & Concomitante & 40 & 2 & Noturno & CAI-SPO & 2016 \\
\hline Telecomunicaçōes & Técnico & Integrado & 40 & 1 & Integral & CEO-SPO & 2016 \\
\hline $\begin{array}{c}\text { Técnico em Automaçăo } \\
\text { Industrial }\end{array}$ & Técnico & Integrado & 40 & 1 & Integral & CAI-SPO & 2017 \\
\hline $\begin{array}{c}\text { Agenciamento de } \\
\text { Viagem }\end{array}$ & Técnico & Subsequente & 40 & 1 & Matutino & CTH-SPO & 2018 \\
\hline
\end{tabular}


Quadro 9 - Programação de abertura de cursos de graduação (bacharelados, licenciaturas e tecnólogos)

\begin{tabular}{|c|c|c|c|c|c|c|c|}
\hline \multirow[b]{2}{*}{ Nome do curso } & \multirow[b]{2}{*}{ Mabilitaçăo } & \multirow[b]{2}{*}{ Modalidade } & \multicolumn{2}{|c|}{ Quantidade de } & \multirow{2}{*}{$\begin{array}{l}\text { Turno(s) de } \\
\text { funcions- } \\
\text { mento }\end{array}$} & \multirow{2}{*}{$\begin{array}{c}\text { Local de } \\
\text { funcionamento }\end{array}$} & \multirow{2}{*}{$\begin{array}{l}\text { Ano previsto } \\
\text { para solieitaça }\end{array}$} \\
\hline & & & $\begin{array}{l}\text { alunos/ } \\
\text { turma }\end{array}$ & turmas & & & \\
\hline $\begin{array}{l}\text { Superior de Tecnologia } \\
\text { da Informaçăo }\end{array}$ & $\begin{array}{l}\text { Tecnologia da } \\
\text { Informaçầo }\end{array}$ & Tecnologo & 40 & 1 & & CCl-SPO & 2014 \\
\hline $\begin{array}{c}\text { Superior de Tecnologia } \\
\text { em Eletrica - }\end{array}$ & $\begin{array}{l}\text { Elétrica - Tele- } \\
\text { comunicaçठes }\end{array}$ & Tecnollogo & 40 & 2 & Noturno & CEO-SPO & 2016 \\
\hline \multicolumn{8}{|l|}{ Telecomuniceçes } \\
\hline $\begin{array}{l}\text { Licenciature cm Letras- } \\
\text { Inglês para Graduados } \\
\text { (segunda Licenciatura } \\
\text { - complementaçăo) }\end{array}$ & $\begin{array}{l}\text { Licenciatura em } \\
\text { Inglês }\end{array}$ & Licenciałura & 40 & 1 & Vespertino & CCL-SPO & 2015 \\
\hline $\begin{array}{l}\text { Licenciatura em } \\
\text { Pedagogia }\end{array}$ & $\begin{array}{l}\text { Licenciatura em } \\
\text { Pedagogia }\end{array}$ & Licenciałura & 30 & 1 & Notumo & CCL-SPO & 2010 \\
\hline $\begin{array}{l}\text { Licenciatura em } \\
\text { Computaçåo }\end{array}$ & Lisenciatura & Lisenciatura & 30 & 1 & & CCISPO & 2014 \\
\hline $\begin{array}{l}\text { Arquitetura e } \\
\text { Urtanismo }\end{array}$ & Arquiteto & Bacharelado & 40 & 1 & Integral & CCC-SPO & 2014 \\
\hline Administraçâo & Administrador & Bacharelado & 40 & 1 & Notumo & CTH-SPO & 2015 \\
\hline $\begin{array}{l}\text { Engenharia de } \\
\text { Software }\end{array}$ & Engenheiro & Bacharelado & 40 & 2 & & $\mathrm{CCl}$ SPO & 2015 \\
\hline Enģenharia & Mecânca & Mecânica & 40 & 2 & $\begin{array}{l}\text { Diumol } \\
\text { Notumno }\end{array}$ & CME-SPO & 2014 \\
\hline Engenharia & Elétrica & Elatrotb́cnica & 26 & 2 & $\begin{array}{l}\text { Diumol } \\
\text { Notumo }\end{array}$ & CEO-SPO & 2015 \\
\hline Ençenharia & Elétrica & $\begin{array}{l}\text { Controle : } \\
\text { Automaçäo }\end{array}$ & 25 & 2 & $\begin{array}{l}\text { Diumol } \\
\text { Notumo }\end{array}$ & CALSPO & 2015 \\
\hline Ençenharia & Elétrica & Eletronica & 25 & 2 & $\begin{array}{l}\text { Diurno/ } \\
\text { Notumo }\end{array}$ & CEL-SPO & 2015 \\
\hline Enģenharia & Elétrica & $\begin{array}{c}\text { Tele- } \\
\text { comunicaçbes }\end{array}$ & 25 & 2 & $\begin{array}{l}\text { Diumo/ } \\
\text { Notumo }\end{array}$ & CEO-SPO & 2015 \\
\hline
\end{tabular}

Quadro 10 - Programação de abertura de cursos de EJA - FIC

\begin{tabular}{|c|c|c|c|c|c|c|c|}
\hline \multirow[b]{2}{*}{ Nome do curso } & \multirow[b]{2}{*}{ Habilitaçăo } & \multirow[b]{2}{*}{ Modalidade } & \multicolumn{2}{|c|}{ Quantidade de } & \multirow{2}{*}{$\begin{array}{l}\text { Turno(s) de } \\
\text { funciona- } \\
\text { mento }\end{array}$} & \multirow{2}{*}{$\begin{array}{l}\text { Local de } \\
\text { funcionamento }\end{array}$} & \multirow{2}{*}{$\begin{array}{l}\text { Ano previsto } \\
\text { para solicitaçăo }\end{array}$} \\
\hline & & & $\begin{array}{c}\text { alunos/ } \\
\text { turma }\end{array}$ & turmas & & & \\
\hline Soldagem & Mecânica & Soldador & 20 & 2 & $\begin{array}{l}\text { Diurno/ } \\
\text { Noturno }\end{array}$ & CME-SPO & 2015 \\
\hline Programador CNC & Mecânica & $\begin{array}{c}\text { Programador } \\
\text { CNC }\end{array}$ & 20 & 1 & $\begin{array}{l}\text { Diurno/ } \\
\text { Noturno }\end{array}$ & CME-SPO & 2015 \\
\hline Operador CNC & Mecânica & Operador CNC & 20 & 1 & $\begin{array}{l}\text { Diurno/ } \\
\text { Noturno }\end{array}$ & CME-SPO & 2015 \\
\hline Eletricista & Elétrica & Instalador & 20 & 3 & $\begin{array}{l}\text { Diurno/ } \\
\text { Noturno }\end{array}$ & CEL-SPO & 2015 \\
\hline
\end{tabular}


Quadro 11 - Programação de abertura de cursos de pós-graduação

\begin{tabular}{|c|c|c|c|c|c|c|}
\hline \multirow[b]{2}{*}{ Nome do curso } & \multirow[b]{2}{*}{ Modalidade } & \multicolumn{2}{|c|}{ Quantidade de } & \multirow{2}{*}{$\begin{array}{c}\text { Turno(s) de } \\
\text { funciona- } \\
\text { mento }\end{array}$} & \multirow{2}{*}{$\begin{array}{l}\text { Local de } \\
\text { funcionamento }\end{array}$} & \multirow{2}{*}{$\begin{array}{l}\text { Ano previsto } \\
\text { para solicitaçăo }\end{array}$} \\
\hline & & \begin{tabular}{|l|} 
alunos/ \\
turma
\end{tabular} & turmas & & & \\
\hline $\begin{array}{l}\text { Especialização em Gestão de } \\
\text { Tecnologia da Informaçăo }\end{array}$ & Lato Sensu & 30 & 1 & & $\mathrm{CCl}-\mathrm{SPO}$ & 2014 \\
\hline $\begin{array}{l}\text { Especializaçăo em Formaçăo de } \\
\text { professores para educaçăo inclusiva }\end{array}$ & Lato sensu & 40 & 1 & Noturno & CCL-SPO & 2015 \\
\hline $\begin{array}{c}\text { Especialização em Gestão } \\
\text { Estratégica de Turismo }\end{array}$ & Lato Sensu & 40 & 1 & $\begin{array}{l}\text { Noturno / } \\
\text { Sábado }\end{array}$ & CTH-SPO & 2015 \\
\hline Especializaçăo em Energia & Lato Sensu & 20 & 1 & Noturno & CEL-SPO & 2016 \\
\hline $\begin{array}{l}\text { Especialização em Tradução e } \\
\text { Interpretaçăo da LIBRAS }\end{array}$ & Lato sensu & 30 & 1 & $\begin{array}{l}\text { Diurno } \\
\text { (sábados) }\end{array}$ & CCL-SPO & 2016 \\
\hline Especializaçăo em Letras & Lato sensu & 40 & 1 & Noturno & CCL-SPO & 2017 \\
\hline $\begin{array}{l}\text { Mestrado Profissional em Ensino de } \\
\text { Ciências e Matemática }\end{array}$ & $\begin{array}{l}\text { Mestrado } \\
\text { Profissional }\end{array}$ & 15 & 1 & Diurno & CCT-SPO & 2014 \\
\hline $\begin{array}{c}\text { Mestrado Profissional em Engenharia } \\
\text { Civil }\end{array}$ & $\begin{array}{l}\text { Mestrado } \\
\text { Profissional }\end{array}$ & 25 & 1 & Integral & CCC-SPO & 2015 \\
\hline $\begin{array}{c}\text { Mestrado Profissional em Educação } \\
\text { de Jovens e Adultos }\end{array}$ & $\begin{array}{l}\text { Mestrado } \\
\text { Acadêmico }\end{array}$ & 20 & 1 & Sábado & CSC-SPO & 2016 \\
\hline Mestrado em Energia & Stricto Sensu & 20 & 1 & Noturno & CEL-SPO & 2017 \\
\hline $\begin{array}{l}\text { Doutorado em Materiais e processos } \\
\text { de fabricaçăo mecânica }\end{array}$ & Stricto Sensu & 20 & 1 & Noturno & CME-SPO & 2016 \\
\hline Doutorado em Controle e Automaçăo & Stricto Sensu & 20 & 1 & Noturno & CAI-SPO & 2016 \\
\hline Doutorado em Engenharia Civil & Stricto Sensu & 25 & 1 & Integral & CCC-SPO & 2017 \\
\hline
\end{tabular}

Quadro 12 - Programação de abertura de cursos a distância

\begin{tabular}{|c|c|c|c|c|c|}
\hline Nome do curso & Habilitaçăı & Modalidade & $\begin{array}{c}\text { Abrangeneia } \\
\text { geográfica }\end{array}$ & $\begin{array}{c}\text { Polos de apoio } \\
\text { presencial }\end{array}$ & $\begin{array}{c}\text { Ano previsto } \\
\text { para solicitaçăo }\end{array}$ \\
\hline $\begin{array}{c}\text { Especializaçăo em Planejamento } \\
\text { e Gestão de Empreendimentos na } \\
\text { Construçăo Civil }\end{array}$ & Especialista & Lato Sensu & São Paulo & CCC-SPO & 2015 \\
\hline $\begin{array}{c}\text { Especializaçăo em Projeto e } \\
\text { Tecnologia do Ambiente Construido }\end{array}$ & Especialista & Lato Sensu & São Paulo & CCC-SPO & 2015 \\
\hline $\begin{array}{c}\text { Especialização em Aeroportos - } \\
\text { Projeto e Construção }\end{array}$ & Especialista & Lato Sensu & São Paulo & CCC-SPO & 2015 \\
\hline Gestão em Energia & Elétrica & Energia & Estado SP & CEL-SPO & 2015 \\
\hline
\end{tabular}

No campus São Paulo, as propostas de cursos seguem a política educacional local, na qual as diretorias se mobilizam para propor cursos relacionados aos que são aplicados atualmente. As seis diretorias reúnem departamentos que abrigam modalidades de cursos similares. Essas diretorias se dividem em: Departamento de Informática e Turismo (DIT), 
Departamento de Ciência e Matemática (DCM), Departamento de Mecânica (DME), Departamento de Elétrica (DEL), Departamento de Humanidades (DHU) e Departamento de Construção Civil (DCC).

A proximidade da data final do PDI 2014-2018 somada à crise política e ampla redução orçamentária indicam que, de toda a listagem de cursos propostos ilustrada nos quadros de 8 a 12, ao final do período de vigência do plano, somente terão sido implementados os seguintes cursos: Técnico Integrado ao Ensino Médio em Telecomunicações; Mestrado Profissional em Ensino de Ciências e Matemática; Especialização em Aeroportos - Projeto e Construção; e Graduação em Arquitetura e Urbanismo. Curiosamente, o curso de Arquitetura e Urbanismo pertence à área de Ciências Sociais Aplicadas. No campus São Paulo, o curso em questão está ligado ao Departamento de Construção Civil e, em 2014, foi considerado o mais concorrido no Sistema de Seleção Unificado (Sisu) ${ }^{15}$.

Se as propostas dos quarenta cursos tivessem se concretizado no campus São Paulo, o número de cursos oferecidos pela instituição mais do que dobraria. Seriam 72 cursos de graus distintos no total.

Hoje, a estrutura física do campus ocupa área total ${ }^{16}$ de $57.448 \mathrm{~m}^{2}$ e área construída de $34.883 \mathrm{~m}^{2}$. Para atender ao PDI se propunha um projeto de melhorias da infraestrutura. Entretanto, o prédio idealizado não teve a construção aprovada pelos mesmos motivos que os cursos não efetivados. Sem a construção do prédio, dobrar o quantitativo de cursos e alunos dobraria as dificuldades, inclusive na Biblioteca.

Para comparar o PDI à missão da Biblioteca Francisco Montojos, tomemos como base o objetivo definido em 2008 pela própria:

A biblioteca tem a finalidade ${ }^{17}$ de oferecer suporte informacional aos programas de ensino, pesquisa e extensão e destina-se, primordialmente, a alunos regularmente

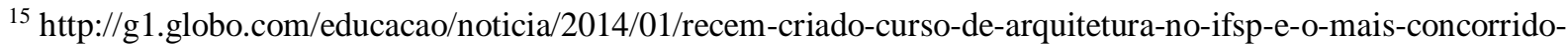
do-sisu.html

${ }^{16}$ https://spo.ifsp.edu.br/estrutura-fisica

17 https://spo.ifsp.edu.br/biblioteca?id=180
} 
matriculados em todos os níveis de ensino do Instituto, seus professores, servidores e a comunidade em geral para consultas in loco

Não existem documentos oficiais sobre a constituição da biblioteca do campus São Paulo, nem de forma conjunta pela rede do IFSP, nem de forma individualizada pelo campus. Isso mostra que a biblioteca é entendida como os demais setores institucionais do campus, não recebendo atenção especial quanto aos serviços prestados. Por isso, entendemos que a biblioteca definida em 2008 caminha em concordância com as finalidades e características dos IFs, segundo o Art. $6^{\circ}$ da Lei no 11.892 e o Relatório de Gestão (2016):

I - ofertar educação profissional e tecnológica, em todos os seus níveis e modalidades, formando e qualificando cidadãos com vistas na atuação profissional nos diversos setores da economia, com ênfase no desenvolvimento socioeconômico local, regional e nacional;

II - desenvolver a educação profissional e tecnológica como processo educativo e investigativo de geração e adaptação de soluções técnicas e tecnológicas às demandas sociais e peculiaridades regionais;

III - promover a integração e a verticalização da educação básica à educação profissional e educação superior, otimizando a infraestrutura física, os quadros de pessoal e os recursos de gestão;

IV - orientar sua oferta formativa em benefício da consolidação e fortalecimento dos arranjos produtivos, sociais e culturais locais, identificados com base no mapeamento das potencialidades de desenvolvimento socioeconômico e cultural no âmbito de atuação do Instituto Federal;

$\mathrm{V}$ - constituir-se em centro de excelência na oferta do ensino de ciências, em geral, e de ciências aplicadas, em particular, estimulando o desenvolvimento de espírito crítico, voltado à investigação empírica;

VI - qualificar-se como centro de referência no apoio à oferta do ensino de ciências nas instituições públicas de ensino, oferecendo capacitação técnica e atualização pedagógica aos docentes das redes públicas de ensino;

VII - desenvolver programas de extensão e de divulgação científica e tecnológica;

VIII - realizar e estimular a pesquisa aplicada, a produção cultural, o empreendedorismo, o cooperativismo e o desenvolvimento científico e tecnológico; IX - promover a produção, o desenvolvimento e a transferência de tecnologias sociais, notadamente as voltadas à preservação do meio ambiente.

Esmiuçando todos os tópicos apresentados, apontamos que essas finalidades convergem com o trabalho desenvolvido pela Biblioteca Francisco Montojos nos seguintes aspectos:

1. Atender a comunidade acadêmica em todos os seus níveis e modalidades da educação profissional e tecnológica. 
2. Auxiliar no processo educativo e investigativo de desenvolvimento da educação profissional e tecnológica.

3. Assessorar a promoção de integração e verticalização da educação básica à educação profissional e educação superior, por meio da infraestrutura física, dos quadros de pessoal e dos recursos de gestão.

4. Oferecer fontes de informação, no sentido de orientar ofertas formativas em benefício da consolidação e fortalecimento dos arranjos produtivos, sociais e culturais locais, identificados com base no mapeamento das potencialidades de desenvolvimento socioeconômico e cultural no âmbito de atuação do Instituto Federal.

5. Dispor de produtos e serviços voltados às ciências que possibilitem a constituição do IF em um centro de excelência na oferta do ensino de ciências, em geral, e de ciências aplicadas, em particular, estimulando o desenvolvimento de espírito crítico.

6. Amparar a qualificação do IF como centro de referência no apoio à oferta do ensino de ciências nas instituições públicas de ensino, oferecendo apoio com fontes de informação na capacitação técnica e atualização pedagógica aos docentes das redes públicas de ensino.

7. Participar do desenvolvimento de programas de extensão por meio de projetos que incluam a comunidade externa e executar a divulgação científica e tecnológica do IF.

8. Auxiliar na realização e no estimulo à pesquisa aplicada, à produção cultural, ao empreendedorismo, ao cooperativismo e ao desenvolvimento científico e tecnológico. 
9. Apoiar a promoção de produção e o desenvolvimento e a transferência de tecnologias sociais, notadamente as voltadas à preservação do meio ambiente.

Os objetivos dos Institutos Federais, definidos no Art. 7o da Lei $\mathrm{n}^{\circ} 11.892$ e repetidos no Relatório de Gestão 2016 do IFSP (IFSP, 2016), assemelham-se à finalidade dos IFs. Abaixo, alguns deles:

II - ministrar cursos de formação inicial e continuada de trabalhadores, objetivando a capacitação, o aperfeiçoamento, a especialização e a atualização de profissionais, em todos os níveis de escolaridade, nas áreas da educação profissional e tecnológica;

III - realizar pesquisas aplicadas, estimulando o desenvolvimento de soluções técnicas e tecnológicas, estendendo seus benefícios à comunidade

IV - desenvolver atividades de extensão de acordo com os princípios e finalidades da educação profissional e tecnológica, em articulação com o mundo do trabalho e os segmentos sociais, e com ênfase na produção, desenvolvimento e difusão de conhecimentos científicos e tecnológicos;

$\mathrm{V}$ - estimular e apoiar processos educativos que levem à geração de trabalho e renda e à emancipação do cidadão na perspectiva do desenvolvimento socioeconômico local e regional;

O Plano de Desenvolvimento Institucional (2014-2018) não cita os objetivos do IFSP, mas sim a missão descrita como "Construir uma práxis educativa que contribua para a inserção social, para a formação integradora e para a produção do conhecimento". A missão é definida como

[...] uma identidade construída a partir de referenciais ético-políticos, científicos e tecnológicos presentes nos seus princípios e diretrizes de atuação, que refletem a opção da Instituição em se envolver nas diversas demandas da sociedade, incluindo a escolarização daqueles que, no contexto da vida, não participaram das etapas regulares de aprendizagem. Acompanhando os processos de transformação no mundo do ensino e do trabalho, e com a perspectiva de diminuição das desigualdades sociais no Brasil. (Plano... 2014, p. 29).

É fato que documentos institucionais seguem a mesma direção, principalmente quando não existem documentos sobre a constituição da biblioteca. Considerando as definições de finalidade estabelecidas pela Biblioteca Francisco Montojos, entendemos que atendem os tópicos, mas não expressam a importância da mesma. Alguns profissionais da Biblioteca entendem que, mais do que oferecer suporte, ela precisa "propiciar aos seus usuários infraestrutura informacional necessária para as atividades da instituição e, assim, exercer 
atividades que oportunem o alcance da missão institucional" (SANTOS, BOCCATO e HOFFMANN, 2013, p. 65).

Conforme mencionado anteriormente, os esforços de todos os profissionais da Francisco Montojos foram direcionados na alimentação da representação descritiva no novo sistema, ou seja, concentraram-se no acervo. Enquanto isso, conforme informação disponível no site do campus São Paulo, a Biblioteca ofereceu os seguintes serviços: terminais de consulta ao acervo, cadastro de usuários externos, empréstimo, consulta local, renovação, reserva, elaboração de fichas catalográficas, visita orientada e assinaturas online.

Entendemos que, além da revisão de finalidade estabelecida pela Biblioteca, os serviços oferecidos precisam ser discutidos de acordo com o resultado apontado nos questionários. Afinal, os serviços pouco representam o potencial do serviço de referência, que, de acordo com Macedo (2005, p. 371), é o coração da biblioteca, é onde "recaem as funções de atendimento, orientação, divulgação, promoção e otimização do uso da biblioteca e ainda de atividades extensivas para a formação educativa, cultural e social dos estudantes”.

O PDI 2014-2018 faz uma única citação sobre serviços de biblioteca:

\begin{abstract}
"observando a necessidade de melhorias no oferecimento de serviços e produtos de qualidade pelas bibliotecas, pretende-se construir políticas consistentes de acesso à informação, que assegurem que seus usuários tenham o que precisem no momento em que precisem, seja no âmbito dos recursos tradicionais como no dos disponíveis em ambientes digitais." (Plano, 2014, p. 172)
\end{abstract}

A Política de Desenvolvimento de Coleções das Bibliotecas do IFSP não menciona nada sobre serviços ou serviços de referência.

A Política de Desenvolvimento de Coleções das Bibliotecas do IFSP não menciona nada sobre serviços ou serviços de referência.

O PDI contém 687 páginas e é produto de, pelo menos, três representantes de cada campus: um docente, um discente e um técnico administrativo - com exceção do campus São Paulo que, devido a seu tamanho e complexidade, reuniu três representantes de cada categoria, 
tendo o bibliotecário Natanael Benedito Amaro como um dos representantes dos técnicos administrativos.

O PDI está estruturado da seguinte maneira: Introdução; 1) Perfil Institucional - com os subcapítulos sobre a missão, o histórico institucional, a estrutura de cada um dos campi, inaugurações de campi programadas para os anos de 2014 e 2015, e os objetivos e metas da instituição; 2) Projeto Político Institucional; 3) Implementação da Instituição e Organização Acadêmica; 4) Corpo Docente; 5) Corpo Técnico-Administrativo; 6) Corpo Discente; 7) Organização Administrativa; 8) Avaliação Institucional; 9) Infraestrutura física, Instalações Acadêmicas e Acervo (Projeção); 10) Demonstrativo de Capacidade e Sustentabilidade Financeira; e 11) Considerações finais.

Verificamos que a palavra "biblioteca" é citada 101 vezes nos seguintes contextos:

- 1 (uma) vez para descrever as bibliotecas na estrutura geral dos IFs;

- 15 vezes ao se relatar a estrutura física das bibliotecas nos campi;

- 16 vezes no item “1.3.2 Pró-Reitoria de Ensino”, entidade à qual as bibliotecas estão submetidas - o item contém descrição do planejamento para a rede de bibliotecas, com objetivos gerais, objetivos específicos e metas sobre as quais discorreremos mais à frente;

- 1 (uma) vez no item "2.2 Princípios Filosóficos e Pedagógicos” - a biblioteca pública é citada como equipamento cultural de apoio aos docentes;

- 7 vezes no capítulo item "2.3 Políticas de Ensino", onde se reconhece a biblioteca como espaço de apoio ao desenvolvimento de ensino, pesquisa e extensão, declarando-se a necessidade de alinhamento das ações da biblioteca com as propostas pedagógicas dos cursos oferecidos pela instituição e o projeto de transformação das bibliotecas dos campi em bibliotecas comunitárias; 
- 61 vezes no “Capítulo 9 - Infraestrutura Física, Instalações Acadêmicas e Acervo (Projeção)”, com a descrição e o planejamento de cada campus.

Constata-se, na página 171, item “2.3 Politicas de Ensino”, que, embora o enfoque na oferta de cursos seja primordial, são necessárias atividades de educação formal e não formal integradas às atividades de extensão, da mesma forma que é necessário estimular atividades de pesquisa, fomentando-se a iniciação científica em todos os níveis. Para isso, é indispensável “contar com o apoio das bibliotecas as quais estão distribuídas por todos os campus do IFSP", pois "pelo enfoque na distribuição da informação e acesso aos mais diversos recursos informacionais, as bibliotecas têm sido planejadas com o intuito de serem centros difusores de conhecimentos que garantam a formação dos indivíduos de forma integral” (Plano... 2014, p. 171). Ideias consonantes com o documento Formação e Desenvolvimento de Coleções das Bibliotecas do IFSP, no qual se declara que "a formação adequada do acervo é necessária para o bom andamento das bibliotecas que atuam como subsídio teórico para as atividades de ensino, pesquisa e extensão do Instituto Federal de São Paulo, bem como atuam como suporte para o aparato investigativo de cada campus".

A Política de Desenvolvimento de Coleções das Bibliotecas do IFSP, publicada pela Portaria $n^{\mathrm{o}} 2.000$, de 6 de maio de 2014, tem, como objetivo geral, "direcionar de maneira coerente o desenvolvimento das coleções das bibliotecas do IFSP, atrelando esse processo aos objetivos do Instituto Federal de São Paulo”. Os objetivos específicos são:

- Normalizar o processo de seleção e aquisição de material bibliográfico;

- Orientar e direcionar o processo de seleção, em relação à quantidade e qualidade, de acordo com as características de cada curso oferecido pela instituição;

- Atualizar permanentemente o acervo, permitindo o crescimento racional e equilibrado do mesmo nas áreas de atuação da instituição;

- Atender a demanda informacional da comunidade acadêmica;

- Traçar diretrizes para o descarte de material;

- Nortear os procedimentos de avalição de coleções (Política.., 2014, p. 07) 
Os objetivos específicos "a" e "b" dialogam com o Capítulo 6 do mesmo documento: "Responsabilidade pela Política de Desenvolvimento de Coleções", onde se aponta que "o processo de seleção e aquisição de acervo é da responsabilidade dos bibliotecários dos campi do IFSP” (POLÍTICA... 2014, p. 9). Entendemos que, no campus São Paulo, a Biblioteca Francisco Montojos atua como parceira, e não como quem normaliza e direciona o processo de compra em sua integralidade, devido às especificidades dos setores que realizam atividades que contribuem para a aquisição. Dessa forma, cabe-nos orientar o que envolvem as especificidades dos trabalhos da Biblioteca, para não invadirmos a prerrogativa de outros profissionais.

Quanto aos objetivos específicos “e” e "f”, a Francisco Montojos está realizando avaliação do acervo baseada nos Projetos Pedagógicos de Curso e está em processo de avaliação dos materiais bibliográficos não indicados nos cursos pelos critérios definidos para o descarte de material da Política de Desenvolvimento de Coleções.

Esse conjunto de objetivos específicos também é considerado a partir da ótica do estudo de comunidade da Biblioteca, levando-se em conta as necessidades dos usuários, dos não usuários e dos usuários potenciais. Identificam-se os seguintes aspectos:

- o perfil socioeconômico da comunidade escolar;

- os materiais de informação utilizados pela comunidade escolar;

- o comportamento dos usuários da Biblioteca com relação à informação (preferência de formato, dificuldade de acesso, múltiplos aspectos culturais e educacionais);

- as necessidades informacionais dos usuários.

A biblioteca do campus São Paulo contempla quase todos os pontos indicados para o estudo da comunidade, baseando suas aquisições nas indicações referenciadas nos PPCs e no uso intenso dos materiais não indicados nos cursos. O único ponto que nunca foi utilizado para planejar aquisições no campus São Paulo é o perfil socioeconômico da comunidade escolar, 
devido ao amparo individualizado dos alunos em estado de vulnerabilidade ser parte das atribuições exercidas pela Diretoria Sociopedagógica do IFSP.

Retomando as discussões sobre o PDI 2014-2018, podemos declarar que o documento se preocupa com a aquisição e atualização de livros físicos e digitais, em acordo com o PPC, no item 1.3, “Objetivos e Metas da Instituição", e no Capítulo 9, "Infraestrutura Física, Instalações Acadêmicas e Acervo (Projeção)”.

Até a confecção do PDI, as aquisições eram realizadas de forma isolada pelas bibliotecas. Atualmente, as bibliotecas realizam aquisições em rede de livros eletrônicos, normas da ABNT, Periódicos Capes com assinatura de bases de dados adicionais, entre outros materiais, por meio da Coordenadoria de Bibliotecas da Reitoria. Somente a aquisição de livros impressos é realizada de forma independente por cada unidade.

No item 1.3 do PDI, um dos objetivos gerais da Pró-Reitoria de Ensino é: "Desenvolver políticas de gestão para as bibliotecas do IFSP", com o objetivo específico "Identificar as necessidades para a criação do Sistema de Bibliotecas”. Duas das metas desse objetivo são: “atualizar o acervo bibliográfico, em conformidade com os Projetos Pedagógicos de Cursos”; e "elaborar o projeto de aquisição e atualização do acervo bibliográfico conforme o Projeto Pedagógico de Curso". 
Quadro 13 - Objetivos e Metas do IFSP para acervos de 2014-2018

\begin{tabular}{|c|c|c|}
\hline $\begin{array}{l}\text { OBJETIVO } \\
\text { GERAL }\end{array}$ & \multicolumn{2}{|c|}{$\begin{array}{l}\text { Desenvolver políticas de gestão para as Bibliotecas do } \\
\text { IFSP. }\end{array}$} \\
\hline OBJETIVOS ESPECÍFICOS & METAS & EXECUÇÃO \\
\hline \multirow{8}{*}{$\begin{array}{l}\text { Identificar as necessidades } \\
\text { para a criação do Sistema } \\
\text { de Bibliotecas. }\end{array}$} & $\begin{array}{l}\text { Elaborar o projeto de criação do } \\
\text { Sistema de Bibliotecas. }\end{array}$ & 2014-2018 \\
\hline & $\begin{array}{l}\text { Implantar gradualmente o Sistema de } \\
\text { Bibliotecas do IFSP. }\end{array}$ & 2014-2018 \\
\hline & $\begin{array}{l}\text { Atualizar o acervo bibliográfico, em } \\
\text { conformidade com os Projetos } \\
\text { Pedagógicos de Cursos. }\end{array}$ & 2014-2018 \\
\hline & $\begin{array}{l}\text { Elaborar o projeto de aquisição e } \\
\text { atualização do acervo bibliográfico. }\end{array}$ & 2014-2018 \\
\hline & $\begin{array}{l}\text { Implementar um software } \\
\text { automação de bibliotecas para } \\
\text { unidades da rede. }\end{array}$ & 2014-2018 \\
\hline & $\begin{array}{l}\text { Acompanhar e gerenciar as demandas } \\
\text { apresentadas pelas unidades } \\
\text { relacionadas à implementação e ao } \\
\text { funcionamento do software de } \\
\text { automação de bibliotecas. }\end{array}$ & 2014-2018 \\
\hline & $\begin{array}{l}\text { Desenvolver programas de atualização } \\
\text { profissional para o pessoal de } \\
\text { bibliotecas (bibliotecários, auxiliares e } \\
\text { assistentes). }\end{array}$ & 2014-2018 \\
\hline & $\begin{array}{l}\text { Sistematizar os instrumentos que } \\
\text { regerão as ações do sistema de } \\
\text { bibliotecas. }\end{array}$ & 2014-2018 \\
\hline
\end{tabular}

No Capítulo 9, cada campus apresenta sua projeção de aquisição de livros. O campus São Paulo indica a seguinte projeção:

Quadro 14 - Acervo por área do conhecimento

\begin{tabular}{|c|c|c|c|c|c|c|c|c|}
\hline \multicolumn{2}{|r|}{ Item } & \multirow{2}{*}{$\begin{array}{c}\text { SituaçAo } \\
\text { atual - 2013 } \\
\text { (qtde.) }\end{array}$} & \multicolumn{5}{|c|}{$\begin{array}{c}\text { Situaça prevista } \\
\text { (acresscimo em quantidade por ano) }\end{array}$} & \multirow{2}{*}{$\begin{array}{c}\text { Total previste } \\
\text { para } 2018 \\
\text { (qtde.) }\end{array}$} \\
\hline Descriçao & Area do conhecimento & & 2014 & 2015 & 2016 & 2017 & 2018 & \\
\hline \multirow{5}{*}{ Livros } & Ciências Biológicas & 805 & 175 & 250 & 250 & 250 & 250 & 1.980 \\
\hline & Ciências Ambientais & 64 & 80 & 80 & 80 & 80 & 80 & 464 \\
\hline & Ciências agrárias & 66 & 10 & 10 & 10 & 10 & 10 & 114 \\
\hline & Ciências da Saúde & 755 & 60 & 60 & 60 & 60 & 60 & 1.055 \\
\hline & Ciências exatas e da Terra & 14.098 & 300 & 410 & 410 & 410 & 410 & 16.038 \\
\hline
\end{tabular}




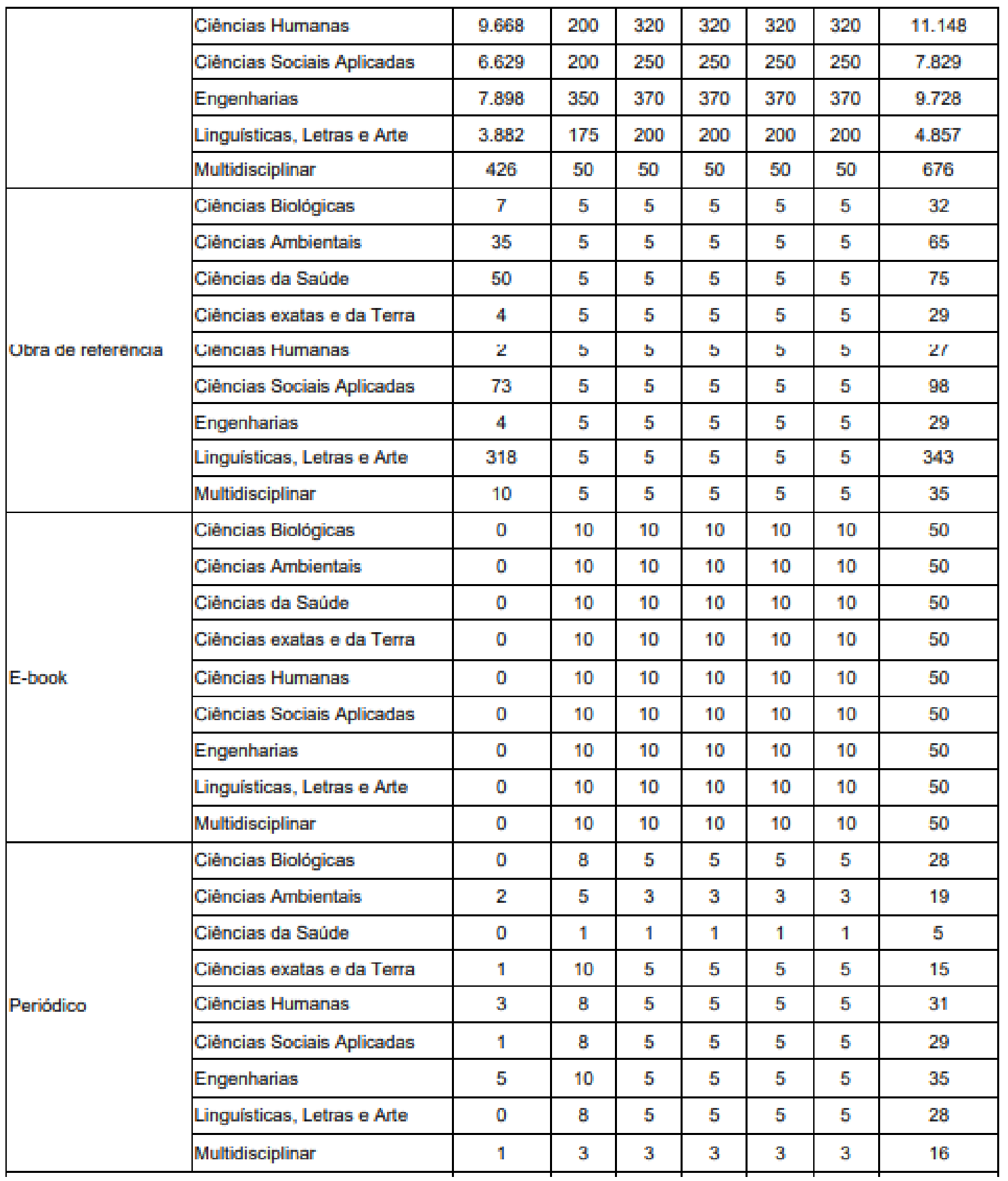

\begin{tabular}{|l|c|c|c|c|c|c|c|}
\hline Jornais & 0 & 2 & 1 & 1 & 1 & 1 & 6 \\
\hline Revista & 0 & 10 & 2 & 2 & 2 & 2 & 18 \\
\hline Assinatura eletrônica' & 150 & & & & & & 150 \\
\hline Normas² & 449 & & & & & & \\
\hline Computador & 6 & 8 & 5 & 5 & 5 & 5 & 39 \\
\hline Apostila & 883 & 5 & 5 & 5 & 5 & 5 & 908 \\
\hline CD-ROM & 100 & 25 & 25 & 25 & 25 & 25 & 225 \\
\hline \\
observaçaı
\end{tabular}


A aquisição no campus São Paulo, segundo o relatório do sistema Pergamum, foi de 1.619 títulos e 5.387 exemplares de 2015 a 2017. Anteriormente a 2015, não se registrava a data de aquisição nos exemplares. Por isso, no sistema Pergamum, não há registros do ano de 2014. Todos os livros sem identificação de data de aquisição foram registrados com uma data fictícia padrão anterior para facilitar o reconhecimento e futuro projeto de regularização.

Essas aquisições realizadas no período de vigência do PDI 2014-2018 abarcam muitos títulos e exemplares dos poucos cursos que se concretizaram dos propostos no documento. Reiteramos que o Plano foi elaborado antes da crise econômica e política, o que justifica a não aquisição dos materiais bibliográficos nas áreas de conhecimento dos cursos não implantados e a baixa aquisição nas áreas de conhecimento dos cursos já instituídos.

Embora o PDI indique um quantitativo para a compra de material bibliográfico, o orçamento para efetivar a compra depende da decisão do Conselho do Campus (Concam), que define por votação anual o montante a ser gasto. Assim, foi instituído o acervo para o curso de graduação em Arquitetura e Urbanismo, parte da atualização das bibliografias indicadas pelas áreas até 2017 e outros materiais bibliográficos. Os demais cursos novos não realizaram solicitações de compra. Em 2018, o valor a ser gasto em materiais bibliográficos foi definido pelo Concam em R \$ 80 mil, quantia semelhante à do anos anteriores. No entanto, o valor final orçado e aprovado pela diretoria foi de R $\$ 180$ mil. É importante mencionar que o bibliotecário Natanael Benedito Amaro faz parte do Concam como representante técnico-administrativo, o que permite abordar questões da Biblioteca naquele espaço.

Na Política de Desenvolvimento de Coleções das Bibliotecas do IFSP, declara-se que a aquisição deve estar alinhada aos objetivos institucionais e acadêmicos. A "aquisição de materiais, abrangendo obras de referência, livros, periódicos e multimeios deve ser norteada por uma política cujos objetivos da instituição e da comunidade acadêmica sejam balizadores". 
A informação descrita de que a política local precisa obedecer aos desígnios institucionais e do público que integra o espaço dialoga com nossa proposta de objetivo geral.

Para a aquisição por compra, a Política de Desenvolvimento de Coleções avalia que "faz-se necessária a utilização de instrumentos metodológicos a fim de investigar e identificar as características, interesses e necessidades da comunidade acadêmica, como, por exemplo, o uso de questionário eletrônico, que auxilia na tabulação e manipulação dos dados" para a realização de um estudo de usuários que identifique as carências. Os instrumentos metodológicos que utilizamos no campus São Paulo que justificam as aquisições por compra de referências indicadas pela Biblioteca estão ligados aos interesses manifestados pelos usuários no balcão de atendimento, nos e-mails, no sistema da Biblioteca, entre outros. Para contemplar as bibliografias indicadas nos 32 cursos, as coordenações de cada curso encaminham as referências que precisam ser adquiridas para atender os usuários.

Para realizar a aquisição, são necessários critérios de seleção para materiais bibliográficos. A Política de Desenvolvimento de Coleções aponta os seguintes critérios de seleção: autoridade, atualidade do acervo, cobertura, precisão, imparcialidade, custo, idioma, relevância/interesse, durabilidade, acesso e suporte na aquisição. Estes são aplicados nas referências indicadas pela Biblioteca na aquisição de literaturas de conhecimentos gerais, gêneros literários distintos e complementação de quantidades, mas são indicações que não chegam a um quinto da compra anual, quando ocorrem. Tanto é que, no ano de 2018, não há nenhuma indicação da Biblioteca na aquisição do material orçado em $\mathrm{R} \$ 180$ mil reais.

O maior quantitativo de indicações de compra no campus São Paulo são as referências indicadas pelas coordenações de curso que estão ligadas diretamente às bibliografias listadas nos PPCs. Os PPCs são documentos constituídos pelas coordenadorias de curso, juntamente com o Núcleo Docente Estruturado (NDE), instituído periodicamente. A Resolução 79/2016 do IFSP, de 6 de setembro de 2016, oficializou o último NDE, descrevendo-o como órgão 
consultivo e de assessoramentos dos cursos: "É constituído por docentes, com atribuições acadêmicas de acompanhamento, atuante no processo de concepção, consolidação e contínua atualização do PPC". Os critérios adotados para a seleção dos títulos são determinados por esses sujeitos. Não cabe à Biblioteca avaliar as referências segundo os critérios de seleção apontados no documento da política de bibliotecas, tendo em vista o grupo especializado formado com esse objetivo. Devemos mencionar que, caso a seleção ficasse sob responsabilidade dos bibliotecários, como diz a Política de Desenvolvimento de Coleções, a equipe de cinco funcionários, em meio a 32 cursos, não daria conta de indicar referências a áreas tão distintas.

Para o processo de aquisição, o documento de desenvolvimento de coleções sugere uma comissão consultiva formada pelos bibliotecários e coordenadores das áreas de especificidades de cada campus do instituto, a ser designada por portaria pelo diretor geral do campus. No campus São Paulo, ocorre algo parecido com uma comissão consultiva. O processo de aquisição inicia na Diretoria Administrativa, que publica documentos que devem receber, juntamente com as referências e um cronograma que precisa ser cumprido pelas coordenadorias dos cursos e pela biblioteca. De maneira geral, a aquisição por compra no campus São Paulo passa pelos setores: Coordenações, Biblioteca, Diretoria Administrativa, Almoxarifado, Financeiro e Patrimônio, para só então o material bibliográfico comprado chegar ao seu destino: a Biblioteca. Cada processo de aquisição completo não ocorre em menos de um ano. Em razão disso, com o objetivo de mapear os processos e empregar transparência, a Biblioteca Francisco Montojos organizou, por meio de construção coletiva com os setores envolvidos já listados, um documento que complementa a Política de Desenvolvimento de Coleções das Bibliotecas do IFSP, direcionado às especificidades relacionadas ao campus São Paulo. Esse documento também atua como um manual, exibindo um passo a passo com orientações a todos os participantes ligados a esse processo. 
A Política de Desenvolvimento de Coleções também informa que a compra de materiais para o acervo da Biblioteca deve ser feita por licitação - em conformidade com a Constituição Federal, Art. 37, Inciso XXI, e com o Art. $2^{\circ}$ da Lei $n^{\circ}$ 8.666/93, que institui normas para licitações e contratos da Administração Pública e dá outras providências. Com exceção da alienação de bens (Art. 17, Lei nº 8.666/93), dispensa de licitação (Art. 24, Lei nº 8.666/93), e inexigibilidade de licitação (Art. 25, Lei no 8.666/93). Até antes de 2016, a licitação era realizada por pregão eletrônico. No ano de 2017, um grupo de bibliotecários do IFSP conseguiu formalizar o Sistema de Registro de Preços (Decreto $n^{\circ} 7.892 / 2013$, Art. $3^{\circ}$, Incisos de I a IV) baseados nos seguintes argumentos, que legitimam o uso.

\footnotetext{
i.Quando, pelas características do bem ou serviço, houver necessidade de contratações frequentes;

ii.Quando for conveniente a aquisição de bens com previsão de entregas parceladas ou contratação de serviços remunerados por unidade de medida ou em regime de tarefa; iii.Quando for conveniente a aquisição de bens ou a contratação de serviços para atendimento a mais de um órgão ou entidade, ou a programas de governo; ou

iv.Quando, pela natureza do objeto, não for possível definir previamente o quantitativo a ser demandado pela Administração (BRASIL, 2013, não paginado).
}

Nessa modalidade, foram realizadas as aquisições por compra nos anos de 2017 e 2018. Os trabalhos realizados pela Biblioteca são apresentados no fluxograma abaixo, com a descrição de todas as etapas por que passam os livros frutos de aquisição por compra de indicações dos coordenadores. 
Figura 8 - Fluxograma da aquisição por compra das indicações das coordenações de curso

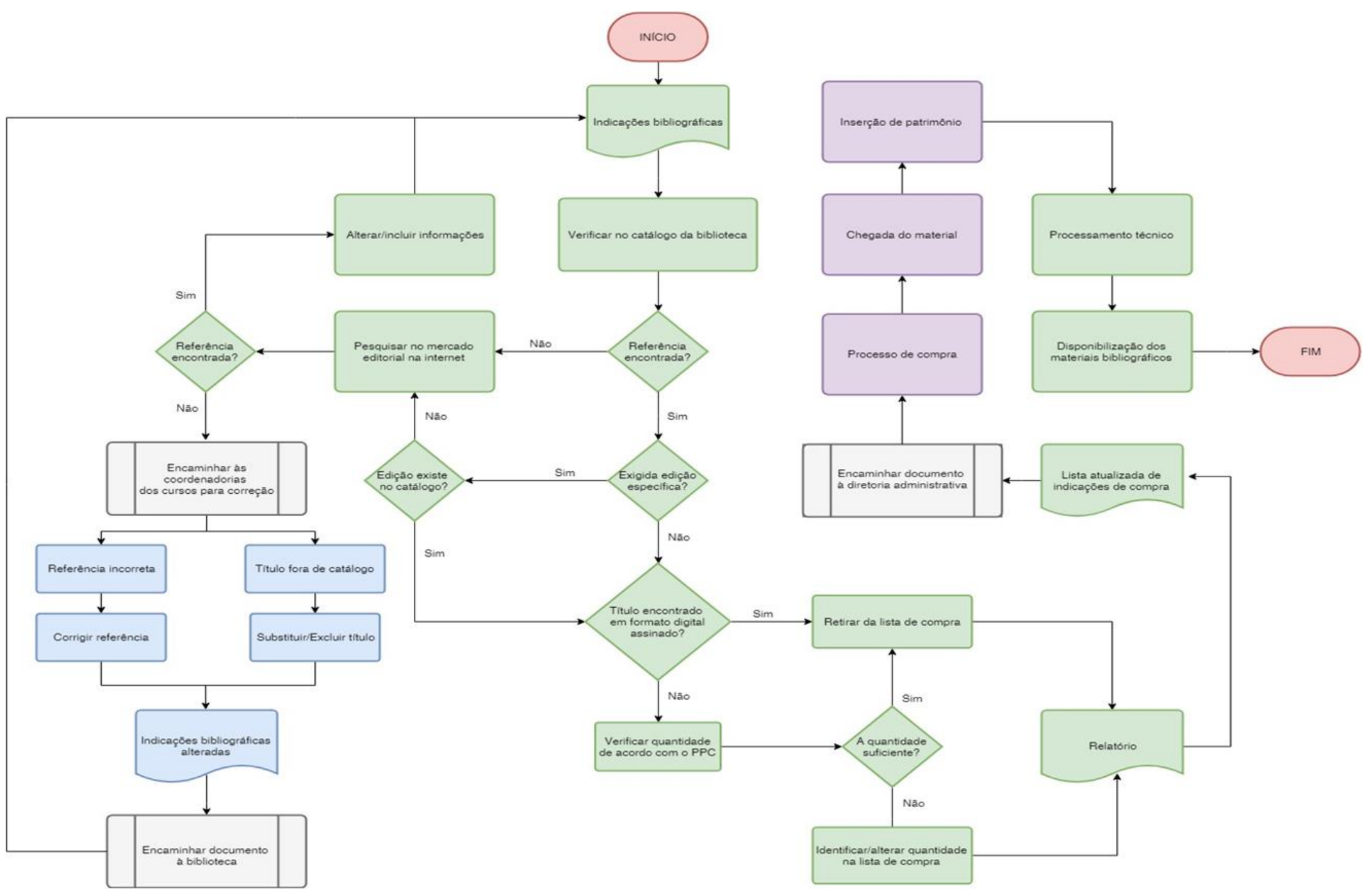

Fonte: Elaborado por Ricardo Alves Pedro Junior e Rebeca Lilian Rodrigues 
As bibliotecas dos IFs não realizam permuta e as doações seguem o documento de formação e desenvolvimento de coleções. “O processamento técnico e incorporação no acervo dos itens recebidos por doação serão realizados segundo os tramites normais dos demais itens da biblioteca, ou seja, de acordo com as necessidades dos usuários e disponibilidade da equipe técnica". Os doadores são informados sobre os critérios estabelecidos pela biblioteca que suscitam interesse para serem aceitos.

Todos os três formatos de aquisição são considerados bens permanentes da instituição e incorporados pela Coordenadoria de Patrimônio do campus, o que promove algumas situações delicadas.

A primeira, talvez, afete apenas o campus São Paulo, devido ao grande volume de compra dessa unidade. Diz respeito à entrada dos materiais bibliográficos físicos na instituição. A aquisição por compra gera o número de pelos menos 2 mil exemplares por ano que são patrimoniados individualmente. O processo de compra é demorado, independentemente do tipo de licitação aplicada. O tempo de aquisição e inserção dos itens no acervo, o que inclui o processo de inserção patrimonial individual dos livros, pode durar de um a dois anos. Como mencionado no Referencial Teórico, essa decisão de se patrimoniar exemplares está baseada na Lei Federal n ${ }^{\circ}$ 4.320, de 17 de março de 1964, Art. 2º, Parágrafo 2: "Para efeito de classificação da despesa, considera-se material permanente o de duração superior a dois anos”.

Outro ponto delicado é a saída dos exemplares. Para os cursos superiores, a Biblioteca Francisco Montojos utiliza a tipologia universitária, na qual concentra seus esforços na avaliação do acervo e no descarte de materiais bibliográficos. Afinal, o desfazimento do setor de patrimônio acrescenta mais processos ao descarte quando os materiais físicos estão na Biblioteca. Para casos de livros extraviados, o coordenador responsável pela Biblioteca justifica as perdas por meio de processo administrativo e solicita algo similar ao "perdão" do reitor. 
Nesse caso, fica a critério do reitor acatar a justificativa do coordenador ou decidir pelo pagamento dos bens apontados.

Outro tópico pertinente abordado no PDI 2014-2018, item 1.3, “Objetivos e Metas da Instituição", é o objetivo específico de conversão das bibliotecas da rede do IFSP em bibliotecas comunitárias. A instauração da biblioteca comunitária traria vantagens, como autonomia e a possibilidade de se utilizar a Lei Federal $n^{\circ}$ 10.753, que institui a Política Nacional do Livro, segundo a qual o livro é considerado material de consumo.

Quadro 15 - Objetivos e Metas do IFSP para bibliotecas de 2014-2018

\begin{tabular}{|c|c|c|c|}
\hline $\begin{array}{l}\text { OBJETIVO } \\
\text { GERAL }\end{array}$ & \multicolumn{3}{|c|}{$\begin{array}{l}\text { Articular ações de extensão para a promoção do desenvolvimento } \\
\text { socioeconômico, político e cultural local e regional }\end{array}$} \\
\hline \multicolumn{2}{|c|}{ OBJETIVOS ESPECÍFICOS } & METAS & EXECUÇÃO \\
\hline \multirow{2}{*}{\multicolumn{2}{|c|}{$\begin{array}{l}\text { Ampliar os recursos de editais } \\
\text { voltados às ações socioculturais }\end{array}$}} & $\begin{array}{l}\text { Direcionar recursos para } \\
\text { editais que fomentem } \\
\text { projetos socioculturais, } \\
\text { inclusive esportivos }\end{array}$ & $2014-2018$ \\
\hline & & $\begin{array}{l}\text { Promover eventos abertos à } \\
\text { comunidade externa }\end{array}$ & $2014-2018$ \\
\hline \multirow{3}{*}{\multicolumn{2}{|c|}{$\begin{array}{lll}\text { Apoiar a transformação } & \text { das } \\
\text { bibliotecas dos campi } & \text { em } \\
\text { bibliotecas comunitárias } & \end{array}$}} & $\begin{array}{l}\text { Diagnosticar a atuação das } \\
\text { Bibliotecas em parceria com a } \\
\text { Coordenação de Bibliotecas }\end{array}$ & 2014 \\
\hline & & $\begin{array}{l}\text { Elaborar projeto base de } \\
\text { transição para Bibliotecas } \\
\text { Comunitárias }\end{array}$ & 2015 \\
\hline & & $\begin{array}{l}\text { Implantar projeto de } \\
\text { transição para Bibliotecas } \\
\text { Comunitárias, respeitando o } \\
\text { contexto local }\end{array}$ & $2016-2018$ \\
\hline \multicolumn{2}{|l|}{$\begin{array}{l}\text { Desenvolver } \\
\text { social }\end{array}$} & $\begin{array}{l}\text { Estabelecer diretrizes para } \\
\text { implantação da política } \\
\text { desenvolvimento } \\
\text { de }\end{array}$ & \\
\hline
\end{tabular}

Fonte: PDI

É importante mencionar que a unidade do IFSP de São João da Boa Vista utiliza a nomenclatura Biblioteca Comunitária Wolgran Junqueira desde sua inauguração em 2008, mas está vinculada ao campus, assim como as demais.

Diante dos aspectos observados, muitas discussões são necessárias se para analisarem as vantagens e desvantagens da conversão das bibliotecas do IFSP em bibliotecas comunitárias. 
Entretanto, até o início de 2018, as metas "Elaborar projeto base de transição para Bibliotecas Comunitárias" e "Implantar projeto de transição para Bibliotecas Comunitárias, respeitando o contexto local" não avançaram, e, na Política de Desenvolvimento de Coleções das Bibliotecas do IFSP, não existe nenhuma menção a essa mudança.

Entendemos que, caso seja retomada a ideia de conversão, será necessário discutir o assunto profundamente por meio de estudos da missão, dos serviços e do público que seria atendido por esse novo tipo de biblioteca, para se avaliar se é realmente necessária e viável a mudança.

Enquanto isso, conforme demostra a análise dos questionários a seguir, precisamos realizar diversas melhorias para se atingir um grau de qualidade no atendimento da comunidade acadêmica presente.

\subsection{ANÁLISE DOS QUESTIONÁRIOS}

O desenvolvimento do questionário foi fundamentado nos temas que identificam a vinculação institucional do participante, como ele se relaciona com o espaço da Biblioteca Francisco Montojos, a coleção e os serviços relacionados.

Dos cinquenta participantes, somente um estudante deixou de responder às questões, $o$ que fez com que o público analisado se mantivesse estável. Nenhuma das questões exigiam resposta obrigatória.

Analisemos individualmente as questões: 
Questão 1: "Indique seu vínculo com o IFSP - Campus São Paulo". O maior índice de resposta foi de alunos (88\%), seguidos por servidores técnico-administrativos $(10 \%)$ e docentes (2\%). Os números refletem o engajamento do grupo de alunos na divulgação do questionário em grupos específicos e fechados e nas mídias sociais.

Nenhum funcionário terceirizado participou da pesquisa. O motivo, consideramos, foi o número reduzido de representantes dessa categoria no instituto em comparação com as demais. Os funcionários terceirizados são a única categoria a não ter nenhum grupo específico nas redes sociais e e-mails de rede.

Gráfico 6 - Vínculo da comunidade com o IFSP

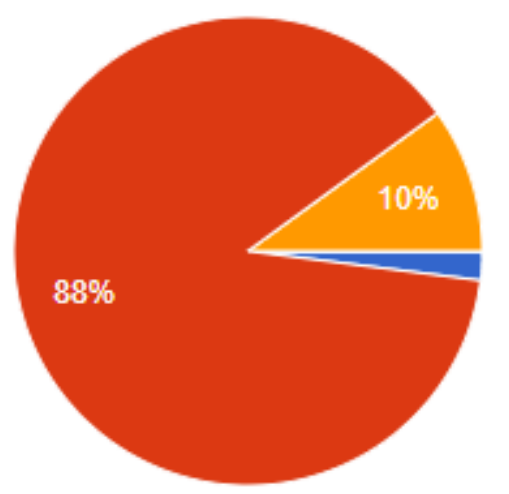

Docente

Aluno

Técnico Administrativo

Funcionário terceirizado

Fonte: Formulário Google 
Questão 2: “Aluno, em qual categoria você está inserido?”. A categoria mais participativa foi a dos alunos da graduação (47\%). Os discentes com vínculo único com a pósgraduação não participaram deste questionário.

Gráfico 7 - Identificação de categoria de cursos

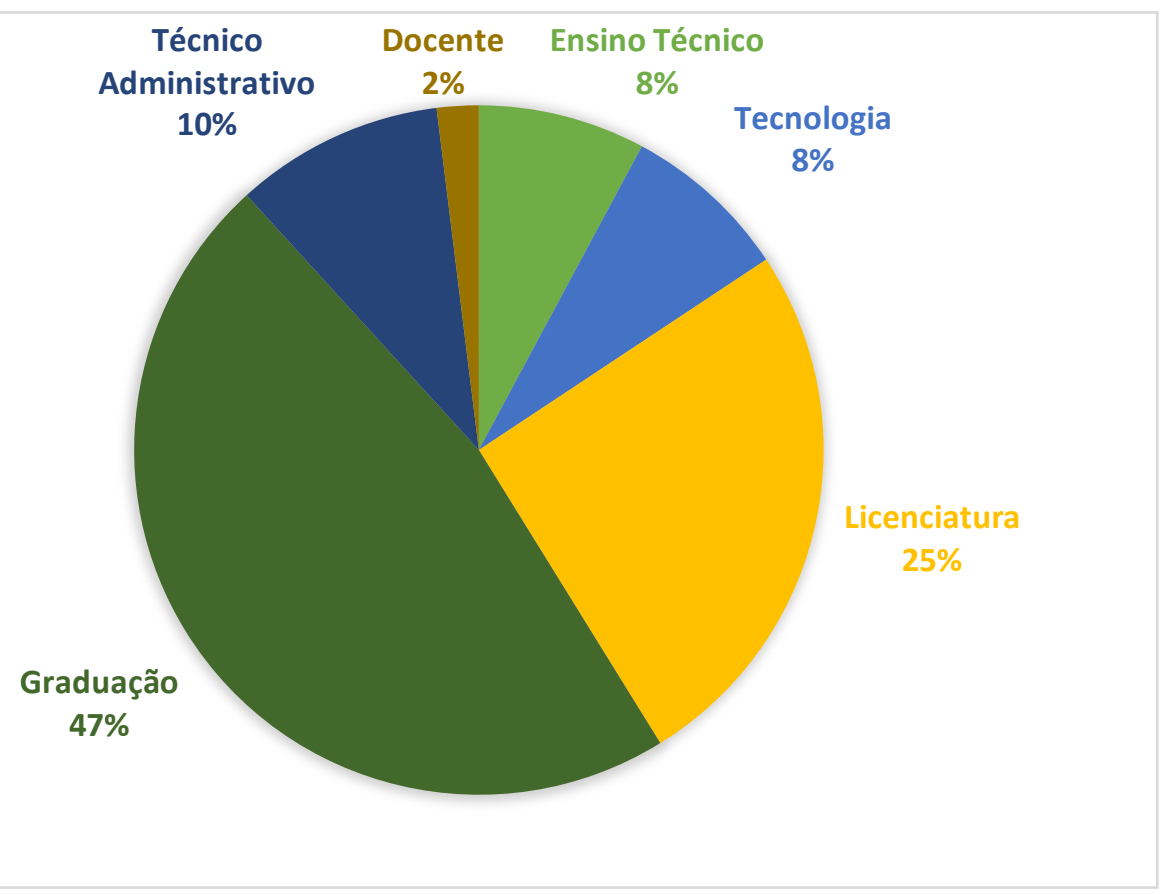

Fonte: Elabora pela autora

A tabela 2 apresenta a categorização dos participantes no Gráfico 7.

Tabela 2- Identificação de categoria de cursos

\begin{tabular}{|r|l|}
\hline Vinculações institucionais & Número de respostas \\
\hline Ensino Técnico & 4 \\
\hline Tecnologia & 3 \\
\hline Licenciatura & 13 \\
\hline Graduação & 24 \\
\hline Mestrado & 1 \\
\hline
\end{tabular}

Fonte: Elabora pela autora

Os estudantes identificaram seus cursos em 45 respostas. Curiosamente, dos cinco servidores técnico-administrativos que responderam, um se identificou como estudante de mestrado no próprio campus e dois como discentes de outras instituições. Sendo assim, para 
não duplicar informações, nas demais questões, consideraremos suas respostas como da categoria de servidores técnico-administrativos, tendo em vista que o fato desses estudantes serem servidores modifica sua relação com a Biblioteca ao refletir suas necessidades informacionais naquele espaço. 
Questão 3: "Você utiliza a Biblioteca?". A intenção foi medir o uso e a frequência dos participantes da pesquisa no espaço da Biblioteca para entendermos quem são os usuários. A opção “Às vezes” foi marcada por 38\% dos respondentes e foi o maior número de resposta entre todas as categorias, exceto no caso dos estudantes dos cursos de licenciatura, que indicaram o mesmo número de respostas entre as opções Sempre" e “Às vezes”. Assim, podemos concluir que a Biblioteca não conserva usuários assíduos, mas tem os públicos da licenciatura e graduação como mais frequentes.

Gráfico 8 - Utilização da biblioteca

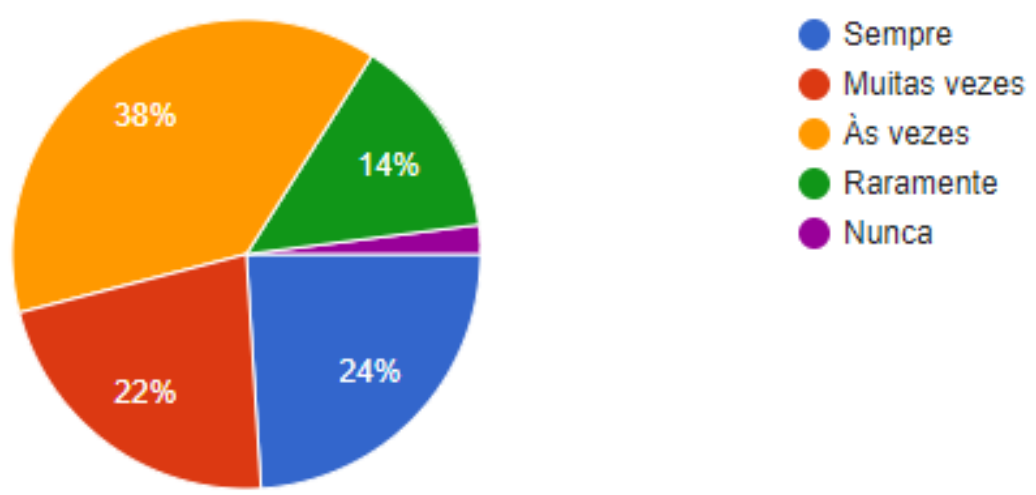

Fonte: Formulário Google

A tabela 3 apresenta a categorização dos participantes no gráfico 8 .

Tabela 3 - Utilização da Biblioteca dividida por categorias de alunos

\section{Ensino Tecnologia Licenciatura Graduação Técnico Docente Técnico Administrativo}

\begin{tabular}{|r|c|c|c|c|c|c|} 
Sempre & & & 4 & 7 & 1 & \\
\cline { 2 - 7 } Muitas vezes & 1 & & 4 & 4 & 1 & 1 \\
\cline { 2 - 7 } Às vezes & 2 & 1 & 4 & 10 & 2 & \\
Raramente & 1 & 1 & 2 & 2 & 1 & \\
\cline { 2 - 7 } Nunca & & 1 & & & & \\
\cline { 2 - 7 } & & & &
\end{tabular}

Fonte: Elabora pela autora 
Questão 4: "Em qual contexto você utiliza o salão de estudos da Biblioteca?". Os dados nos permitem perceber que o grupo que mais utiliza o salão para estudo individual com material emprestado da Biblioteca é o de alunos dos cursos superiores. Os que menos utilizam são os discentes do ensino técnico e as duas categorias de servidores.

Todos os estudantes, mesmo que em menor grau, utilizam o salão para estudo individual com material próprio, e somente os estudantes de licenciatura utilizam o salão para "estudo em grupo com material emprestado da Biblioteca".

Concluímos que os alunos do ensino técnico e os de licenciatura usam o espaço do salão para estudo em grupo com material próprio. Os discentes dos cursos de tecnologia e graduação indicaram que não utilizam o salão, assim como os servidores técnico-administrativos e o docente(apenas um docente respondeu ao questionário).

Gráfico 9 - Uso do salão da Biblioteca

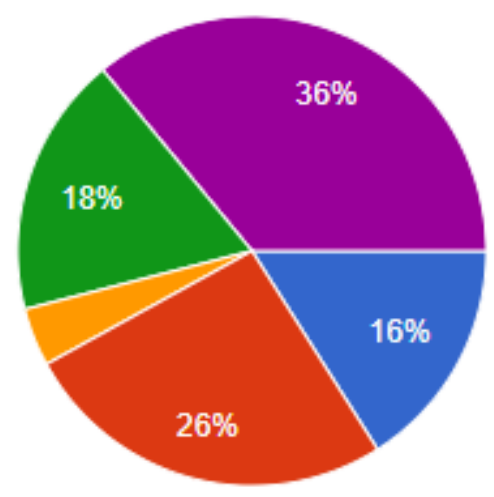

estudo individual com material emprestado da biblioteca

estudo individual com material próprio

estudo em grupo com material emprestado da biblioteca

- Estudo em grupo com material próprio

Não utilizo

Fonte: Formulário Google

A tabela 4 apresenta a categorização dos participantes no gráfico 9.

Tabela 4 - Uso do salão da Biblioteca

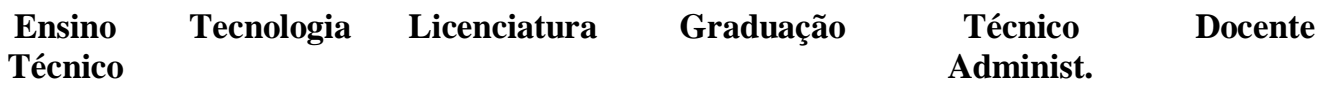

\begin{tabular}{|r|l|l|l|l|l|l|}
\hline $\begin{array}{r}\text { Estudo individual com } \\
\text { material emprestado da } \\
\text { biblioteca }\end{array}$ & & 1 & 2 & 5 & & \\
\cline { 2 - 5 } & & & & & & \\
\hline
\end{tabular}




\begin{tabular}{|c|c|c|c|c|c|c|}
\hline $\begin{array}{r}\text { Estudo individual com } \\
\text { material próprio }\end{array}$ & 1 & 1 & 5 & 6 & & \\
\hline $\begin{array}{r}\text { Estudo em grupo com } \\
\text { material emprestado da } \\
\text { biblioteca }\end{array}$ & & & 2 & & & \\
\hline $\begin{array}{r}\text { Estudo em grupo com } \\
\text { material próprio }\end{array}$ & 3 & & 1 & 5 & & \\
\hline Não utilizo & & 2 & 3 & 7 & 5 & 1 \\
\hline
\end{tabular}

Fonte: Elabora pela autora 
Questão 5: "Você gostaria de sugerir outro contexto de uso para o salão de estudos da Biblioteca?". A pergunta, aberta, recebeu as dez respostas listadas acima, elaboradas por nove discentes dos cursos superiores e um servidor técnico-administrativo. As respostas "Com baias para tornar mais fácil a concentração"; "Aquele local deveria ser a própria biblioteca"; "Mais salas de estudo compartilhadas, nas quais a discussão entre os grupos não gerasse incômodo aos outros estudantes"; e "A divisão entre espaços de debates e conversação e o de estudos" refletem a preocupação do ensino superior com a divisão física da Biblioteca entre o espaço de estudo individualizado, que requer silêncio, e o espaço de estudo em grupo, para debates e conversações. Um dos participantes entende que a Biblioteca precisa mediar discussões importantes, que contribuam com os temas acadêmicos, e outro cita a possibilidade de dormir.

Em torno do serviço de referência, um técnico administrativo indica a necessidade de treinamento em serviços e o aluno de um dos cursos tecnológicos a necessidade de computadores. Os computadores estão previstos para depois da reforma da Biblioteca, e os treinamentos associados aos serviços de referência estão em planejamento.

Quadro 16 - Contexto de uso para o salão de estudos

\begin{tabular}{|l|l|}
\hline \multirow{3}{*}{ Tecnologia } & Computadores \\
\cline { 2 - 2 } & Com baias para tornar mais fácil a concentração \\
\hline \multirow{3}{*}{ Licenciatura } & Debates e discussões importantes ou sobre temas acadêmicos \\
\cline { 2 - 2 } & Não \\
\cline { 2 - 2 } & Dormir \\
\cline { 2 - 2 } & Aquele local deveria ser a própria biblioteca \\
\cline { 2 - 2 } & Assim está bom \\
\hline \multirow{3}{*}{ Graduação } & $\begin{array}{l}\text { Mais salas de estudo compartilhado, nas quais a discussão entre os } \\
\text { grupos não gerasse incômodo aos outros estudantes }\end{array}$ \\
\cline { 2 - 2 } & A divisão entre espaços de debates e conversação e o de estudos \\
\hline Técnico & $\begin{array}{l}\text { Sim, para além dos estudos, atividades de treinamento dos serviços } \\
\text { Administrativo }\end{array}$ \\
\hline
\end{tabular}


Questão 6: “Com qual finalidade você utiliza o acervo da Biblioteca?”. A opção "Suporte aos trabalhos acadêmicos exigidos pelos cursos" recebeu o maior número de respostas das categorias ensino técnico, licenciatura, graduação e docente. Entre os estudantes dos cursos de tecnologia, o item "Recurso à pesquisa científica para o desenvolvimento de um estudo vinculado ao IFSP” foi o que recebeu o maior número de respostas.

Nenhuma das categorias escolheu a opção "Apoio aos estudos destinados à concursos públicos". Em número reduzido, representantes de todas as categorias escolheram "Desenvolvimento de Trabalho de Conclusão de Curso/Monografia/Dissertação", incluindo dois técnicos administrativos. A opção "Auxílio aos programas de extensão da instituição de ensino" também foi assinalada em número reduzido por todas as categorias - menos a dos cursos de licenciatura.

Na opção "Outros", com abertura para respostas livres, os estudantes de licenciaturas escreveram: "Estudar com os livros requisitados pro curso" e "Estudar pelos livros os conteúdos das provas". Consideramos que essas respostas estão ligadas à opção "Suporte aos trabalhos acadêmicos exigidos pelos cursos", mas é necessário reconhecer que a palavra "trabalho", talvez, tenha restringido a escolha, por não representar os alunos que utilizam os materiais para estudos livres e para provas.

Gráfico 10 - Finalidade de uso do acervo

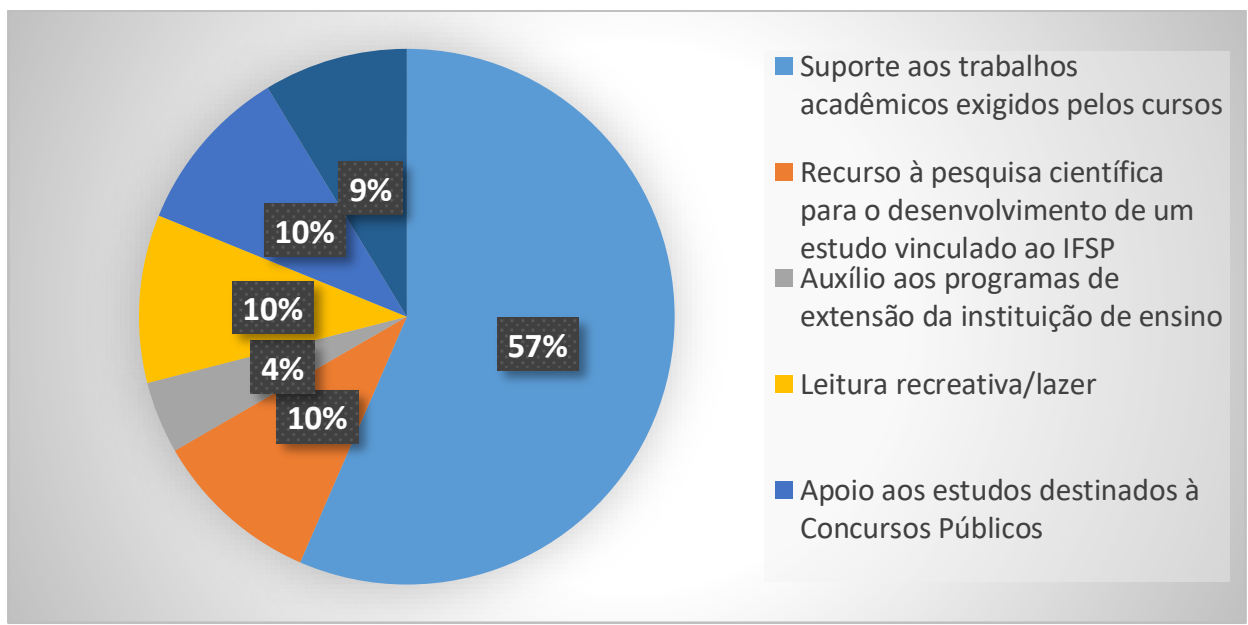

Fonte: Elabora pela autora 
O Gráfico 11 apresenta a categorização dos participantes no Gráfico 10.

Gráfico 11 - Finalidade de uso do acervo dividido por categorias de usuários

Suporte aos trabalhos acadêmicos exigidos..

Recurso à pesquisa científica Auxílio aos programas de extensão da..

Leitura recreativa/lazer

Apoio aos estudos destinados à Concursos.. Desenvolvimento de Trabalho de Conclusão...

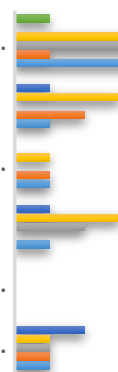

0

5

10

15

20

25

\begin{tabular}{|c|c|c|c|c|c|c|}
\hline & $\begin{array}{l}\text { Desenvolvime } \\
\text { nto de } \\
\text { Trabalho de } \\
\text { Conclusão de }\end{array}$ & $\begin{array}{l}\text { Apoio aos } \\
\text { estudos } \\
\text { destinados à } \\
\text { Concursos } \\
\text { Públicos }\end{array}$ & $\begin{array}{c}\text { Leitura } \\
\text { recreativa/laze } \\
r\end{array}$ & $\begin{array}{l}\text { Auxílio aos } \\
\text { programas de } \\
\text { extensão da } \\
\text { instituição de } \\
\text { ensino }\end{array}$ & $\begin{array}{l}\text { Recurso à } \\
\text { pesquisa } \\
\text { científica }\end{array}$ & $\begin{array}{l}\text { Suporte aos } \\
\text { trabalhos } \\
\text { acadêmicos } \\
\text { exigidos pelos } \\
\text { cursos }\end{array}$ \\
\hline Docente & & & & & & 1 \\
\hline - Técnico Adminst. & 2 & & 1 & & 1 & \\
\hline Graduação & 1 & & 3 & 1 & 3 & 21 \\
\hline Licenciatura & 1 & & 2 & & & 10 \\
\hline Tecnologia & 1 & & & 1 & 2 & 1 \\
\hline Ensino técnico & 1 & & 1 & 1 & 1 & 4 \\
\hline
\end{tabular}

Fonte: Elabora pela autora 
Questão 7: "Na biblioteca do campus São Paulo, você procura com mais frequência que tipo de material?". Os materiais bibliográficos ligados aos cursos correspondem a $75 \%$ das respostas, divididas entre as opções "Apenas as referências apontadas na bibliografia dos cursos" e "Materiais para pesquisa dos temas relacionados aos cursos". As duas opções tiveram quase a mesma proporção de respostas - os números relacionados à primeira foram levemente superiores nos cursos de licenciatura e graduação. O item "Outros" não foi escolhido por nenhum dos participantes.

Gráfico 12 - Tipo de material procurado

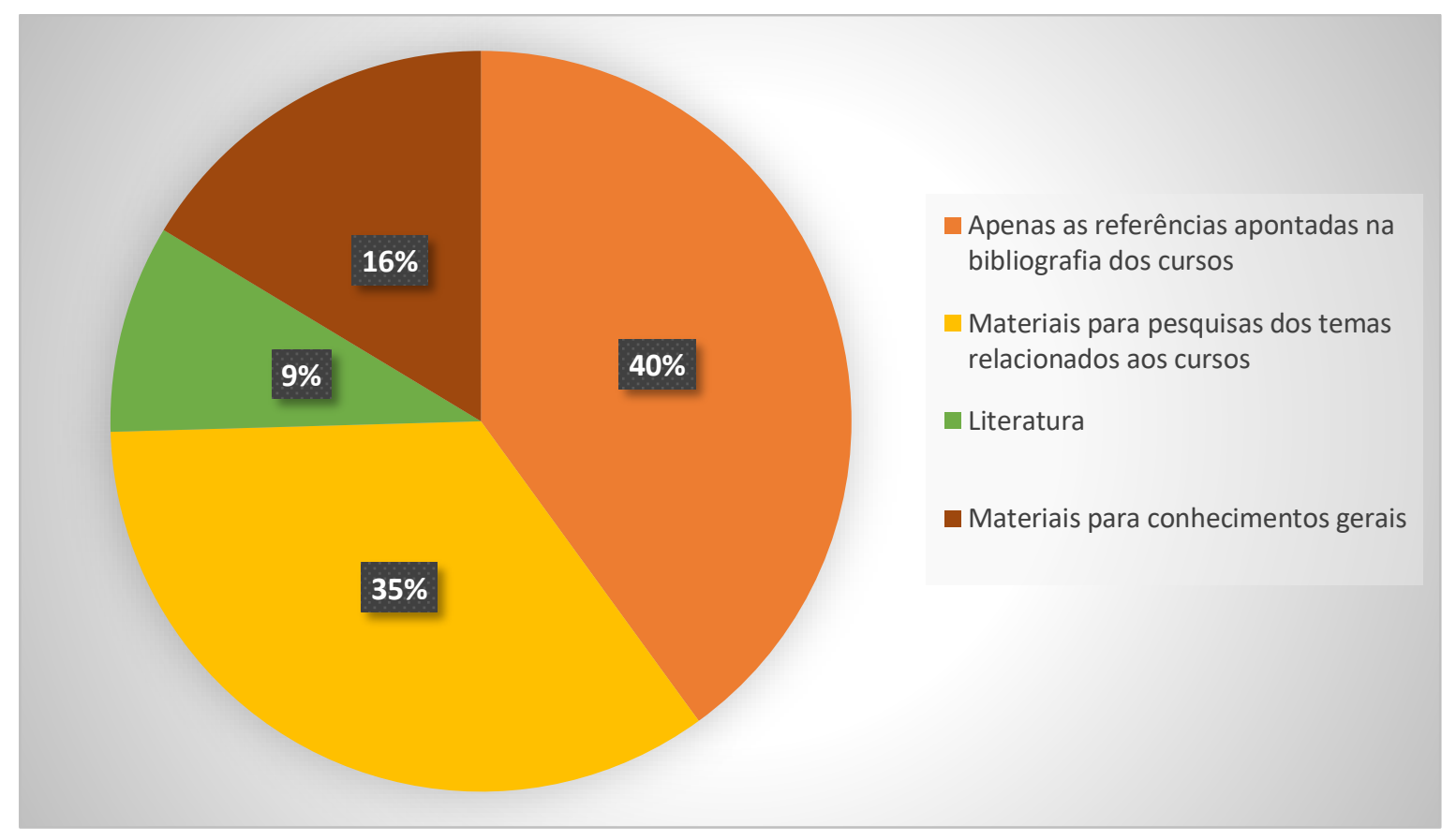

Fonte: Elabora pela autora

Distribuindo os dados do Gráfico 12 entre as categorias, o Gráfico 13 mostra: 
Gráfico 13 - Tipo de material procurado dividido por categorias de usuários

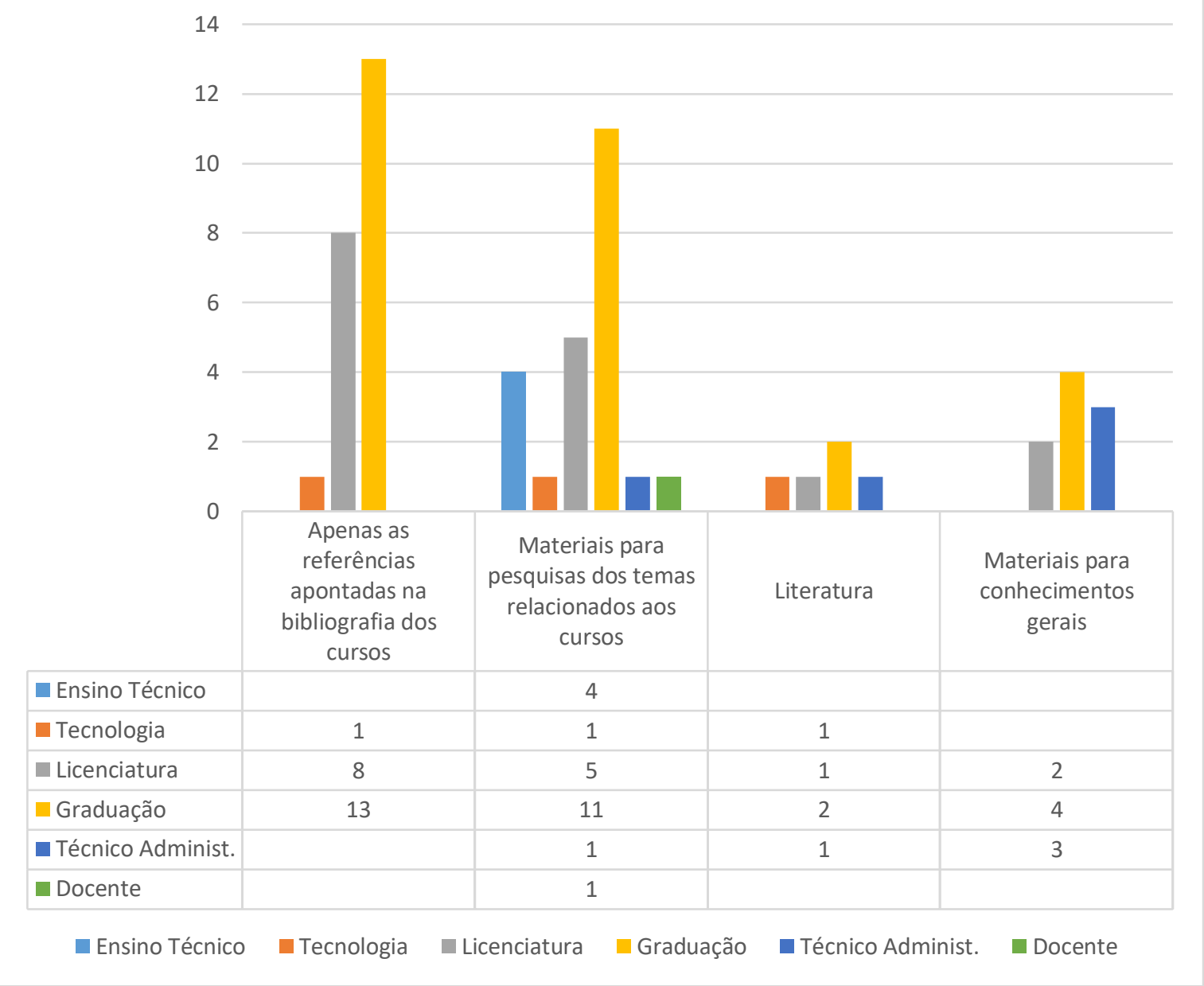

Fonte: Elabora pela autora

A opção "Materiais para pesquisa dos temas relacionados aos cursos" foi apontada com unanimidade pelo ensino técnico e escolhida por um dos técnicos administrativos estudantes do mestrado e pelo docente.

A opção "Materiais para conhecimentos gerais" também recebeu apontamentos expressivos pelos representantes de cursos de graduação e licenciatura e pelos técnicos administrativos.

Ao se examinar o Relatório de Títulos Mais Emprestados desde a implementação do sistema Pergamum na biblioteca do campus São Paulo, entre 25 de julho de 2017 e 29 de maio de 2018, verifica-se que, dos 100 títulos mais emprestados, são maioria as literaturas não indicadas nos Programas Pedagógicos de Cursos, que desbancaram os títulos exibidos nos PPCs. 
Na Tabela 5, listamos os títulos mais emprestados e a quantidade de empréstimos:

Tabela 5 - Títulos mais emprestados

\begin{tabular}{|c|c|c|}
\hline Posição & Título & $\begin{array}{l}\mathbf{N}^{\circ} \text { de } \\
\text { empréstimo }\end{array}$ \\
\hline $61^{\circ}$. & $\begin{array}{l}\text { BRADBURY, Ray. Fahrenheit 451. 2. ed. São Paulo: Biblioteca } \\
\text { Azul, Editora Globo, 2012. } 215 \text { p. ISBN } 9788525052247\end{array}$ & 56 \\
\hline $70^{\circ}$. & $\begin{array}{l}\text { GAARDER, Jostein. O mundo de Sofia: romance da história da } \\
\text { filosofia. São Paulo: Companhia das Letras, 2012. } 566 \text { p. ISBN } \\
9788535921892 .\end{array}$ & 47 \\
\hline $78^{\circ}$. & $\begin{array}{l}\text { ASSIS, Machado de. Memórias póstumas de Brás Cubas. 5. ed. } \\
\text { Rio de Janeiro: Record, } 2001 .\end{array}$ & 38 \\
\hline $80^{\circ}$. & $\begin{array}{l}\text { ROWLING, J. K. Harry Potter e a pedra filosofal. Rio de Janeiro: } \\
\text { Rocco, 2000. } 263 \text { p. ISBN } 8532511015 .\end{array}$ & 36 \\
\hline $87^{\circ}$ & $\begin{array}{l}\text { AZEVEDO, Aluísio. O cortiço. 2. ed. São Paulo: Saraiva, } 2009 . \\
246 \text { p. (Clássicos Saraiva). ISBN } 9788502072893 .\end{array}$ & 29 \\
\hline $90^{\circ}$. & $\begin{array}{l}\text { ANDRADE, Carlos Drummond de. Claro enigma. São Paulo: } \\
\text { Companhia das Letras, } 2012.134 \text { p. ISBN } 9788535920598 .\end{array}$ & 26 \\
\hline $91^{\circ}$. & $\begin{array}{l}\text { TAHAN, Malba. O homem que calculava. } 79 . \text { ed. Rio de Janeiro: } \\
\text { Record, 2010. } 300 \text { p. ISBN } 9788501061966 .\end{array}$ & 25 \\
\hline $92^{\circ}$. & $\begin{array}{l}\text { FRANK, Anne. O diário de Anne Frank. 54. ed. Rio de Janeiro: } \\
\text { Record, 2015. } 414 \text { p. ISBN } 9788501068200 .\end{array}$ & 24 \\
\hline $94^{\circ}$. & $\begin{array}{l}\text { KING, Stephen. O iluminado. 2. ed. Rio de Janeiro: Suma das } \\
\text { Letras, 2012. } 463 \text { p. ISBN } 9788581050485\end{array}$ & 22 \\
\hline $95^{\circ}$. & $\begin{array}{l}\text { ROWLING, J. K. Harry Potter e a câmara secreta. Rio de } \\
\text { Janeiro: Rocco, 2000. } 252 \text { p. ISBN 853251166X }\end{array}$ & 21 \\
\hline $95^{\circ}$. & $\begin{array}{l}\text { CLARKE, Arthur C. 2001: uma odisseia no espaço. São Paulo: } \\
\text { Aleph, 2013. } 330 \text { p. ISBN 9788576571551. }\end{array}$ & 21 \\
\hline $95^{\circ}$. & $\begin{array}{l}\text { MORLEY, Helena. Minha vida de menina. São Paulo: Companhia } \\
\text { de Bolso, 2016. } 325 \text { p. ISBN } 9788535927450 .\end{array}$ & 21 \\
\hline $96^{\circ}$. & $\begin{array}{l}\text { ALENCAR, José de. Senhora. 3. ed. São Paulo: Martin Claret, } \\
\text { 2001. } 244 \text { p. (A obra-prima de cada autor 73). ISBN } \\
9788572324823 .\end{array}$ & 20 \\
\hline $98^{\circ}$ & $\begin{array}{l}\text { ALENCAR, José de. Cinco minutos \& a viuvinha: texto integral. } \\
\text { 30. ed. São Paulo: Ática, 2011. } 135 \text { p. (Série Bom Livro). ISBN } \\
\text { 9788508145645. }\end{array}$ & 18 \\
\hline $99^{\circ}$. & $\begin{array}{l}\text { LEE, Harper; HORTA, Beatriz. O sol é para todos. 11. ed. Rio de } \\
\text { Janeiro: J. Olympio, 2015. } 349 \text { p. ISBN } 9788503009492 .\end{array}$ & 17 \\
\hline $99^{\circ}$. & $\begin{array}{l}\text { ROWELL, Rainbow. Eleanor \& Park. Barueri: Novo Século, } \\
\text { 2014. } 325 \text { p. ISBN } 9788542801255 .\end{array}$ & 17 \\
\hline $100^{\circ}$. & $\begin{array}{l}\text { AHERN, Cecelia. P. S. Eu te amo. Ribeirão Preto: Novo Conceito, } \\
\text { 2012. } 365 \text { ISBN } 9788581630625 .\end{array}$ & 16 \\
\hline $100^{\circ}$ & $\begin{array}{l}\text { CAMÕES, Luís de. Os lusíadas. São Paulo: Saraiva, 2010. } 319 \text { p. } \\
\text { (Clássicos Saraiva). ISBN } 9788502094901\end{array}$ & 16 \\
\hline
\end{tabular}

Fonte: Elabora pela autora baseado no sistema Pergamum 
É importante mencionar que a Tabela 5 contém vários títulos que configuram as listas de livros obrigatórios para a seleção de 2017 e 2018 dos vestibulares da USP e da Unicamp, incluindo títulos que não foram listados por integrar os PPCs.

Embora a Biblioteca faça a aquisição por compra de livros literários com foco no ensino técnico e público externo, foram as outras categorias que responderam utilizar os livros de literatura. Esse tema pode ser controverso, principalmente enquanto a tipologia das bibliotecas dos IFs não estiver bem estabelecida. Precisaremos de outros estudos para nos aprofundarmos nessa questão específica e entendermos o quanto a disponibilização de literatura interfere no oferecimento de outros produtos e/ou atrasa outras demandas. 
Questão 8: “Em geral, você encontra na Biblioteca o que procura?”. O intuito da pergunta foi medir o uso do acervo.

Os resultados demonstraram que a opção “Às vezes” foi a mais selecionada em todas as categorias, muito embora a opção "Muitas vezes" tenha recebido quase o mesmo número de escolhas. A opção "Sempre” foi escolhida em menor número. Encontrar livros foi apontado por dois alunos da graduação e um da licenciatura.

Alguns alunos expressaram na resposta "Outros" que não conhecem as referências das ementas do PPC dos cursos que integram. Isso fica claro na declaração de um aluno da graduação: "Não sei avaliar. Nunca busquei o livro indicado na disciplina".

Também na opção "Outros", um discente da licenciatura escreveu: "Encontro muitas vezes, mas sinto falta de autores negros, como Carolina Maria de Jesus”. Esse apontamento vai ao encontro das sugestões bibliográficas feitas pelo Núcleo de Estudos Afro-brasileiros e Indígenas (Neabi). O Neabi ${ }^{18}$, instituído por Decreto em 8 de abril de 2013, tem por objetivo “contribuir com referências para a prática pedagógica docente no que tange à promoção da diversidade étnico-racial". De acordo com a política de coleções praticada, a Biblioteca encaminhou a lista para a aquisição por compra.

\footnotetext{
${ }^{18}$ http://www2.ifsp.edu.br/index.php/instituicao/nucleos/neabi.html
} 
Gráfico 14 - Localização de material

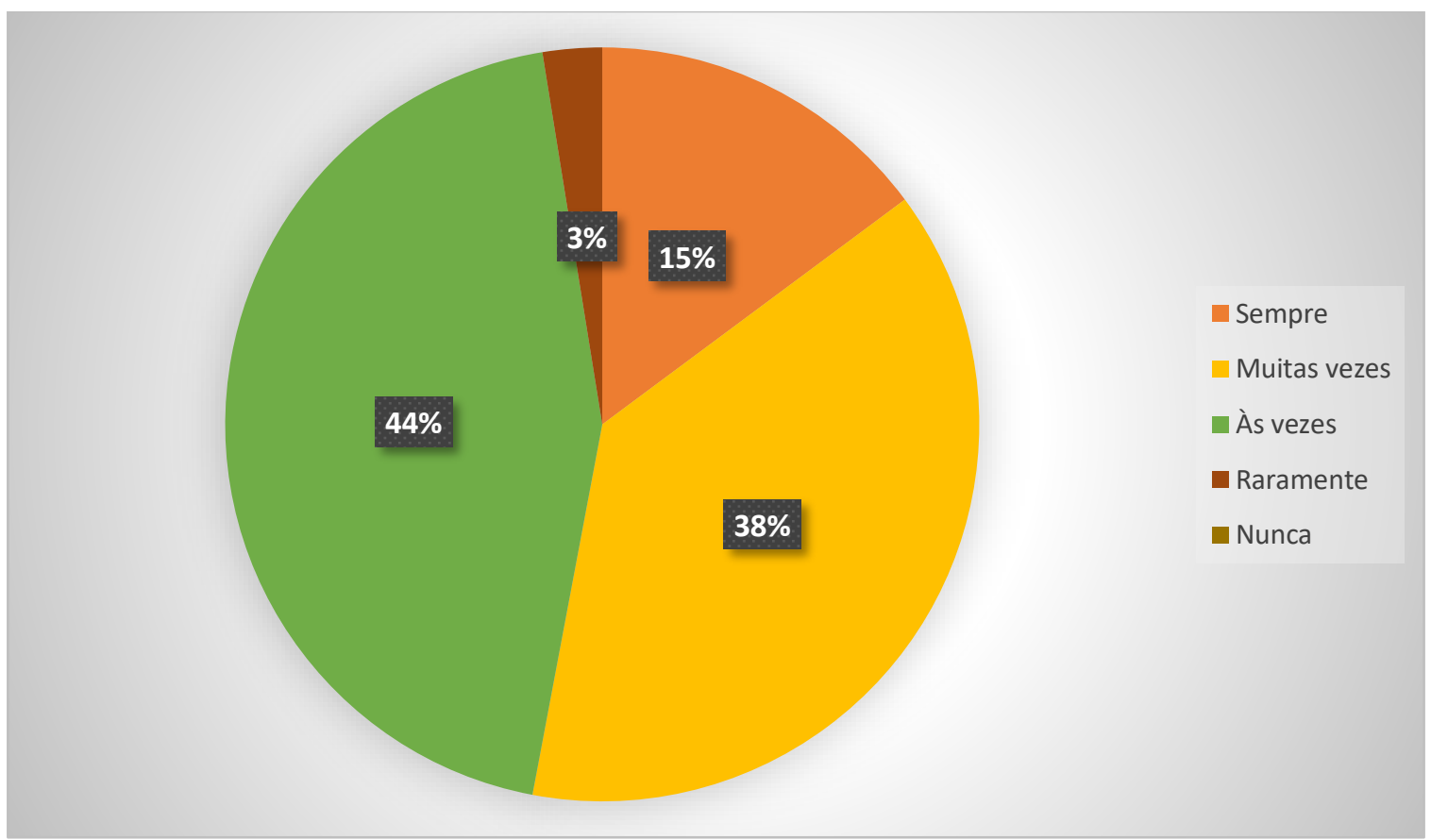

Fonte: Elabora pela autora

Distribuindo os dados do Gráfico 14 entre as categorias, o Gráfico 15 mostra:

Gráfico 15 - Localização de material dividido por categorias de usuários

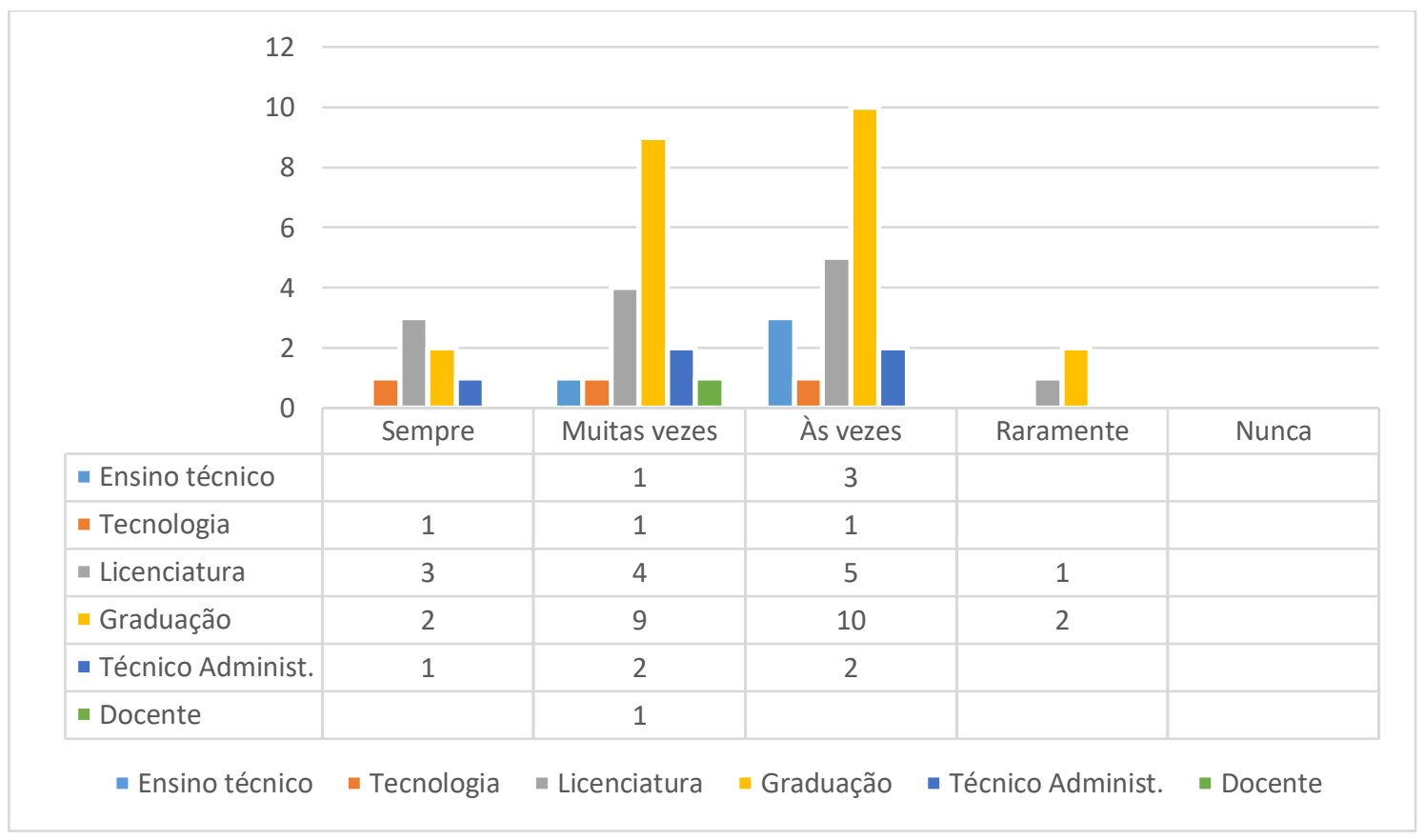

Fonte: Elabora pela autora 
Questão 9: "Especificamente sobre os livros indicados na bibliografia de seu curso, você encontra as indicações na Biblioteca?’. O propósito era avaliar o uso do acervo. As três primeiras opções - Sempre, Muitas vezes e Ás vezes - mostram a mesma porcentagem de escolhas pelos 47 respondentes. Assim, concluímos que não há muita dificuldade em se encontrar as literaturas indicadas.

Entretanto, algumas considerações precisam ser realizadas quanto ao conhecimento dos alunos sobre as indicações bibliográficas. Como dito anteriormente, é possível que, em alguns cursos, os alunos, incluindo os participantes do questionário, não tenham ciência das referências das ementas dos PPCs dos cursos que integram. Outros apontamentos de alunos da graduação: “Poucas vezes. Do meu curso, faltam, inclusive, livros indicados na bibliografia básica"; "Até o momento sim, mas são poucos exemplares”.

As respostas nos conduzem a acreditar que as bibliografias reconhecidas das ementas dos PPCs têm sido atendidas. O fato da opção "Raramente" ser apontada por poucos alunos ratifica essa crença. Sobre a verificação de quantidades, falaremos em questão própria que avalia esse quesito.

Três servidores estudantes do mestrado, sendo um deles discente do campus São Paulo, responderam a essa questão. Dois deles selecionaram a resposta "Às vezes". O terceiro se identificou e declarou o que consideramos como "às vezes", afirmando: "Curso Mestrado em Educação em outra IES, cerca de 50\% das vezes tinha a obra procurada”. Interessante constatar que o acervo tem auxiliado estudantes externos, mesmo não sendo este seu objetivo principal. O fato do servidor cursar mestrado na área da Educação coincide com parte do acervo ligado aos cursos de licenciatura e mestrados. 
Gráfico 16 - Localização de livros indicados na bibliografia

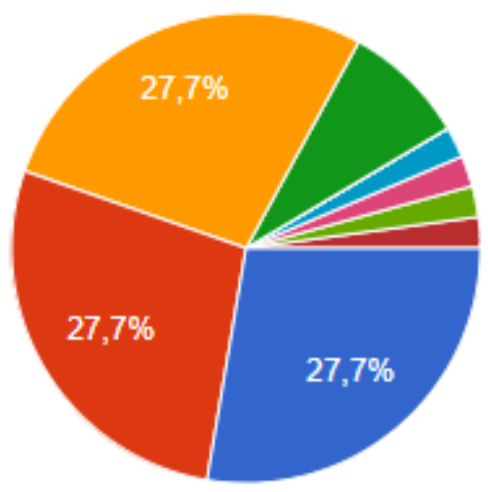

\section{Sempre}

Muitas vezes

Às vezes

Raramente

Nunca

Curso Mestrado em Educação em outra IES, cerca de $50 \%$ das vezes...

Até o momento sim, mas são pouco.

Não sei avaliar. Nunca busquei o liv..

Poucas vezes, do meu curso faltam...

Fonte: Formulário Google

Distribuindo os dados do Gráfico 16 entre as categorias, a Tabela 6 mostra:

Tabela 6 - Localização de livros indicados na bibliografia

\begin{tabular}{|c|c|c|c|c|c|c|}
\hline & $\begin{array}{c}\text { Ensino } \\
\text { Técnico }\end{array}$ & Tecnologia & Licenciatura & Graduação & $\begin{array}{c}\text { Técnico } \\
\text { Administrativo }\end{array}$ & Docente \\
\hline \multirow{6}{*}{$\begin{array}{r}\text { Sempre } \\
\text { Muitas } \\
\text { vezes } \\
\text { Às vezes } \\
\text { Raramente } \\
\text { Nunca }\end{array}$} & 2 & 2 & 3 & 6 & & \\
\hline & 1 & & 5 & 6 & & 1 \\
\hline & & & 4 & 7 & 2 & \\
\hline & 1 & 1 & 1 & 1 & & \\
\hline & & & & & & \\
\hline & & & & $\begin{array}{l}\text { Poucas vezes, do } \\
\text { meu curso faltam, } \\
\text { inclusive, livros } \\
\text { indicados na } \\
\text { bibliografia } \\
\text { básica } \\
\text { Não sei avaliar. } \\
\text { Nunca busquei o } \\
\text { livro indicado na } \\
\text { disciplina. } \\
\text { Até o momento } \\
\text { sim, mas são } \\
\text { poucos } \\
\text { exemplares }\end{array}$ & $\begin{array}{c}\text { Curso Mestrado } \\
\text { em Educação } \\
\text { em outra IES, } \\
\text { cerca de } 50 \% \\
\text { das vezes tinha } \\
\text { a obra } \\
\text { procurada. }\end{array}$ & \\
\hline
\end{tabular}

Fonte: Elabora pela autora 
Questão 10: "Quando a Biblioteca não tem o material bibliográfico indicado nos cursos, você...”. A intenção foi analisar o comportamento dos usuários quando não encontram o material que procuram na biblioteca do campus São Paulo.

Com 48 respostas, a opção mais selecionada foi "Procura o material na versão digital na internet”. A opção foi indicada por todas as categorias, o que demonstra que, quando os usuários não localizam os materiais bibliográficos disponíveis para empréstimos na Biblioteca, recorrem à internet. Por outro lado, a opção "Empresta dos amigos" foi a menos selecionada. Os alunos do ensino técnico somente recorrem à internet; os da graduação até utilizam outros meios, mas todos foram unanimes na escolha da internet como opção. É possível que a atitude nos diga que eles utilizam a internet em busca de resultados mais rápidos, afinal, consultar terceiros pode ser mais demorado. Os usuários de bibliotecas universitárias, cada vez mais, utilizam-se dos meios digitais para facilitar seus estudos. Podemos afirmar que o comportamento dos usuários de hoje é diferente do comportamento dos usuários de décadas passadas.

A segunda opção mais escolhida foi "Empresta de outras bibliotecas", sendo que os servidores são os maiores utilizadores dessa prática. O item "compra o material indicado" foi o menos assinalado entre os alunos dos cursos superiores. 
Gráfico 17 - Comportamento do usuário

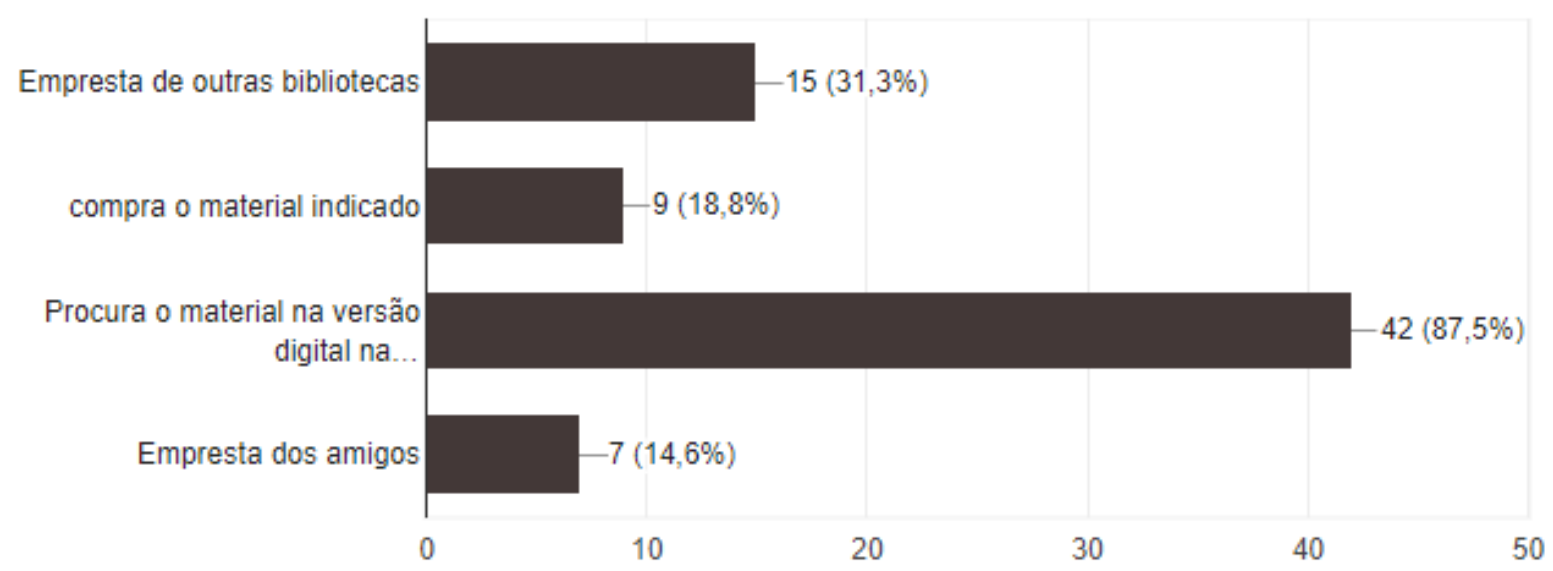

Fonte: Formulário Google

Distribuindo os dados do Gráfico 17 entre as categorias, a Tabela 7 mostra:

Tabela 7 - Comportamento do usuário

Ensino Tecnologia Licenciatura Graduação Técnico Docente

Técnico Adminst.

\begin{tabular}{|c|c|c|c|c|c|c|}
\hline \multirow{5}{*}{$\begin{array}{r}\text { Empresta de outras bibliotecas } \\
\text { Compra o material indicado } \\
\text { Procura o material na versão } \\
\text { digital na Internet } \\
\text { Empresta dos amigos } \\
\text { Outro }\end{array}$} & & & 4 & 7 & 3 & 1 \\
\hline & & 1 & 1 & 4 & 2 & 1 \\
\hline & 4 & 3 & 11 & 23 & 1 & \\
\hline & & & 3 & 3 & 1 & \\
\hline & & & & & & \\
\hline
\end{tabular}

Fonte: Elabora pela autora 
Questão 11: "Dos materiais da Biblioteca, qual a sua preferência entre as versões?". Foram 49 respostas entre as duas opções disponíveis. Foi interessante perceber que, muito embora, na questão 10, os usuários tenham respondido quase que em sua maioria que procuram o material na versão digital na internet, nesta questão, indicaram, de forma unânime, a opção "Empréstimo do livro impresso", tanto os alunos do ensino técnico e da licenciatura quanto os servidores técnico-administrativos. A opção foi selecionada em menor número por alunos da graduação, dos curso de tecnologia e docentes.

Gráfico 18 - Preferência de materiais

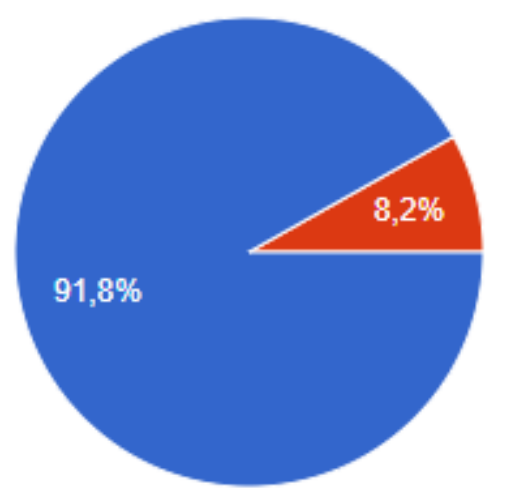

empréstimo do livro impresso

versão do livro digital

Fonte: Formulário Google

Distribuindo os dados do Gráfico 18 entre as categorias, a Tabela 8 mostra:

Tabela 8 - Preferência de materiais dividida por categorias de usuários

\begin{tabular}{r|c|c|c|c|c|c|}
\multicolumn{2}{c}{$\begin{array}{c}\text { Ensino } \\
\text { Técnico }\end{array}$} & Tecnologia & \multicolumn{2}{c}{ Licenciatura } & Graduação & \multicolumn{1}{c}{ Técnico } \\
Administ. & Docente \\
\hline Empréstimo do livro impresso & 4 & 2 & 13 & 21 & 5 & \\
\cline { 2 - 8 } Versão do livro digital & & 1 & & 2 & & 1 \\
\cline { 2 - 8 }
\end{tabular}

Fonte: Elabora pela autora 
O bloco seguinte de questões concentra-se nos seguintes serviços: empréstimo de livros, livros digitais da Person, empréstimo de revistas, Portal de Revistas Científicas online do IFSP, Portal de Periódicos Capes, Pergamum - Catálogo online do IFSP, e Normas ABNT e ISO assinadas pelo IFSP, analisando o uso de serviços relacionados ao acervo.

Questão 12: “Quais serviços da Biblioteca você utiliza? - Empréstimo de livros”. Das 49 respostas, depreende-se que, em geral, os alunos participantes do questionário conhecem e utilizam de vez em quando o serviço de empréstimo. Existe um número expressivo de estudantes da licenciatura e da graduação que conhecem e utilizam com frequência o serviço. Por outro lado, alunos da graduação responderam conhecê-lo e não utilizá-lo.

Gráfico 19 - Empréstimo de livros

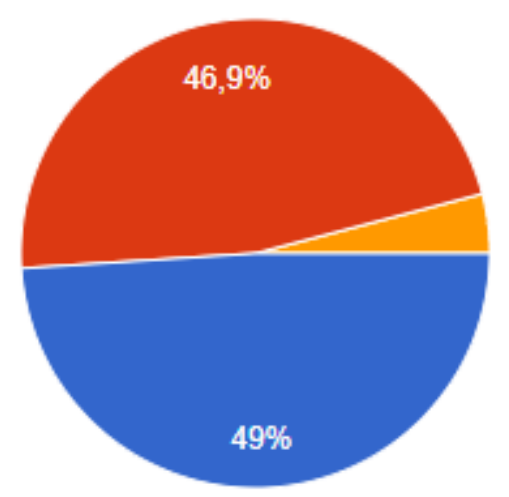

Conheço e utilizo com frequência

Conheço e utilizo de vez em quando

Conheço e não utilizo

Não conheço

Fonte: Formulário Google

Distribuindo os dados do Gráfico 19 entre as categorias, a Tabela 9 mostra:

Tabela 9 - Empréstimo de livros

\begin{tabular}{rl|c|c|c|c|c|c|}
\multicolumn{2}{c}{$\begin{array}{c}\text { Ensino } \\
\text { Técnico }\end{array}$} & Tecnologia & Licenciatura & Graduação & \multicolumn{1}{c}{$\begin{array}{c}\text { Técnico } \\
\text { Administ. }\end{array}$} \\
\hline $\begin{array}{r}\text { Conheço e utilizo com frequência } \\
\text { Conheço e utilizo de vez em quando } \\
\text { Conheço e não utilizo } \\
\text { Não conheço }\end{array}$ & & 1 & 11 & 9 & 3 & \\
\cline { 2 - 8 } & & 2 & 3 & 11 & 2 & 1 \\
\cline { 2 - 8 } & & & & 2 & & \\
\hline
\end{tabular}


Questão 13: "Quais serviços da Biblioteca você utiliza? - Livros digitais da Person assinados pelo IFSP”. A totalidade dos alunos do ensino técnico declarou não conhecer o serviço. As outras categorias de curso tiveram números altos da mesma resposta e da opção “Conheço e não utilizo". Somente $8,2 \%$ de alunos dos cursos superiores de graduação e licenciatura dizem conhecer e utilizar com frequência ou utilizar de vez em quando esse serviço. O representante docente diz utilizá-lo com frequência e parte dos outros servidores, de vez em quando.

Gráfico 20 - Livros digitais da Person

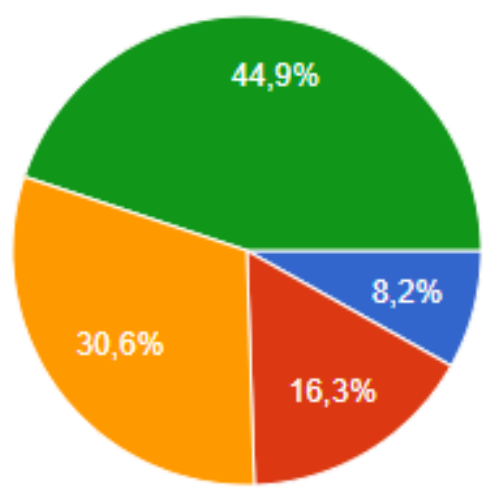

Conheço e utilizo com frequência

Conheço e utilizo de vez em quando

Conheço e não utilizo

Não conheço

Fonte: Formulário Google

Distribuindo os dados do gráfico 20 entre as categorias, a tabela 10 mostra:

Tabela 10 - Livros digitais da Person

\begin{tabular}{|c|c|c|c|c|c|c|}
\hline & $\begin{array}{c}\text { Ensino } \\
\text { Técnico }\end{array}$ & Tecnologia & Licenciatura & Graduação & $\begin{array}{c}\text { Técnico } \\
\text { Administ. }\end{array}$ & Docente \\
\hline \multirow{4}{*}{$\begin{array}{r}\text { Conheço e utilizo com frequência } \\
\text { Conheço e utilizo de vez em quando } \\
\text { Conheço e não utilizo } \\
\text { Não conheço }\end{array}$} & & & 1 & 2 & & 1 \\
\hline & & & 2 & 4 & 2 & \\
\hline & & 1 & 5 & 8 & 1 & \\
\hline & 4 & 2 & 4 & 10 & 2 & \\
\hline
\end{tabular}

Fonte: Elabora pela autora 
Questão 14: "Quais serviços da Biblioteca você utiliza? - Empréstimo de revistas”. Das 49 respostas, 53,1\% dos usuários conhecem, mas não utilizam o serviço de empréstimo de revistas impressas. Os usuários que mais utilizam esse serviço são os técnicos administrativos. Poucos alunos da licenciatura o utilizam.

Gráfico 21 - Empréstimo de revistas

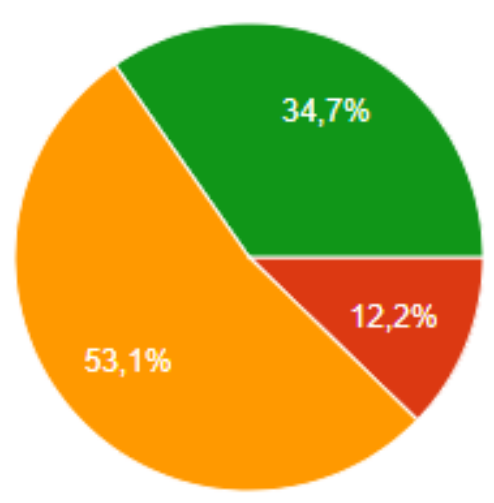

Conheço e utilizo com frequência

Conheço e utilizo de vez em quando

Conheço e não utilizo

Não conheço

Fonte: Formulário Google

Distribuindo os dados do Gráfico 21 entre as categorias, a tabela 11 mostra:

Tabela 11 - Empréstimo de revistas

\begin{tabular}{|c|c|c|c|c|c|c|}
\hline & $\begin{array}{c}\text { Ensino } \\
\text { Técnico }\end{array}$ & Tecnologia & Licenciatura & Graduação & $\begin{array}{c}\text { Técnico } \\
\text { Administ. }\end{array}$ & Docente \\
\hline \multirow{4}{*}{$\begin{array}{r}\text { Conheço e utilizo com frequência } \\
\text { Conheço e utilizo de vez em quando } \\
\text { Conheço e não utilizo } \\
\text { Não conheço }\end{array}$} & & & & & & \\
\hline & & & 2 & & 4 & \\
\hline & 2 & 1 & 6 & 15 & 1 & 1 \\
\hline & 2 & 2 & 5 & 8 & & \\
\hline
\end{tabular}

Fonte: Elabora pela autora 
Questão 15: “Quais serviços da Biblioteca você utiliza? - Portal de Revistas

Científicas online do IFSP”. 67,3\% dos usuários diz não conhecer o Portal de Revistas do IFSP e 20,4\% declaram conhecer e não utilizar. $12,2 \%$ declararam conhecer e utilizar de vez em quando.

Gráfico 22 - Portal de Revistas Científicas online do Instituto Federal São Paulo

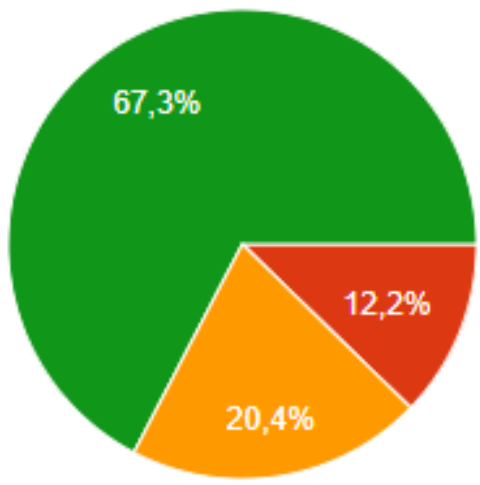

Conheço e utilizo com frequência

Conheço e utilizo de vez em quando

Conheço e não utilizo

Não conheço

Fonte: Formulário Google

Distribuindo os dados do Gráfico 22 em categorias, a tabela 12 mostra:

Tabela 12 - Portal de Revistas Científicas online do Instituto Federal São Paulo

\begin{tabular}{|c|c|c|c|c|c|c|}
\hline & $\begin{array}{c}\text { Ensino } \\
\text { Técnico }\end{array}$ & Tecnologia & Licenciatura & Graduação & $\begin{array}{c}\text { Técnico } \\
\text { Administ. }\end{array}$ & Docente \\
\hline \multirow{4}{*}{$\begin{array}{r}\text { Conheço e utilizo com frequência } \\
\text { Conheço e utilizo de vez em quando } \\
\text { Conheço e não utilizo } \\
\text { Não conheço }\end{array}$} & & & & & & \\
\hline & & 1 & 1 & 3 & 1 & \\
\hline & 1 & & 3 & 3 & 3 & \\
\hline & 3 & 2 & 9 & 17 & 1 & 1 \\
\hline
\end{tabular}

Fonte: Elabora pela autora 
Questão 16: "Quais serviços da Biblioteca você utiliza? - Portal de Periódicos Capes”. Número expressivo de estudantes de todas as categorias julga desconhecer o serviço, diferentemente dos servidores, que declaram conhecê-lo. O número expressa que os estudantes de mestrado se alinham a parte dos objetivos institucionais da Capes. Outra parte dos objetivos da Capes relaciona-se ao Decreto $n^{\circ} 6.755$, de 29 de janeiro de 2009, que institui a Política Nacional de Formação de Profissionais do Magistério da Educação Básica. Isso, talvez, indique o porquê de alguns discentes da licenciatura conhecer e utilizar com frequência ou de vez em quando o serviço.

\section{Gráfico 23 - Portal de Periódicos Capes}

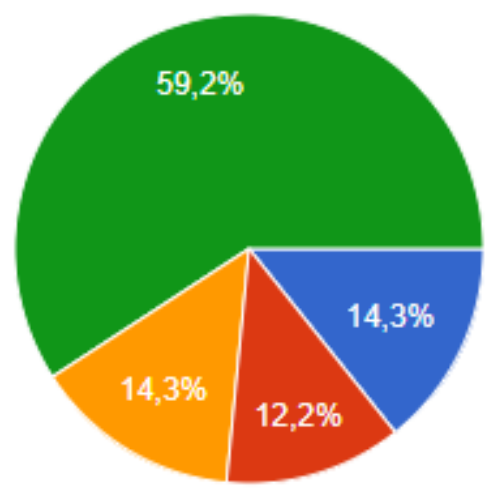

Conheço e utilizo com frequência

Conheço e utilizo de vez em quando

Conheço e não utilizo

Não conheço

Fonte: Formulário Google

Distribuindo os dados do Gráfico 23, em categorias, a Tabela 13 monstra:

Tabela 13 - Portal de Periódicos Capes

\begin{tabular}{|c|c|c|c|c|c|c|}
\hline & $\begin{array}{c}\text { Ensino } \\
\text { Técnico }\end{array}$ & Tecnologia & Licenciatura & Graduação & $\begin{array}{c}\text { Técnico } \\
\text { Administ. }\end{array}$ & Docente \\
\hline \multirow{4}{*}{$\begin{array}{r}\text { Conheço e utilizo com frequência } \\
\text { Conheço e utilizo de vez em quando } \\
\text { Conheço e não utilizo } \\
\text { Não conheço }\end{array}$} & & & 2 & 2 & 2 & 1 \\
\hline & & 1 & 2 & 2 & 1 & \\
\hline & & & 1 & 4 & 2 & \\
\hline & 4 & 2 & 8 & 15 & & \\
\hline
\end{tabular}

Fonte: Elabora pela autora 
Questão 17: “Quais serviços da Biblioteca você utiliza? - Pergamum (Catálogo online do IFSP)". Os números indicam que a maior parte da comunidade acadêmica utiliza o catálogo da Biblioteca, mas, ainda assim, alguns alunos de todos as categorias declaram desconhecer o serviço.

Gráfico 24 - Pergamum - Catálogo online do IFSP

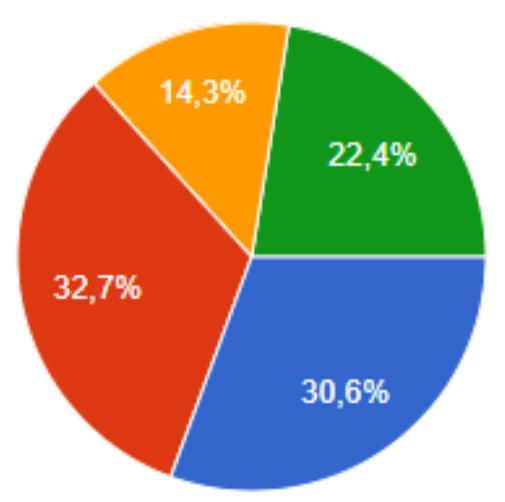

Conheço e utilizo com frequência

Conheço e utilizo de vez em quando

Conheço e não utilizo

Não conheço

Fonte: Formulário Google

Distribuindo os dados do Gráfico 24 em categorias, a Tabela 14 mostra:

Tabela 14 - Pergamum - Catálogo online do IFSP

\begin{tabular}{|c|c|c|c|c|c|c|}
\hline & $\begin{array}{l}\text { Ensino } \\
\text { Técnico }\end{array}$ & Tecnologia & Licenciatura & Graduação & $\begin{array}{c}\text { Técnico } \\
\text { Administ. }\end{array}$ & Docente \\
\hline \multirow{4}{*}{$\begin{array}{r}\text { Conheço e utilizo com frequência } \\
\text { Conheço e utilizo de vez em quando } \\
\text { Conheço e não utilizo } \\
\text { Não conheço }\end{array}$} & 1 & 1 & 4 & 6 & 2 & 1 \\
\hline & 1 & & 4 & 8 & 3 & \\
\hline & & & 2 & 6 & & \\
\hline & 2 & 2 & 3 & 3 & & \\
\hline
\end{tabular}

Fonte: Elabora pela autora 
Questão 18: “Quais serviços da Biblioteca você utiliza? - Normas ABNT e ISO assinadas pelo IFSP". A maior parte dos alunos declarou desconhecer a assinatura das normas. Número expressivo indicou conhecer e não utilizar.

Gráfico 25 - Normas ABNT e ISO

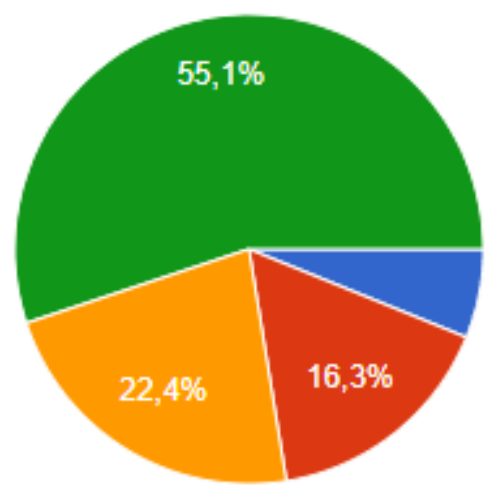

Conheço e utilizo com frequência

Conheço e utilizo de vez em quando

Conheço e não utilizo

Não conheço

Fonte: Formulário Google

Distribuindo os dados do Gráfico 25, em categorias, a tabela 15 mostra:

Tabela 15 - Normas ABNT e ISO

\begin{tabular}{|c|c|c|c|c|c|c|}
\hline & $\begin{array}{l}\text { Ensino } \\
\text { Técnico }\end{array}$ & Tecnologia & Licenciatura & Graduação & $\begin{array}{c}\text { Técnico } \\
\text { Administ. }\end{array}$ & Docente \\
\hline \multirow{4}{*}{$\begin{array}{r}\text { Conheço e utilizo com frequência } \\
\text { Conheço e utilizo de vez em quando } \\
\text { Conheço e não utilizo } \\
\text { Não conheço }\end{array}$} & & 1 & & & 2 & \\
\hline & & & 2 & 4 & 1 & 1 \\
\hline & 1 & & 4 & 5 & 1 & \\
\hline & 3 & 2 & 7 & 14 & 1 & \\
\hline
\end{tabular}

Fonte: Elabora pela autora 
Questão 19: “Como você avalia a coleção de livros e os serviços voltados ao acervo? Qualidade dos títulos disponíveis”. A intenção foi avaliar o acervo a partir da visão da comunidade acadêmica. A maior parte dos alunos de todas as categorias e os servidores técnicoadministrativos consideram boa a qualidade dos títulos disponíveis. Entretanto, é bem expressivo o número de alunos que a consideram regular, assim como o docente participante da pesquisa.

Gráfico 26 - Qualidade dos títulos disponíveis

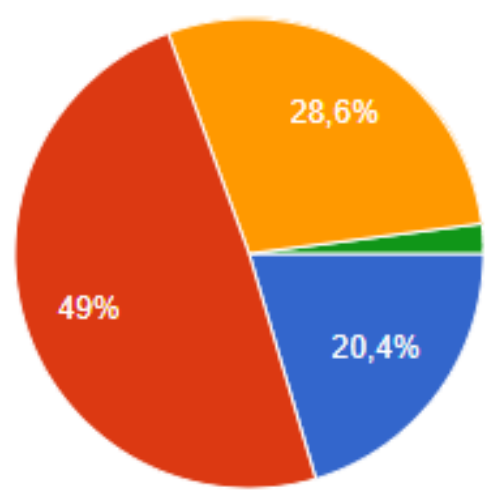
Excelente
Bom
Regular
Ruim

Fonte: Formulário Google

Distribuindo os dados do Gráfico 26 em categorias, a Tabela 16 mostra:

Tabela 16 - Qualidade dos títulos disponíveis dividida por categoria de usuários

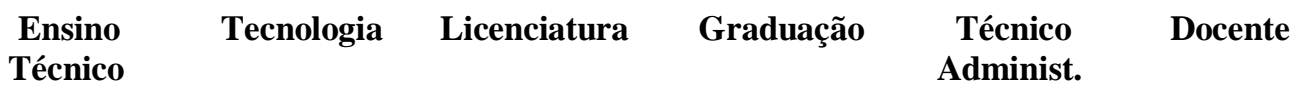

\begin{tabular}{|r|c|c|c|c|c|c|} 
Excelente & 1 & 1 & 2 & 4 & 2 & \\
\cline { 2 - 7 } Bom & 3 & 1 & 7 & 10 & 3 & \\
\cline { 2 - 7 } Regular & & & 4 & 9 & & 1 \\
\cline { 2 - 7 } & & 1 & & & & \\
\cline { 2 - 7 } & & &
\end{tabular}

Fonte: Elabora pela autora 
Questão 20: “Como você avalia a coleção de livros e os serviços voltados ao acervo? Estado de conservação dos exemplares". A intenção foi avaliar o acervo a partir da visão da comunidade acadêmica. Da mesma forma que na questão anterior, a maior parte dos alunos de todas as categorias considera bom o estado de conservação dos exemplares, assim como os servidores técnico-administrativos e o docente. O número de alunos que consideram o serviço como excelente é maior do que o número de alunos que o consideram regular ou ruim.

Gráfico 27 - Estado de conservação dos exemplares

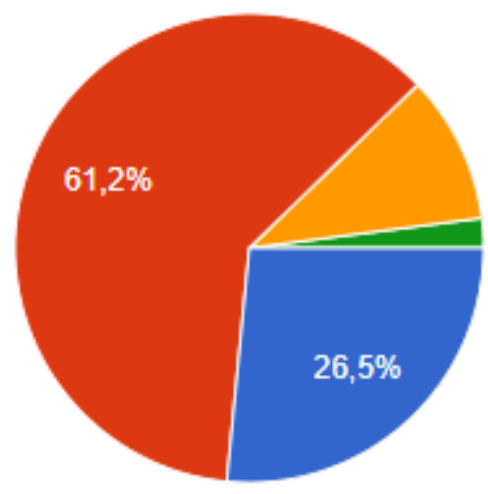

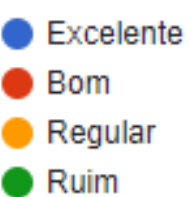

Fonte: Formulário Google

Distribuindo os dados do Gráfico 27 em categorias, a Tabela 17 mostra:

Tabela 17 - Estado de conservação dos exemplares dividido por categorias

\begin{tabular}{|c|c|c|c|c|c|c|}
\hline & $\begin{array}{l}\text { Ensino } \\
\text { Técnico }\end{array}$ & Tecnologia & Licenciatura & Graduação & $\begin{array}{c}\text { Técnico } \\
\text { Administ. }\end{array}$ & Docente \\
\hline \multirow{4}{*}{$\begin{array}{r}\text { Excelente } \\
\text { Bom } \\
\text { Regular } \\
\text { Ruim }\end{array}$} & 1 & 1 & 4 & 6 & 1 & \\
\hline & 2 & 2 & 7 & 15 & 3 & 1 \\
\hline & 1 & & 1 & 2 & 1 & \\
\hline & & & & 1 & & \\
\hline
\end{tabular}

Fonte: Elabora pela autora 
Questão 21: “Como você avalia a coleção de livros e os serviços voltados ao acervo? Quantidade de exemplares disponíveis”. A intenção foi avaliar o acervo a partir da visão da comunidade acadêmica. Nesse caso, a maior parte dos alunos de todas as categorias considera regular a quantidade de exemplares. O número de alunos que a consideram boa é maior do que o número de alunos que a consideram ruim ou excelente.

Gráfico 28 - Quantidade de exemplares

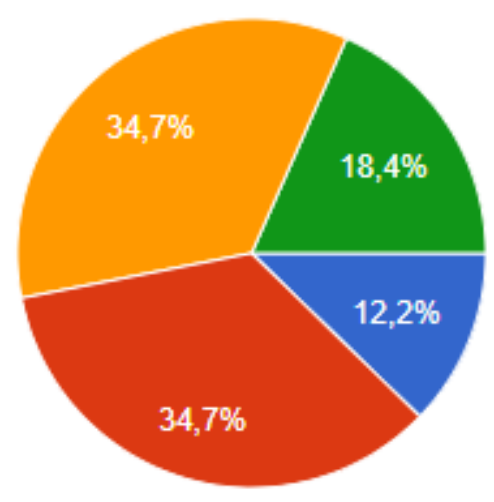

$$
\begin{aligned}
& \text { Excelente } \\
& \text { Bom } \\
& \text { Regular } \\
& \text { Ruim }
\end{aligned}
$$

\begin{tabular}{|c|c|c|c|c|c|c|}
\hline & $\begin{array}{l}\text { Ensino } \\
\text { Técnico }\end{array}$ & Tecnologia & Licenciatura & Graduação & $\begin{array}{l}\text { Técnico } \\
\text { Administ. }\end{array}$ & Docente \\
\hline \multirow{4}{*}{$\begin{array}{r}\text { Excelente } \\
\text { Bom } \\
\text { Regular } \\
\text { Ruim }\end{array}$} & & & 2 & 2 & 2 & \\
\hline & 2 & 2 & 5 & 5 & 1 & 1 \\
\hline & 1 & & 3 & 12 & 1 & \\
\hline & 1 & 1 & 3 & 3 & 1 & \\
\hline
\end{tabular}

Fonte: Formulário Google

Distribuindo os dados do Gráfico 28 em categorias, a Tabela 18 mostra:

Tabela 18 - Quantidade de exemplares

Fonte: Elabora pela autora 


\section{CONSIDERAÇÕES FINAIS}

Os Institutos Federais são considerados entidades inéditas por oferecerem educação básica, superior e profissional concentrada em Ciência e Tecnologia, garantindo um percentual mínimo de licenciaturas e educação profissional técnica de nível médio. Essas particularidades têm reflexo sobre as bibliotecas dessas instituições, que desenvolvem papel fundamental no auxílio do tripé ensino, pesquisa e extensão.

O objetivo desta pesquisa foi o de analisar a percepção dos usuários potenciais da Biblioteca Francisco Montojos do IFSP - Campus São Paulo a partir do desenvolvimento institucional de coleções e de serviços relacionados. Para isso, foi utilizada a análise documental e aplicação de questionários.

Dessa forma, ao se analisarem os princípios que regem o Plano de Desenvolvimento Institucional 2014-2018 do IFSP cotejado à missão da Biblioteca, um dos objetivos específicos deste trabalho, verifica-se que as antigas instituições que agregavam bibliotecas e se converteram a IF não oficializaram a existência dessas bibliotecas, ou seja, não existem documentos oficiais exclusivos sobre a constituição da Biblioteca Francisco Montojos, ou mesmo de outras bibliotecas na rede estadual e/ou federal dos IFs. Assim, comparamos o PDI com o objetivo estabelecido pela própria Biblioteca em 2008 e entendemos que, embora atenda aos tópicos expressos nos documentos institucionais, ele não expressa, hoje, a importância dessa biblioteca, ao se definir como suporte. Por isso, é necessário que os bibliotecários construam uma nova definição da missão institucional da Francisco Montojos, uma missão que melhor represente seu propósito na comunidade acadêmica.

Sobre o objetivo específico de examinar a Política de Desenvolvimento de Coleções das Bibliotecas do IFSP e sua compatibilidade com a missão e política institucional descrita no PDI, da análise documental, depreendemos que os documentos são consonantes no que tange a atrelar o desenvolvimento de coleções aos objetivos do IFSP. Essa prática ocorre, por exemplo, 
na aquisição por compra do acervo indicado na bibliografia apontada pelos Projetos Pedagógicos de Curso. Assim, percebemos que as projeções indicadas no Plano de Desenvolvimento foram cumpridas. Entretanto, tendo em vista que a projeção de aquisição por compra é determinada pelo PDI, o orçamento para compra deveria ser definido juntamente com as decisões de aquisição, para não ser necessário negociar quantias para o cumprimento das decisões estabelecidas anualmente na rede de forma desvinculada ao Conselho do Campus.

Especificamente sobre a Política de Desenvolvimento de Coleções das Bibliotecas do IFSP, constatou-se que o documento, quando descreve o processo de seleção e aquisição por compra, apresenta duas divergências que conflitam com as práticas exercidas no campus São Paulo:

1). O documento orienta os bibliotecários a conduzirem o processo de aquisição por compra. No campus São Paulo, essa orientação se choca com as especificidades de setores que participam de atividades ligadas à aquisição, pois os setores administrativos são autônomos e baseiam suas decisões nos órgãos consultivos e de assessoramento dos cursos, todos pautados em documentos oficiais. Assim, hoje, os profissionais da Biblioteca somente orientam e normalizam as especificidades referentes aos trabalhos da Biblioteca.

2) A política também diverge sobre os critérios de seleção: autoridade, atualidade do acervo, cobertura, precisão, imparcialidade, custo, idioma, relevância/interesse, durabilidade, acesso e suporte, que somente são aplicados na aquisição por compra de materiais bibliográficos indicados pela Biblioteca. No entanto, as indicações da Biblioteca são esporádicas e em menor volume. O maior volume do acervo é constituído, principalmente, pelas referências ligadas aos cursos, indicadas pelos PPCs, construídos nas áreas e em conjunto com o Núcleo Docente Estruturado com pouca - ou nenhuma - interferência da Biblioteca. A interferência ocorre ao apontar que bibliografias esgotadas/fora de catálogo precisam ser substituídas. Assim, percebemos que os critérios indicados na Política de Desenvolvimento de Coleções são válidos 
para compras indicadas pela Biblioteca, mas o principal critério utilizado para a seleção da maior parte dos materiais são os PPCs, que, juntamente aos instrumentos de avaliação/reconhecimento de cursos, normalizam títulos e quantidades para atender os 32 cursos do IFSP. Assim sendo, os apontamentos identificados neste estudo serão encaminhados à rede com a solicitação de revisão desses tópicos no documento referente ao campus São Paulo.

Quanto ao objetivo geral, relacionar a Política de Desenvolvimento de Coleções das Bibliotecas do IFSP à missão do Instituto, constatamos, com obviedade, que os documentos institucionais PDI e Relatório de Gestão e a Lei Federal n 11.892, de 29 de dezembro de 2008, se respaldam. Dessa forma, utilizamos os questionários para entender a percepção dos usuários sobre o acervo e os serviços oferecidos pela Biblioteca Francisco Montojos.

$\mathrm{Na}$ análise dos questionários, é importante ressaltar que a opção de não insistir de forma incisiva na participação dos públicos pode indicar o porquê de algumas categorias pouco terem participado da pesquisa. Para esses públicos (docentes, pós-graduandos e funcionários das empresas terceirizadas), será necessário um novo estudo - possivelmente, com abordagem diferente da que foi feita neste trabalho.

Dos demais participantes, os alunos da graduação foram os que mais se envolveram. Curiosamente, também nos chamou atenção a participação dos servidores técnicoadministrativos, que, em sua maioria, são discentes de cursos de mestrado em outras instituições. Assim, faz-se necessário um estudo de usuários para aprofundar o levantamento de demandas de todos esses públicos.

Sobre a utilização dos espaços da Biblioteca, estudantes dos cursos de licenciatura e graduação são o público mais frequente. Eles preferem estudar em grupo, com material próprio. É preciso destacar que, enquanto esta pesquisa foi realizada, o salão de estudos e o serviço de circulação tinham acesso por entradas diferentes e distantes entre si. A princípio, as entradas foram separadas devido à falta de espaço para os trabalhos com a troca de sistema da Biblioteca. 
Depois, as entradas continuaram separadas por causa da reforma da infraestrutura, que tem previsão de término em dezembro de 2018. Para atender os principais apontamentos dos contextos sugeridos para o uso do salão de estudos da Biblioteca, é necessário realizar remanejamento do mobiliário, de modo a viabilizar discussões em grupo, tornar a divisão dos espaços mais eficiente. É preciso adquirir mobiliário que caracterize a Biblioteca, também, como espaço de convivência, como um ambiente que sirva, até mesmo, para dormir, pois, por mais que dormir pareça uma necessidade frívola, para muitos alunos dos cursos integrais, a biblioteca também pode contribuir como espaço de relaxamento. Outro apontamento ligado ao salão de estudos, mas que tem afinidade direta com o serviço de referência, foi feito pelo técnico administrativo estudante de outra instituição, que, talvez, conheça serviço semelhante na instituição em que estuda, e esse pode ser um dos apontamentos mais simbólicos. Possivelmente, alunos não pedem por um serviço que não conhecem, e o fato de a Biblioteca ter precisado concentrar os esforços no acervo, por meio da alimentação da representação descritiva no novo sistema, relegou os serviços ao nível essencial. Isso demonstra que se faz urgente a necessidade de se reestruturar o serviço de referência.

No que diz respeito ao objetivo específico de identificar quais serviços oferecidos pela Biblioteca são percebidos pelos usuários como subsídio para sua necessidade de informação, dos serviços ligados ao acervo, percebemos que os alunos de graduação e licenciatura são os que mais declararam conhecer e utilizar os serviços de empréstimo, a biblioteca virtual da Person e o catálogo da Biblioteca. Por outro lado, a maior parte dos usuários de todas as categorias diz não conhecer o Portal de Revistas do IFSP, as Normas ABNT e o Portal de Periódicos Capes. No caso da portal da Capes, o questionário apresenta número expressivo de usuários que julgam desconhecer o serviço em todas as categorias de estudantes - com exceção dos servidores técnico-administrativos, que declaram conhecer o serviço. 
De qualquer forma, fica evidente que o serviço de referência precisa desenvolver divulgações e treinamentos para a comunidade acadêmica, diferentemente do serviço de assinatura de revistas impressas, que poucos conhecem, e os que conhecem não o utilizam. Neste caso, entendemos que é preciso direcionar o investimento empregado em outros produtos ou serviços mais atrativos.

Para os usuários, a finalidade de uso do acervo é direcionada ao suporte para trabalhos acadêmicos exigidos pelos cursos, e os materiais mais retirados são as referências apontadas na bibliografia dos cursos. Isso indica que os alunos se preocupam em fomentar seus estudos com materiais relativos aos cursos em detrimento de materiais para conhecimentos gerais e literatura. Por outro lado, verificando o Relatório de Títulos mais Emprestados desde a implementação do sistema Pergamum na Biblioteca Francisco Montjos, entre 25 de julho de 2017 a 29 de maio de 2018, dos 100 títulos mais emprestados, literaturas não indicadas em PPCs são destaque, desbancando títulos exigidos nos PPCs. Embora a Biblioteca faça a aquisição por compra de livros literários com foco no ensino técnico, foram estudantes do ensino superior que responderam utilizar os livros de literatura. Esse tema pode ser controverso, principalmente enquanto a tipologia das bibliotecas dos IFs não estiver bem estabelecida. Reiteramos que é necessário outros estudos para avaliar se adquirir e processar literatura interfere no oferecimento de outros produtos e/ou atrasa outras demandas. Entendemos que a tipologia de biblioteca aplicada na Francisco Montojos têm caracteristas escolares e universitárias.

Este estudo deu os primeiros passos no sentido de realizar uma avaliação das teorias e práticas executadas na Francisco Montojos referentes ao acervo e aos serviços relacionados. Surgiu a partir da observação do comportamento dos usuários frente aos suportes tecnológicos modernos, mas, com o tempo, foi constado que, antes de se analisar a reação dos sujeitos diante 
dos suportes tecnológicos, é necessário entender como os usuários se comportam com o acervo da biblioteca da qual a tecnologia faz parte.

É impossível definir se este trabalho foi inspirado por mudanças, ou se inspirará mudanças, mas, com certeza, ampliou a visão institucional desta pesquisadora. 


\section{REFERÊNCIAS}

ACCART, Jean-Philippe. Serviço de referência: do presencial ao virtual. Brasília: Brinquet de Lemos, 2012.

ALMEIDA, Maria Christina Barbosa de. Planejamento de bibliotecas e serviços de informação. Brasília: Briquet de Lemos/Livros, 2000.

ANNA, J. S. Desenvolvimento de coleções no sistema de bibliotecas da UFES: comparativo entre os modelos teóricos de Evans e Baughman e proposta de adequação ao modelo de Evans. Biblionline, v. 12, n. 2, 2016. Disponível em: <http://www.brapci.inf.br/v/a/20158>. Acesso em: 03 Jan. 20

ARAÚJO, Carlos Alberto Ávila. Estudos de usuários conforme o paradigma social da ciência da informação: desafios teóricos e práticos de pesquisa. Informação \& Informação, Londrina, v. 15, n. 2, p. 23 - 39, jul./dez. 2010.

BAUGHMAN, James C. Toward a structural approach to collection development. College \& Research Libraries, v. 38, n. 3, p. 241, p. 242, 1979.

BECKER, Caroline da Rosa Ferreira; FAQUETI, Marouva Fallgatter. Panorama das bibliotecas da Rede Federal de Educação Profissional, Científica e Tecnológica: um olhar sobre a gestão. Blumenau: IFC, 2015.

BORGES, Mônica Erichsen Nassif. O essencial para a gestão de serviços e produtos de informação. Revista Digital de Biblioteconomia e Ciência da Informação, Campinas, v.5, n. 1, p. 115-128, jul/dez. 2007- ISSN: 1678-765X.

BRASIL. Decreto n ${ }^{\circ} 7.566$, de 23 de setembro de 1909. Crêa [sic] nas capitais dos Estados da Republica Escolas de Aprendizes Artífices, para o ensino profissional primário e gratuito. Câmara dos Deputados. Disponível em: <http://www2.camara.leg.br/legin/fed/decret/19001909/decreto-7566-23-setembro-1909-525411-publicacaooriginal-1-pe.html> Acesso em: 13 fev. 2017.

BRASIL. Decreto ${ }^{\circ}$ 6.095, de 24 de abril de 2007. Estabelece diretrizes para o processo de integração de instituições federais de educação tecnológica, para fins de constituição dos Institutos Federais de Educação, Ciência e Tecnologia, no âmbito da Rede Federal de Educação Tecnológica. Palácio do Planalto. Disponível em: <http://www.planalto.gov.br/ccivil_03/_ato2007-2010/2008/lei/111892.htm>. Acesso em: 13 fev. 2017.

BRASIL. Lei no 4.320, de 17 de março de 1964. Estatui Normas Gerais de Direito Financeiro para elaboração e controle dos orçamentos e balanços da União, dos Estados, dos Municípios e do Distrito Federal. Palácio do Planalto. Disponível em:

<http://www.planalto.gov.br/CCivil_03/Leis/L4320.htm>. Acesso em: 07 set. 2016.

BRASIL. Lei no 8.666, de 21 de junho de 1993. Regulamenta o art. 37, inciso XXI, da Constituição Federal, institui normas para licitações e contratos da Administração Pública e 
dá outras providências. Palácio do Planalto. Disponível em:

<http://www.planalto.gov.br/ccivil_03/leis/L8666cons.htm>. Acesso em: 07 set. 2016.

BRASIL. Lei no 9.610, de 19 de fevereiro de 1978. Altera, atualiza e consolida a legislação sobre direitos autorais e dá outras providências. Palácio do Planalto. Disponível em: <http://www.planalto.gov.br/CCIVIL_03/leis/L9610.htm>. Acesso em: 07 set. 2016.

BRASIL. Lei n ${ }^{\circ} 10.753$, de 30 de outubro de 2003. Institui a Política Nacional do Livro. Palácio do Planalto. Disponível em: < http://www.planalto.gov.br/ccivil_03/leis/2003/L10.753.htm>. Acesso em: 07 set. 2016.

BRASIL. Lei 11.892, de 29 de dezembro de 2008. Institui a Rede Federal de Educação Profissional, Científica e Tecnológica, cria os Institutos Federais de Educação, Ciência e Tecnologia, e dá outras providências. Palácio do Planalto. Disponível em: <http://www.planalto.gov.br/ccivil_03/_ato2007-2010/2008/lei/111892.htm>. Acesso em: 07 set. 2016.

BRASIL. Medida Provisória ${ }^{\circ}$ 1.549, de 14 de março de 1997. Dispõe sobre a organização da Presidência da República e dos Ministérios e dá outras providências. Diário Oficial da União, Brasília, 17 mar. 1997a.

BRASIL. Decreto n ${ }^{\circ} 2.208$, de 17 de abril de 1997. Brasília, DF, 1997. Regulamenta o $\S 2^{\circ}$ do art. 36 e os arts. 39 a 42, da Lei nº 9.394/96. Diário Oficial da União, Brasília, Edição nº 74, 18 abr. $1997 \mathrm{~b}$.

BRYANT, Bonita. The organizational structure of collection development. Library Resources \& Technical Services, v. 31, n. 2, p. 111-122, 1987

CAMURÇA, Tatiana Apolinário; ARAÚJO, Islânia Fernandes; MORAIS, Sara Maria Peres de. A construção de um sistema integrado de bibliotecas no Instituto Federal do Ceará: motivação, dificuldade e expectativas. In: CONGRESSO BRASILEIRO DE BIBLIOTECONOMIA, DOCUMENTO E CIÊNCIA DA INFORMAÇÃO, 25., 2013. Florianópolis. Anais. Florianópolis: CBBD, 2013.

CAPURRO, Rafael. Epistemologia e ciência da informação. In: ENCONTRO NACIONAL DE PESQUISA EM CIÊNCIA DA INFORMAÇÃO, 5., 2003, Belo Horizonte. Anais... Belo Horizonte: ENANCIB, 2003.

CHOO, C. W. A organização do conhecimento: como as organizações usam a informação para criar significado, construir conhecimento e tomar decisões. São Paulo: Senac, 2003.

COGSWELL, James A. The organization of collection mangement functions in academic research libraries. Journal of Academic Librarianship, v. 13, n. 5, p. 269-271, 1987.

CBBI. Comissão Brasileira de Bibliotecas das Instituições da Rede Federal de Educação Profissional, Científica e Tecnológica - CBBI. 2017. Disponível em:

<http://www.cbbionline.org/quem-somos.html>. Acesso em: 04 maio 2018.

CORDA, María Cecilia. Gestão e mediação da informação em um serviço de referência digital no campo das ciências sociais. Brazilian Journal of Information Science: research 
trends, v. 6, n. 2, p. 89-104, jul./dez., 2012. Disponível em:

$<$ https://dialnet.unirioja.es/servlet/articulo?codigo=4330341>. Acesso: 03 set. 2017.

COSTA, Luciana F. da. Usabilidade do Portal de Periódicos da Capes. 2008. 236 f.

Dissertação (Mestrado em Ciência da Informação) - Centro de Ciências Sociais Aplicadas, Universidade Federal da Paraíba, João Pessoa, 2008.

CUNHA, Murilo Bastos da. Manual de fontes de informação. Brasília: Brinquet de Lemos, 2010.

D'ANGELO, Márcia. Caminhos para o advento da escola de aprendizes e Artificies de São Paulo. Um projeto das elites para uma sociedade assalariada. 2000. Dissertação (Mestrado em História) - Programa de Pós-graduação em História Econômica, Universidade de São Paulo, São Paulo.

DINIZ, Johnathan Pereira Alves. Gestão sustentável de bibliotecas: o uso do planejamento estratégico no Sistema Integrado de Bibliotecas (SIBI) para atender as demandas do Plano de Desenvolvimento Institucional do Instituto Federal Goiano. SEMINÁRIO NACIONAL DE BIBLIOTECAS UNIVERSITÁRIAS. 19., 2016. Anais... Manaus, IFLA, 2016.

FERREIRA, S. M. Novos paradigmas da informação e novas percepções do usuário. Ciência da Informação. Brasília, v. 25, n. 2, p. 217-223, maio/ago. 1996.

FIGUEIREDO, Nice Menezes de. Metodologia para a promoção do uso da informação. São Paulo: Nobel, 1990.

. Estudos de usuários. Brasília: IBICT, 1994.

FÓRUM NACIONAL DE BIBLIOTECÁRIOS DOS INSTITUTOS FEDERAIS, VI. Relatório do VI Fórum Nacional de Bibliotecários dos Institutos Federais de Educação, Ciência e Tecnologia. Petrolina, Instituto Federal do Sertão Pernambucano, 2011.

FOSKETT, D. J. Serviço de informação em bibliotecas. São Paulo: Polígono, 1969.

FROHMANN, Bernd. O caráter social, material e público da informação. In: FUJITA, M.; MARTELETO, R.; LARA, M. (Org.). A dimensão epistemológica da ciência da informação e suas interfaces técnicas, políticas e institucionais nos processos de produção, acesso e disseminação da informação. São Paulo: Cultura Acadêmica; Marília: Fundepe, 2008. p. 19-34.

. Serviço de informação no processo de cooperação Universidade-Empresa: proposta de um modelo de mediação institucional para micro e pequenas empresas. 2000. 271f. Tese (Doutorado em Ciência da Comunicação) - Escola de Comunicação e Artes, Universidade de São Paulo, São Paulo, 2000.

FUJINO, Asa; JACOMINI, Dulcinéia Dilva. Produtos e serviços de informação na sociedade do conhecimento: da identificação ao uso. In: GIANNASI-KAIMEN, Maria Júlia; CARELLI, Ana Esmeralda (Org.). Recursos informacionais para compartilhamento da informação: redesenhando acesso, disponibilidade e uso. Rio de Janeiro, E-Papers, 2007. p. 73-97. 
GIL, Antônio Carlos. Como elaborar projetos de pesquisa. 5.ed. São Paulo: Atlas, 2010.

GROGAN, D. A prática do serviço de referência. Brasília: Briquet de Lemos, 2001.

HERNÁNDEZ SAMPIERI, Roberto; FERNÁNDEZ COLLADO, Carlos; BAPTISTA

LUCIO, Pilar. Metodologia de pesquisa. 5. ed. Porto Alegre: Penso, 2013.

HOFFMANN, Wanda Aparecida Machado; BOCCATO, Vera Regina Casari; SANTOS, Cintia Almeida da Silva. O profissional da informação nos institutos federais de educação, ciência e tecnologia: um estudo de percepção. Revista EDICIC, v.1, n.3, p.127-142, Jul./Set. 2011. Disponível em: <http://www.edicic.org/revista/>. Acesso em 17 out. 2017

HJORLAND, Birger. Domain analysis in information science. Journal of Documentation, Londres, v. 58, n. 4, 2002, p. 122-162.

INSTITUTO NACIONAL DE ESTUDOS E PESQUISAS EDUCACIONAIS ANÍSIO TEIXEIRA. Censo Escolar da Educação Básica 2013: resumo técnico. Brasília: O Instituto, 2014. Disponível em:

$<$ http://download.inep.gov.br/educacao_basica/censo_escolar/resumos_tecnicos/resumo_tecni co_censo_educacao_basica_2013.pdf >. Acesso em: 05 ago. 2017.

JESUS, D. L. de; CUNHA, M. B. da. Produtos e serviços da web 2.0 no setor de referência das bibliotecas. Perspectivas em Ciência da Informação, v. 17, n. 1, p.110- 133, 2012.

Disponível em: < http://portaldeperiodicos.eci.ufmg.br/index.php/pci/article/view/885>.

Acesso em: 02 Mar. 2017.

KULTHAU, C. Inside the Search Process: Information Seeking from the User's Perspective, Journal of the American Society for Information Science, vol. 42, pp. 361-371, 1991. Disponível em: < http://comminfo.rutgers.edu/ belkin/612-05/kuhlthau-jasist-91.pdf〉

LANCASTER, Frederick Wilfrid. Avaliação de serviços de bibliotecas. Brasília: Briquet de Lemos, 2004.

MACEDO, Neusa Dias de. (Org.). Biblioteca escolar brasileira em debate: da memória profissional a um fórum virtual. São Paulo: SENAC, 2005.

MACIEL, Alba Costa; MENDONÇA, Marília Alvarenga Rocha. Biblioteca como organização. Rio de Janeiro: Interciência, 2000.

Princípios e reflexões sobre o serviço de referência e informação (continua). Revista Brasileira de Biblioteconomia e Documentação, v. 23, n. 1/4, p. 9-37, 1990. Disponível em: <http://www.brapci.inf.br/v/a/2800>. Acesso em: 24 Out. 2017.

MAGRILL, Rose Mary, HICKEY, Doralyn. Acquisitions management and collection development in libraries. Chicago: American Library Association, 1984. 
MIRANDA, A. C. U. C. Formação e desenvolvimento de coleções em bibliotecas especializadas. Informação \& Sociedade: Estudos, v. 17, n. 1, p. 87-94, 2007. Disponível em: <http://www.brapci.inf.br/v/a/4374>. Acesso em: 23 out. 2017.

MOORE, N. A sociedade da informação. In: A informação: tendências para um novo milênio. Brasília: Ibict, 1999.

MOUTINHO, Sonia Oliveira Matos. Práticas de leitur@ na cultura digital de alunos do ensino técnico integrado do IFPI - Campus Teresina do Sul. Dissertação. 2014. 186f. (Educação, Desenvolvimento e Tecnologias) - Universidade do Vale do Rio Sinos, 2014.

MOUTINHO, Sonia Oliveira Matos; LUSTOSA, Ianna Torres. As bibliotecas dos Institutos Federais frente às novas demandas gerenciais e informacionais causadas pela Lei 1.892/2008. In: Fórum Nacional de Bibliotecários dos Institutos Federais 6., , 2011, Petrolina. Anais... Petrolina: Instituto Federal do Sertão Pernambucano, 2011.

OLIVEIRA, Karin Bezerra de. As bibliotecas dos Institutos Federais e seu aspecto público. 2015. Trabalho de Conclusão de Curso (Graduação em Biblioteconomia e Ciência da informação) - Fundação Escola de Sociologia e Política de São Paulo, 2015.

ORTIGARA, Claudino. Reformas educacionais no período Lula (2003-2010): implementação nas instituições federais de ensino profissional. 2012. 309 p. Tese (doutorado) - Universidade Estadual de Campinas, Faculdade de Educação, Campinas, SP. Disponível em: $<$ http://www.bibliotecadigital.unicamp.br/document/?code=000879099>. Acesso em: 1 abr. 2017.

OSBORN, Charles B. Marketing the collection development aspects of serials control. In: LEE, Sul H., ed. Serials collection development: choices and strategies. Ann Arbor: Pierian Press, 1981.

PACHECO, Eliezer. Institutos Federais: uma revolução na educação profissional e tecnológica. Brasília: Santilla; São Paulo: Moderna, 2011.

PALM, Isis; NEHMY, Rosa Maria Quadros. Questões sobre a avaliação da informação: uma abordagem inspirada em Giddens. Perspect. Cienc. Inf., Belo Horizonte, v.3, n.2, p.81-95, jul./dez. 1998.

Pedrosa, José Geraldo; Santos, Oldair Glatson dos. A atuação de Francisco Montojos na constituição e na instituição do novo ensino industrial brasileiro (1934-1942). Revista Educação \& Tecnologia, n. 13, 2015.

PINTO, Daniela Maciel; SANTOS, Marcelo. Serviços de informação especializado como elemento de mediação: um estudo a partir da transferência de tecnologias no contexto da agricultura familiar brasileira. Tendências da Pesquisa Brasileira em Ciência da Informação, v.9, n.2, set./dez. 2016. 
RABELLO, Odília Clark Peres. Análise do campo de conhecimento relativo a usuários de biblioteca. 1980. 116 f. Dissertação (Mestrado em Administração de Bibliotecas) - Escola de Biblioteconomia, Universidade Federal de Minas Gerais, Belo Horizonte, 1980.

RIBEIRO, Maria Alice Rosa (Coord.). Trabalhadores urbanos e ensino profissional. Campinas: UNICAMP, 1986.

RODRIGUES, Maria Fernanda. Site que oferece livros para download gratuitos está ameaçado. O Estado de São Paulo. Disponível em:

$<$ http://cultura.estadao.com.br/noticias/literatura,site-que-oferece-livros-para-downloadgratuito-esta-ameacado,1601204>. Acesso em 07 set. 2015.

SANTOS, Cintia Almeida da Silva; BOCCATO, Vera Regina Casari; HOFFMANN, Wanda Aparecida Machado. Revisitando tipologias na formação de uma identidade sociocognitiva e históricoorganizacional de espaços de informação: as bibliotecas do instituto federal de São Paulo em cena. Inf. Prof., Londrina, v. 2, n. 1, p. 60 - 82, jan./jun. 2013. Disponível em: <http://www.uel.br/revistas/uel/index.php/infoprof/article/view/15749>

Os múltiplos olhares para as bibliotecas dos Institutos Federais de Educação, Ciência e Tecnologia. In: FÓRUM NACIONAL DE BIBLIOTECÁRIOS DOS INSTITUTOS FEDERAIS, 6., outubro, 2011, Petrolina. Anais... Petrolina: Instituto Federal do Sertão Pernambucano, 2011.

SANTOS, Maria Aparecida Brito. Regulamentação e concepção das bibliotecas nos Institutos Federais de Educação, Ciência e Tecnologia: em busca de sua historicidade e identidade. 2017. 150f. Dissertação (Ciência, Tecnologia e Sociedade) - Universidade Federal de São Carlos, 2017.

SANTOS, Raquel do Rosário; GOMES, Henriette Ferreira; DUARTE, Emeide Nóbrega. O papel da biblioteca universitária como mediadora da informação para construção de conhecimento coletivo. DataGramaZero. v. 15, n.2, abr. 2014. Disponível em: <http://www.dgz.org.br/abr14/Art_04.htm>. Acesso em 07 set. 2015.

SEPÚLVEDA, Maria Inês Moreira; ARAÚJO, Carlos Alberto Ávila. Realização de estudos de usuários na prática profissional bibliotecária: estudo de campo no sistema de bibliotecas da UFMG. Revista ACB: Biblioteconomia em Santa Catarina, Florianópolis, v.17, n.2, p.269287, jul./dez., 2012

SMIT, J. W.; BARRETO, A. A. Ciência da informação: base conceitual para a formação do profissional. In: VALENTIM, M. L. P. (org.). Formação do profissional da informação. São Paulo: Polis, 2002. P. 9-23.

Novas abordagens na organização, no acesso e na transferência da informação. In: 2009. p. 57-59. . Ciência da informação: múltiplos diálogos. Marília: Cultura Acadêmica,

SOUZA, Renata Junqueira de; MOTOYAMA, Juliane Francischeti Martins. A formação de leitores literários: o espaço como mediador. Raído. Dourados, MS, v.8 , n.17, jul./dez. 2014. Disponível em: 
<http://www.periodicos.ufgd.edu.br/index.php/Raido/article/viewFile/3553/2036>. Acesso em 22 ago. 2015.

VERGUEIRO, W. Desenvolvimento de coleções: uma nova visão para o planejamento de recursos informacionais. Ciência da Informação, v. 22, n. 1, p. 13-21, 1993. Disponível em: <http://www.brapci.inf.br/v/a/2402>. Acesso em: 23 out. 2017

Estabelecimento de políticas para o desenvolvimento de coleções: Revista Biblioteconomia, Brasília, v.15, n.2, p. 193-202, jul/dez. 1987.

Seleção de materiais de informação: princípios de técnicas. Brasília: Briquet de Lemos, 1995.

YIN, Robert K. Estudo de caso: planejamento e métodos. 4. ed. Porto Alegre: Bookman, 2010.

Estudo de caso: planejamento e métodos. 5. ed. Porto Alegre: Bookman, 2015.

WEITZEL, S.R. O desenvolvimento de coleções e a organização do conhecimento: suas origens e desafios. Perspectivas em Ciência da Informação, v.7, n.1, p.61-67, 2002.

Desenvolvimento de coleções: origem dos fundamentos contemporâneos.

TransInformação, Campinas, 24(3):179-190, set./dez., 2012.

WILSON, T. D. Recent trends in user studies: action research and qualitive methods. Information Research, v. 5, n. 3, s. p., Apr. 2000. 
APÊNDICE - QUESTIONÁRIO 


\section{QUESTIONÁRIO}

Este estudo tem por objetivo coletar dados sobre os usuários da biblioteca do IFSP - Campus São Paulo, que nos permitam compreender as necessidades de informação, grau de satisfação em relação aos serviços prestados e expectativas da comunidade acadêmica do campus São Paulo, em relação à biblioteca, visando subsidiar futuro projeto de reestruturação.

A pesquisa faz parte das atividades acadêmicas do Mestrado Profissional em Gestão da Informação USP e os participantes são protegidos pelo anonimato previsto no protocolo de ética da pesquisa na universidade.

Assim, solicitamos sua colaboração e nos colocamos à disposição para esclarecimentos de eventuais dúvidas.

Agradeço,

Rebeca Rodrigues rebeca.rodrigues@ ifsp.edu.br

rerbys @ $\underline{\text { usp.br }}$

\section{Indique seu vínculo com o IFSP - Campus São Paulo}

Marcar apenas uma oval.

Docente

Aluno

Técnico Administrativo

Funcionário terceirizado

2. Aluno, em qual categoria você está inserido? Marcar

apenas uma oval.

Técnico

Tecnologia

Licenciatura

Graduação

Especialização

Mestrado acadêmico

Mestrado profissional Cursos

de curta duração

3. Você utiliza a biblioteca? Marcar apenas uma oval. 
Sempre

Muitas vezes

Às vezes

Raramente

Nunca

4 Em qual contexto você utiliza o salão de estudos da biblioteca? Marcar apenas uma oval.

estudo individual com material emprestado da biblioteca estudo

individual com material próprio

estudo em grupo com material emprestado da biblioteca

Estudo em grupo com material próprio Não

utilizo

5. Você gostaria de sugerir outro contexto de uso para o salão de estudos da biblioteca?

6. Com qual finalidade você utiliza o acervo da biblioteca? Marque todas que se aplicam.

Suporte aos trabalhos acadêmicos exigidos pelos cursos

Recurso à pesquisa científica para o desenvolvimento de um estudo vinculado ao IFSP

Auxílio aos programas de extensão da instituição de ensino

Leitura recreativa/lazer

Apoio aos estudos destinados à Concursos Públicos

Desenvolvimento de Trabalho de Conclusão de Curso/Monografia/Dissertação Outro:

7. Na biblioteca do campus São Paulo, você procura com mais frequência que tipo de material?

Marcar apenas uma oval. 
Apenas as referências apontadas na bibliografia dos cursos

Materiais para pesquisas dos temas relacionados aos cursos

Literatura

Materiais para conhecimentos gerais Outro:

8. Em geral, você encontra na biblioteca o que procura? Marcar apenas uma oval.

Sempre

Muitas vezes

Às vezes

Raramente

Nunca

Outro:

9 Especificamente sobre os livros indicados na bibliografia de seu curso, você encontra as indicações na biblioteca? Marcar apenas uma oval.

Sempre

Muitas vezes

Às vezes

Raramente

Nunca

Outro:

10. Quando na biblioteca não tem o material bibliográfico indicado nos cursos, você... Marque todas que se aplicam.

Empresta de outras bibliotecas compra

o material indicado

Procura o material na versão digital na Internet

Empresta dos amigos Outro:

11. Dos

materiais da biblioteca, qual a sua preferência entre as versões?

Marcar apenas uma oval.

versão do livro digital empréstimo

do livro impresso 


\section{Quais serviços da biblioteca você utiliza?}

12. Empréstimo de livros Marcar apenas uma oval.

Conheço e utilizo com frequência

Conheço e utilizo de vez em quando

Conheço e não utilizo

Não conheço

13. Livros digitais da Person assinados pelo IFSP Marcar apenas uma oval.

Conheço e utilizo com frequência

Conheço e utilizo de vez em quando

Conheço e não utilizo

Não conheço

14 Empréstimo de revistas Marcar

apenas uma oval.

Conheço e utilizo com frequência

Conheço e utilizo de vez em quando

Conheço e não utilizo

Não conheço

15. Portal de Revistas Científicas online do

Instituto Federal São Paulo Marcar apenas uma

oval.

Conheço e utilizo com frequência

Conheço e utilizo de vez em quando

Conheço e não utilizo

Não conheço

16. CAPES Portal de Periódicos Marcar apenas uma oval.

Conheço e utilizo com frequência

Conheço e utilizo de vez em quando

Conheço e não utilizo 
Não conheço

17. Pergamum - Catálogo online do IFSP Marcar apenas uma oval.

Conheço e utilizo com frequência

Conheço e utilizo de vez em quando

Conheço e não utilizo

Não conheço

18. Normas ABNT e ISO assinadas pelo IFSP

Marcar apenas uma oval.

Conheço e utilizo com frequência

Conheço e utilizo de vez em quando

Conheço e não utilizo

Não conheço

\section{Como você avalia a coleção de livros e os serviços voltados ao acervo?}

19. Qualidade dos títulos disponíveis Marcar

apenas uma oval.

Excelente

Bom

Regular Ruim

20 Estado de conservação dos exemplares Marcar

apenas uma oval.

Excelente

Bom

Regular

Ruim

21. Quantidade de exemplares disponíveis Marcar apenas uma oval. 
$\bigcirc$ Excelente

Bom

Regular

Ruim

Powered by

: Google Forms 
ANEXO - POLÍTICA DE DESENVOLVIMENTO DE COLEÇÕES DAS BIBLIOTECAS DO IFSP 
Portaria n $^{0}$ 967, de 09 de março de 2015

Aprova Politica de Desenvolvimento de Coleções das Bibliotecas do IFSP.

O REITOR DO INSTITUTO FEDERAL DE EDUCAÇÃO, CIÊNCIA E TECNOLOGIA DE SÃO PAULO, no uso de suas atribuições legais conferidas pelo Decreto de 8 de abril de 2013, publicado no Diário Oficial da União em 9 de abril de 2013 e considerando o Memorando $n^{\circ} 052 / \mathrm{PRE} / \mathrm{DAA}$, de 05 de março de 2015,

\section{RESOLVE:}

APROVAR a Política de Desenvolvimento de Coleções das Bibliotecas do Instituto Federal de Educação, Ciência e Tecnologia de São Paulo - IFSP, com a finalidade de deixar clara a filosofia norteadora das atividades das bibliotecas do IFSP no que diz respeito às suas coleções, e de tornar público o relacionamento entre o desenvolvimento de tais coleções e os objetivos da instituição a que elas servem.

Dê ciência.

Publique-se.

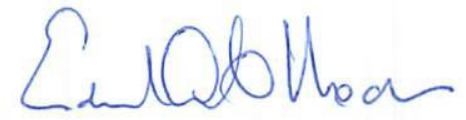

EDUARDO ANTONIO MODENA 


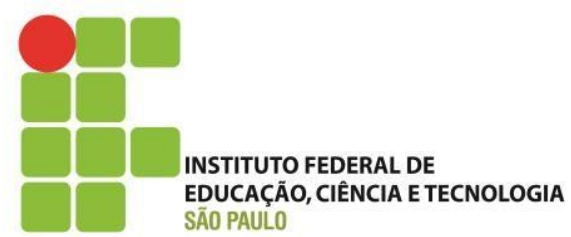

POLÍTICA DE DESENVOLVIMENTO DE COLEÇÕES DAS BIBLIOTECAS DO IFSP

SÃO PAULO

2015 


\section{ELABORAÇÃO}

Angela Halen Claro Bembem

Bibliotecária-Documentalista

Coordenadora de Bibliotecas

Pró-Reitoria de Ensino

Etiene Siqueira Rocha

Bibliotecária-Documentalista Campus

Cubatão

O material é oriundo das discussões do Grupo de Trabalho 3 -Desenvolvimento de Coleções, nomeado pela portaria $n^{\circ}$ 2.000, de 6 de maio de 2014. 
"Uma biblioteca não é meramente um aglomerado de livros colocados juntos por uma série de circunstâncias fortuitas, mas uma criação significativa, projetada para, intencionalmente, estimular no usuário uma atividade cerebral.” Jesse Shera, 1978 


\section{SUMÁRIO}

1 INTRODUÇÃO

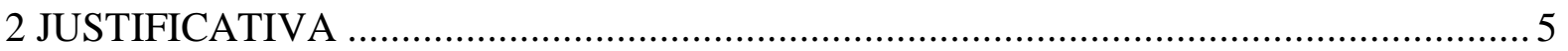

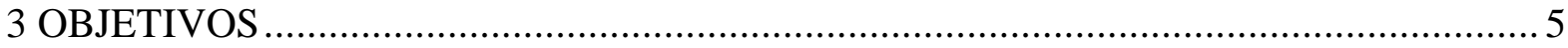

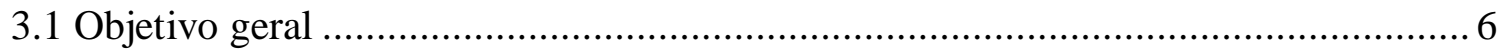

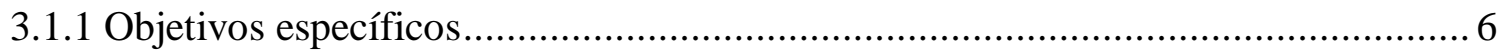

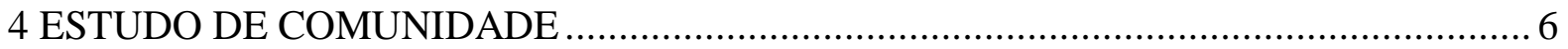

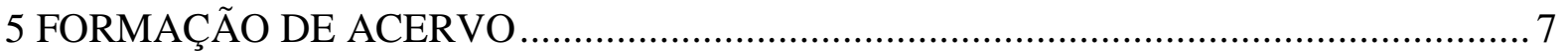

6 RESPONSABILIDADE PELA POLÍTICA DE DESENVOLVIMENTO DE COLEÇÕES 7

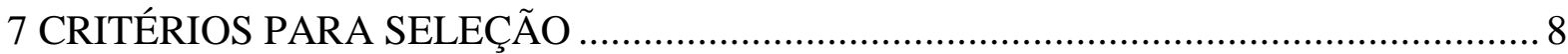

7.1 Critérios de Seleção para livros ............................................................................

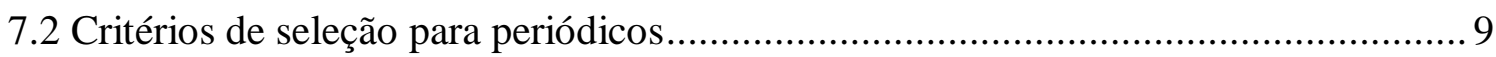

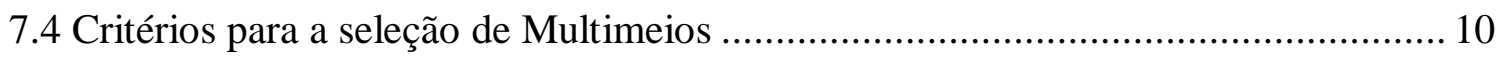

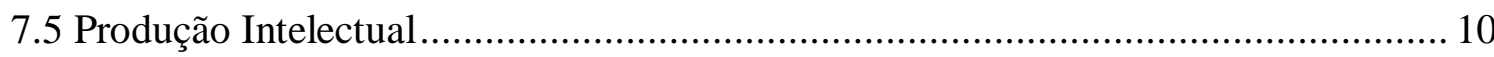

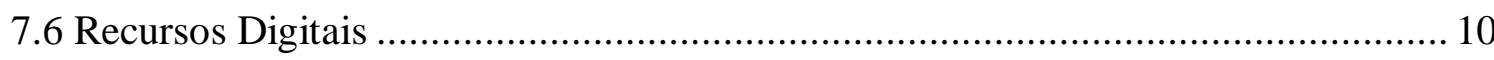

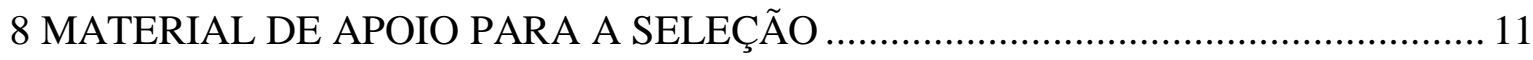

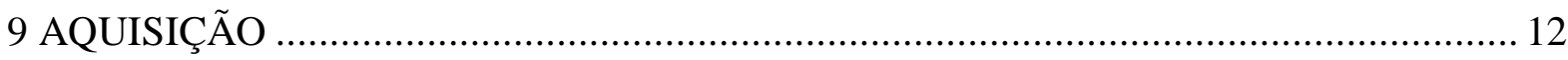

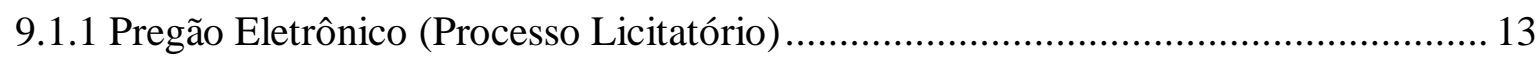

9.1.2 Cotação Eletrônica (Dispensa de Licitação) ……………………………………….... 13

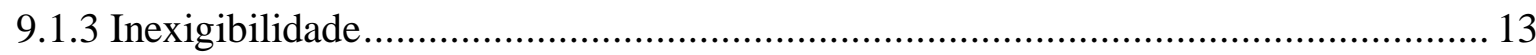

9.1.4 Sistema de Registro de Preço (SRP) ................................................................. 14

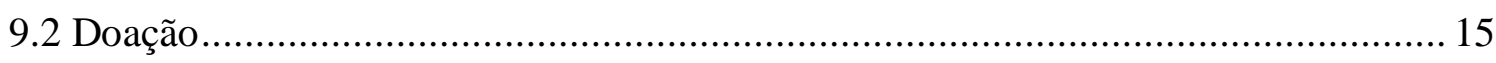

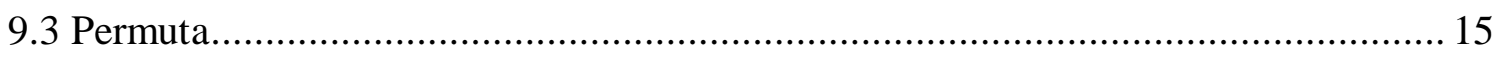

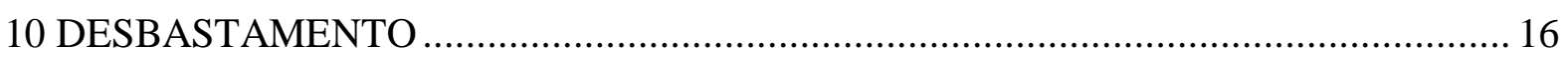

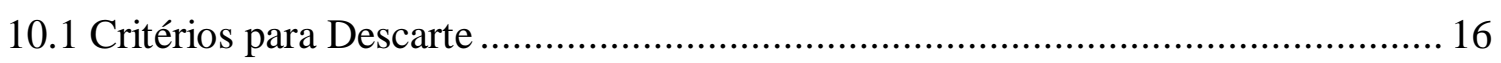

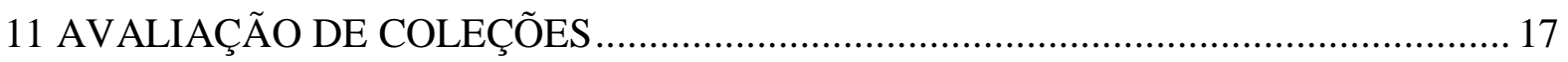

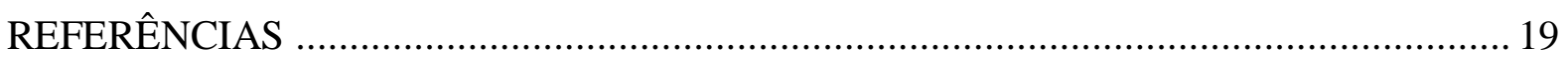

APÊNDICE A - FORMULÁRIO DE SUGESTÃO DE USUÁRIO_........................................ 22

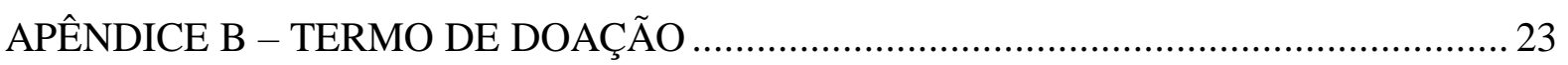




\section{INTRODUÇÃO}

A política de desenvolvimento de coleções das bibliotecas do Instituto Federal de Educação, Ciência e Tecnologia de São Paulo (IFSP) tem como objetivo definir os critérios para o desenvolvimento de coleções e atualização do acervo de forma quantitativa e qualitativa. Fato esse que possibilita a racionalização e otimização dos recursos financeiros e humanos disponíveis nas bibliotecas dos campi. Esse instrumento político-administrativo visa tornar público os objetivos do acervo, bem como assegurar que as necessidades informacionais dos usuários das bibliotecas do IFSP sejam atendidas. Paralelamente aos objetivos norteadores, busca-se evitar os gastos públicos desnecessários como o crescimento desorganizados das bibliotecas, bem como busca-se o controle dos recursos financeiros com a aquisição do acervo.

O documento compõe os objetivos e metas das Bibliotecas do IFSP, bem como, explana de forma substancial e consistente acerca de todas as informações necessárias ao processo de desenvolvimento de coleções, servindo de ferramenta básica, imprescindível para a tomada de decisões na formação de acervo. Nesse sentido, a Política de Desenvolvimento de Coleções permite a sistematização da formação do acervo e a aplicação de instrumentos metodológicos de trabalho para fundamentar as ações relativas ao desenvolvimento de coleções.

Tendo em vista os objetivos e metas da política, se faz necessário destacar o perfil institucional e histórico do IFSP, considerando sua ampla abrangência de atuação educacional, a qual se difere das demais instituições de ensino tradicional, uma vez que contempla do ensino básico à pósgraduação.

Por meio de decreto do então Presidente da República, Nilo Peçanha, em 1909, iniciase o ensino industrial no país. A Escola de Aprendizes Artífices de São Paulo é inaugurada em 1910 e oferecia os cursos de tornearia, mecânica e eletricidade. Foi reconhecida pela sociedade paulistana por sua excelência no ensino público gratuito de qualidade, "a escola não admitia nenhum aluno abaixo da nota mínima. Em 1959 havia 35 vagas e 73 candidatos, mas só foram aprovados 20." (O HOMEM E A TÉCNICA...,1986).

Durante seus 105 anos de história, recebeu, também, os nomes de Escola Técnica Federal de São Paulo e Centro Federal de Educação Tecnológica de São Paulo. Em 2008, passou a ter relevância de universidade, com a alteração para Instituto, destacando-se, assim, pela autonomia (INSTITUTO FEDERAL DE EDUCAÇÃO, CIÊNCIA E TECNOLOGIA DE SÃO PAULO, 2014b).

Com a mudança, o Instituto Federal de São Paulo passou a destinar 50\% das vagas para os cursos técnicos e, no mínimo, 20\% das vagas para cursos de licenciatura, sobretudo nas áreas de Ciências e da Matemática. Complementarmente, continuará oferecendo cursos de formação inicial e continuada, tecnologias, engenharias e pós-graduação.

O IFSP é organizado em estrutura multicampi e possui aproximadamente 22 mil alunos matriculados nos 38 campi e mais 4 mil alunos distribuídos nos 23 polos de educação a distância divididos pelo estado de São Paulo.

As finalidades do Instituto Federal referem-se à: ofertar educação profissional e tecnológica em todos os seus níveis e modalidades formando e qualificando cidadãos; desenvolver a educação profissional e tecnológica como processo educativo; constituir-se em centro de 
excelência na oferta do ensino de ciências, em geral, e de ciências aplicadas, em particular, estimulando o desenvolvimento de espírito crítico, voltado à investigação empírica; desenvolver programas de extensão e de divulgação científica e tecnológica; realizar e estimular a pesquisa aplicada, a produção cultural, o empreendedorismo, o cooperativismo e o desenvolvimento científico e tecnológico (BRASIL, 2008).

Assim, a formação adequada do acervo é necessária para o bom andamento das bibliotecas que atuam como subsídio teórico para as atividades de ensino, pesquisa e extensão do Instituto Federal de São Paulo, bem como atuam como suporte para o aparato investigativo de cada campus. Desta forma, a aquisição de materiais, abrangendo obras de referência, livros, periódicos e multimeios deve ser norteada por uma política cujos objetivos da instituição e da comunidade acadêmica sejam balizadores.

Outro aspecto a ser considerado devido a sua importância para o desenvolvimento de coleções é a imparcialidade no processo de seleção e aquisição de materiais. É um aspecto que se refere à postura ética do profissional bibliotecário ao garantir que os materiais adquiridos estejam alinhados aos objetivos do acervo e da instituição e não aos valores pessoais do bibliotecário.

Como destaca Figueiredo (1986, p.39) ao mencionar os princípios norteadores do processo de desenvolvimento de coleções: "mantenha imparcialidade na seleção; não favoreça interesses ou opiniões particulares; em assuntos controversos ou sectários".

\section{JUSTIFICATIVA}

A Política de Desenvolvimento de Coleções do Sistema de Bibliotecas do IFSP justifica-se na medida em que permite uma perspectiva sistêmica para o processo de desenvolvimento de coleção ao esclarecer a importância de todas as etapas que compõem o processo, bem como estabelece parâmetros norteadores para a composição do acervo em conformidade com os interesses de seus usuários e a missão do IFSP.

Por meio da política é possível focar nos interesses e necessidades dos usuários em consonância com os objetivos e metas das bibliotecas, facilitando o processo de tomada de decisão ao mapear todas as etapas e critérios que envolvem o desenvolvimento de coleções, permitindo assim que o processo possa ser realizado pelo bibliotecário de forma racional quanto à alocação de recursos e ao atendimento dos objetivos da coleção (VERGUEIRO, 1989). A partir da política de desenvolvimento de coleções critérios de seleção são estabelecidos para auxiliar a aquisição, avaliação e descarte do material, permitindo que a coleção cresça quantitativamente e qualitativamente de forma equilibrada e coerente, de acordo com o orçamento e sem desperdício de gastos públicos da União.

A política de Desenvolvimento de Coleções apresenta ainda um papel fundamental para a administração das bibliotecas, o qual se configura na transparência da filosofia do trabalho do bibliotecário, no que se refere à seleção e à aquisição de materiais. Conforme Vergueiro (1989), trata-se de tornar público qual o relacionamento do bibliotecário com planejamento da coleção e os objetivos da instituição. 


\section{OBJETIVOS}

\subsection{Objetivo geral}

Direcionar de maneira coerente o desenvolvimento das coleções das bibliotecas do IFSP atrelando esse processo aos objetivos do Instituto Federal de São Paulo.

\subsubsection{Objetivos específicos}

a) Normalizar o processo de seleção e aquisição de material bibliográfico;

b) Orientar e direcionar o processo de seleção, em relação à quantidade e qualidade, de acordo com as características de cada curso oferecido pela instituição;

c) Atualizar permanentemente o acervo, permitindo o crescimento racional e equilibrado do mesmo nas áreas de atuação da instituição;

d) Atender a demanda informacional da comunidade acadêmica;

e) Traçar diretrizes para o descarte de material;

f) Nortear os procedimentos de avalição de coleções.

\section{ESTUDO DE COMUNIDADE}

O estudo de comunidade da biblioteca tem como objetivo conhecer as necessidades dos usuários da biblioteca, dos não-usuários, e dos usuários potenciais a fim de proporcionar a adequação do acervo as reais necessidades informacionais dos mesmos. Isso porque há o risco dos bibliotecários se atentarem apenas para as necessidades dos usuários reais, ou seja, aqueles que já frequentam a biblioteca. Vergueiro (1989) chama atenção para o papel essencialmente democrático das bibliotecas, a qual deve atender às necessidades de todos os membros de sua comunidade.

O estudo de comunidade deve ser uma atividade contínua devido ao perfil dinâmico dos usuários da biblioteca, bem como deve buscar identificar os seguintes aspectos:

O perfil socioeconômico da comunidade escolar;

Os materiais de informação utilizados pela comunidade escolar;

Delineamento de aspectos do comportamento dos usuários da biblioteca com relação à informação (preferência de formato, dificuldade de acesso, múltiplos aspectos culturais, educacionais); $\square$ As necessidades informacionais dos usuários.

Para tanto, faz-se necessária a utilização de instrumentos metodológicos a fim de investigar e identificar as características, interesses e necessidades da comunidade acadêmica, 
como por exemplo, o uso de questionário eletrônico que auxilia na tabulação e manipulação dos dados.

A aplicação periódica de tal questionário deve embasar as tomadas de decisão no que se refere a todo o processo de desenvolvimento de coleções para que o acervo apresente relação direta com a comunidade usuária do IFSP, a qual pretende servir.

\section{FORMAÇÃO DE ACERVO}

O acervo deverá ser constituído de acordo com os recursos orçamentários contemplando os diversos tipos de materiais, nos diferentes formatos:

a) Livros;

b) Obras de referência: dicionários linguísticos, bibliográficos e especializados e enciclopédias;

c) Periódicos: jornais, revistas especializadas e gerais;

d) Multimeios: DVD, CD-ROM, etc;

e) Produção intelectual da instituição;

f) Recurso digitais: e-books, bases de dados.

Os materiais que irão compor o acervo devem apoiar às atividades de ensino, pesquisa e extensão dos campi, respaldados pelos programas das disciplinas e programas de pesquisa e extensão. É necessário também que o acervo possua obras de referência em áreas e assuntos específicos dos cursos de cada campus.

O acervo tem como objetivo atender a toda demanda interna do Instituto (alunos, professores e técnicos-administrativos) e público externo, fornecendo apoio ao desenvolvimento das atividades acadêmicas e dando prioridade ao atendimento das necessidades informacionais dos alunos da instituição.

\section{RESPONSABILIDADE PELA POLÍTICA DE DESENVOLVIMENTO DE COLEÇÕES}

A responsabilidade acerca da aplicação da política será dos bibliotecários-documentalistas dos campi do IFSP, sendo que uma comissão consultiva será formada a fim de assessorar todo o processo de seleção e aquisição de acervo. A comissão consultiva tem como função auxiliar os bibliotecários na decisão quanto ao processo de seleção e aquisição de materiais, sendo que ela deve ser formada pelos bibliotecários de cada campus e coordenadores das áreas de especificidades de cada campus do Instituto, sendo designada por portaria pelo diretor geral de cada campus. 
Os procedimentos relativos à seleção serão homogeneizados para garantir a qualidade em todo o processo de desenvolvimento das coleções das bibliotecas do IFSP.

Serão respeitadas as especificidades de cada Biblioteca, no que concerne às atividades voltadas para as áreas de conhecimento em que atuam e as características dos campi, em que estão inseridas.

\section{CRITÉRIOS PARA SELEÇÃO}

O processo de seleção dos materiais para a aquisição é influenciado por quatro grandes fatores, a saber: o assunto, os usuários, o documento e o preço (VERGUEIRO, 1995), ou seja, todo o processo de seleção engloba tais aspectos a fim realizar um processo que incorpore questões pertinentes às rotinas das bibliotecas. Assim, os critérios de seleção elencados devem, necessariamente, refletir a tais elementos. Dessa forma, considera-se como critérios de seleção, os descritos abaixo:

a. Autoridade: Qualidade do material a partir da respeitabilidade dos autores, editores, tradutores.

b. Atualidade do conteúdo: Adequação do conteúdo abordado no material aos assuntos vigentes nas respectivas áreas de conhecimento.

c. Cobertura: Deve-se verificar se a obra possui o nível de vocabulário e conhecimento compatível ao conhecimento técnico dos usuários do IFSP;

d. Precisão: Exatidão e rigor nos assuntos abordados;

e. Imparcialidade: Os assuntos devem ser apresentados de forma justa, sem a existência de preconceitos;

f. Custo: O custo da aquisição do material está de acordo com a verba disponível para a Biblioteca;

g. Idioma: o bibliotecário responsável deve ter conhecimento, através do estudo de comunidade, qual língua é acessível e compreensível aos usuários

h. Relevância/interesse: Através do estudo de comunidade, o bibliotecário deve julgar qual a utilidade do título para o campus e também deve considerar as coleções que já existem na biblioteca;

i. Durabilidade: Obsolescência do formato;

j. Acesso: Compatibilidade dos recursos aos dispositivos eletrônicos da biblioteca;

k. Suporte: O bibliotecário deve observar o tipo de suporte do material e a viabilidade do mesmo. 
7.1 Critérios de Seleção para livros

Os livros devem ser selecionados mediante os seguintes critérios, em ordem de prioridade:

\section{Autoridade;}

2. Atualidade do conteúdo;

3. Cobertura;

4. Precisão;

5. Imparcialidade;

6. Custo;

7.2 Critérios de seleção para periódicos

Os periódicos devem ser selecionados mediante os seguintes critérios, em ordem de prioridade:

\section{Atualidade do conteúdo;}

2. Autoridade;

3. Precisão;

4. Custo;

\section{Idioma;}

Os periódicos científicos estão entre as exigências de composição de acervo das bibliotecas na avaliação dos cursos superiores pelo MEC, sendo sua importância prevista no Instrumento de Avalição de Cursos de Graduação Presencial e à Distância (MINISTÉRIO DA EDUCAÇÃO, 2012). É necessária a seleção de periódicos correntes e indexados.

Periódicos que não apresentam Qualis poderão ser incluídos no acervo desde que apresentem conteúdos relevantes e de interesse aos usuários.

A biblioteca deve selecionar jornais com abrangência municipal, estadual e nacional atendendo os seguintes critérios de seleção:

1. Confiabilidade;

2. Imparcialidade;

3. Cobertura do conteúdo. 


\subsection{Critérios para seleção de obras de referência}

As obras de referência devem ser selecionadas mediante os seguintes critérios, em ordem de prioridade:

\section{Autoridade;}

\section{Relevância/interesse;}

\section{Atualidade do conteúdo;}

\section{Precisão.}

7.4 Critérios para a seleção de Multimeios

Para a seleção de material audiovisual, fica estabelecido que deverão ser respeitados os seguintes critérios de seleção:

\section{Qualidade do material;}

\section{Confiabilidade;}

\section{Adequação ao usuário;}

\section{Imparcialidade;}

6. Custo;

\section{Durabilidade.}

\subsection{Produção Intelectual}

A produção intelectual será incorporada ao repositório Digital IFSP, o qual encontra-se em prospecção. Esse contará com uma política especifica, a qual deverá ser elaborada por representantes do corpo docente e dos bibliotecários dos campi do IFSP.

\subsection{Recursos Digitais}

Os recursos digitais são elementos fundamentais para o desenvolvimento das bibliotecas do instituto, pois são uma inovação do formato "livro" que propicia várias vantagens para os usuários e para a instituição, tais como: reunião de vários recursos em um documento; facilidade no acesso; possibilidade de acessibilidade para os deficientes; redução dos gastos orçamentários; e auxílio no gerenciamento dos espaços físicos limitados destinados para a formação do acervo. 
Corroborando com a ideia, Rosseto (2008, p.102) afirma que

A mudança radical sofrida pelo livro naquele momento [criação da impressa por Gutemberg] é da mesma magnitude quando se aplicam as tecnologias de informação e comunicação na produção e divulgação do livro a partir dos últimos anos do século XX.

Assim, os recursos digitais são de suma importância para o IFSP como instituição com foco em inovação e tecnologia. Dessa forma, tais recursos digitais serão selecionados de acordo com os seguintes critérios:

\section{Autoridade;}

\section{Atualidade do conteúdo;}

\section{Cobertura;}

\section{Precisão;}

\section{Imparcialidade;}

\section{Custo;}

\section{Acesso;}

\section{Suporte;}

Conforme já mencionado, o processo de seleção deve ainda considerar o interesse dos usuários da comunidade acadêmica, haja vista a importância dos mesmos para as bibliotecas no que se refere ao papel elementar dos usuários para funcionalidade das bibliotecas. Ressaltando, a importância da postura ética e impessoal do profissional ao longo do processo.

\section{MATERIAL DE APOIO PARA A SELEÇÃO}

Para que a seleção possa ser feita adequadamente os bibliotecários necessitam de materiais de apoio com conhecimentos mínimos acerca dos materiais a serem adquiridos. Há fontes de informação que atuam como recurso para os bibliotecários no momento de seleção dos itens, a saber:

- Materiais distribuídos por editores, distribuidores e livrarias (catálogos e listagens);

- Bibliografias gerais e especializadas;

- Catálogos, listas de novas aquisições e boletins bibliográficos de outras bibliotecas;

- Visitas a livrarias, exposições literárias, feiras de livros e eventos similares;

- Resenhas em jornais, revistas, sites ou blogs especializados; 
- Sugestões de usuários (docente, discentes e técnico-administrativos). Tais sugestões serão recebidas por meio da opção de sugestão disponível no catálogo online Pergamum, ou por meio de formulário impresso, conforme o Apêndice A.

Considerando a importância da transparência no processo de seleção e do trabalho do bibliotecário, a documentação referente à seleção dos materiais deve ser arquivada pelo período de cinco anos.

Para garantir o sucesso e qualidade do processo de seleção do acervo, o corpo docente e biblioteca devem trabalhar em sintonia. Recomenda-se, considerar os seguintes aspectos:

- Comunicação entre bibliotecários e coordenadores de cursos acerca das possíveis atualizações dos projetos pedagógicos dos cursos;

- Priorização dos acervos dos cursos em implantação e/ou em fase de reconhecimento;

- Atenção às áreas de pesquisa cientifica em desenvolvimento no campus.

\section{AQUISIÇÃO}

A etapa de aquisição, dentro do processo de desenvolvimento de coleções, é exclusivamente administrativa. Isso porque ela tem a função de encontrar e assegurar a posse para a biblioteca dos itens definidos na fase de seleção. Seu foco principal é possibilitar acesso rápido ao material desejado, valendo-se no menor custo possível para isso (VERGUEIRO, 1987). O processo de aquisição acontece no estabelecimento de uma parceria entre a biblioteca e a Gerência Administrativa.

É importante destacar que o quantitativo de aquisição dos materiais previstos nas bibliografias básicas e complementares dos cursos de graduação do IFSP devem estar de acordo com o Instrumento de Avaliação Presencial e a Distância disponibilizado pelo MEC ${ }^{1}$. Dentre as modalidades de aquisição possíveis no âmbito das bibliotecas do IFSP têm-se a compra, a doação e a permuta, as quais serão tratadas a seguir.

\subsection{Compra}

De acordo com a Constituição Federal, art.37, inciso XXI, e o art. $2^{\circ}$ da Lei n. ${ }^{\circ} 8.666 / 93$, que institui normas para licitações e contratos da Administração Pública e dá outras providências, para a contratação de serviços ou aquisição ${ }^{2}$ de bens para a Administração Pública, o procedimento oficial é a realização de licitação.

\footnotetext{
${ }^{1}$ Em 2015, ano da publicação da Política de Desenvolvimento de Coleções das Bibliotecas do IFSP, o último instrumento disponibilizado era o da edição de 2012. É necessário o acompanhamento contínuo das possíveis atualizações do mesmo.

${ }^{2}$ Aquisição nos termos da Lei pode ser entendida como compra.
} 
Como o IFSP se enquadra nesse perfil, por ser uma autarquia pública federal, toda e qualquer forma de compra de materiais para o acervo da biblioteca deve ser feita por essa modalidade, a não ser nos casos em que não se faz licitação (Art.17, Lei nº.666/93), ou em que a licitação é dispensável (Art.24, Lei n8.666/93), ou ainda quanto a licitação é inexigível (Art.25, Lei

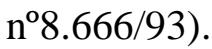

Sendo assim, dentre as formas compra de materiais ou contratação de serviços tem-se o pregão eletrônico, a cotação eletrônica, a inexigibilidade de licitação e o Sistema de Registro de Preço.

\subsubsection{Pregão Eletrônico (Processo Licitatório)}

De acordo com o Ministério do Planejamento, Orçamento e Gestão (2006), o pregão eletrônico é uma modalidade de licitação para aquisição de bens e serviços comuns, no qual os padrões de qualidade e desempenho possam ser claramente definidos por edital mediante especificações usuais no mercado.

A Lei que institui tal modalidade de licitação é a n $n^{\circ} 10.520$, de 17 de julho de 2002. O Decreto $\mathrm{n}^{\circ} 5.450$, de 31 de maio de 2005, regulamenta e torna obrigatório que o pregão seja realizado de forma eletrônica, a não ser em situações que a inviabilidade do processo possa ser justificada por autoridade competente (MINISTÉRIO DO PLANEJAMENTO, ORÇAMENTO E GESTÃO,

2014?).

A principal característica dessa modalidade é a celeridade nos processos licitatórios, fato que possibilita a redução de custos para Administração Pública. Além disso, o pregão eletrônico tem se consolidado como a principal forma de contratação do Governo Federal (MINISTÉRIO DO PLANEJAMENTO, ORÇAMENTO E GESTÃO, 2014?).

\subsubsection{Cotação Eletrônica (Dispensa de Licitação)}

A aquisição de materiais de consumo ou permanente que estiverem de acordo com o Art. 24, II, da Lei n ${ }^{\circ} 8.666 / 93$, ou seja, a aquisição em que a licitação é dispensável, deve ser efetuada, de preferência, por Cotação Eletrônica, conforme se observa no parágrafo $2^{\circ}$, Art. 4 do Decreto n. $^{\circ}$

5.450/05, regulamentado pela Portaria MPOG n. ${ }^{\circ 306 / 01}$ (IFSP, 2014). Para efetuar tal tipo de contratação, de acordo com o IFSP (2014), devese observar o valor previsto na Portaria do IFSP n. ${ }^{\circ} 1.003 / 14$, que refere-se aos procedimentos de descentralização, o qual limita-se a R\$ 8.000,00 no exercício (ano) por natureza de despesas, a saber: material de consumo, serviço e material permanente. Além disso, deve-se evitar o fracionamento da aquisição/ contratação de serviços com o objetivo de se dispensar a licitação.

\subsubsection{Inexigibilidade}


A Inexigibilidade de licitação é a modalidade de compra ou contratação de serviços em que tem-se o fornecimento do bem ou serviço por um fornecedor único e exclusivo.

Para que tal modalidade de compra ocorra é necessário comprovar a situação de fornecedor único e exclusivo, bem como que a escolha do objeto se deu por razões técnicas, e que somente ele atenderá as necessidades da instituição.

\subsubsection{Sistema de Registro de Preço (SRP)}

Entende-se como Sistema de Registro de Preços (SRP) o conjunto de procedimento para se registrar formalmente preços relativos à prestação de serviços ou aquisição de bens visando contratações futuras (CONTROLADORIA GERAL DA UNIÃO, 2014).

É importante destacar que o SRP não é uma nova modalidade de licitação. A forma de licitar é a tradicional, na modalidade de pregão eletrônico. A diferença está na contratação ou aquisição, uma vez que elas podem acontecer de imediato ou posteriormente, desde que não ultrapasse a validade da ata, que é de um ano (COMPRASNET, 2014?).

Como normativos que regulamentam o SRP, têm-se a Lei no 8.666/1993, a qual estabeleceu em seu art. 15, inciso II, que as compras, sempre que possível, devem ser efetuadas por meio de SRP. No âmbito federal, o assunto é tratado no Decreto $\mathrm{n}^{\circ} 7.892 / 2013$, o qual regulamenta o Sistema de Registro de Preços previsto no art. 15 da Lei no 8.666, de 21 de junho de 1993, e revoga os decretos $n^{\circ} 3.931 / 2001$ e o $n^{\circ}$ 4.342/2002 (CONTROLADORIA GERAL DA UNIÃO, 2014).

De acordo com o Decreto $\mathrm{n}^{\mathrm{o}} 7.892 / 2013$, Art. $3^{\circ}$, incisos de I a IV, o SRP pode ser adotado nas seguintes hipóteses:

I - quando, pelas características do bem ou serviço, houver necessidade de contratações frequentes;

II - quando for conveniente a aquisição de bens com previsão de entregas parceladas ou contratação de serviços remunerados por unidade de medida ou em regime de tarefa;

III - quando for conveniente a aquisição de bens ou a contratação de serviços para atendimento a mais de um órgão ou entidade, ou a programas de governo; ou

IV - quando, pela natureza do objeto, não for possível definir previamente o quantitativo a ser demandado pela Administração (BRASIL, 2013, não paginado).

Segundo o portal Compras Net (2013?, não paginado), a vantagem da

SRP é a

redução de gastos, uma vez que anteriormente para um mesmo objeto cada órgão realizaria a sua própria licitação e atualmente, com a regulamentação do SRP, tal contratação ou aquisição para os diversos 
órgãos pode ser realizada por meio de uma única licitação, visto que os preços registrados na Ata têm validade de 1 ano, assim sendo a contratação de serviços ou aquisição de bens para os órgãos integrantes do SRP - gerenciador ou participantes pode ser feita de imediato, bastando para isso que os preços registrados permaneçam dentro da faixa praticada pelo mercado.

\subsection{Doação}

Os critérios para a seleção de doações devem ser rigorosamente os mesmo dos empregados para a seleção de materiais a serem adquiridos por compra (VERGUEIRO, 1989). Isso leva a considerar que as bibliotecas do IFSP não devem aceitar doações de materiais que elas não adquirissem se pudessem comprar.

Vale ressaltar que não serão incorporados no acervo materiais danificados ou em mau estado de conservação, cópias reprográficas, volumes avulsos de dada coleções, ou materiais religiosos, pornográficos ou que incitem a violência.

Os materiais recebidos por doação poderão ser oriundos de pessoa física ou jurídica. A apresentação e entrega dos itens a serem doados devem ser realizadas, exclusivamente, nas bibliotecas das unidades e entregues aos servidores do setor.

As bibliotecas do IFSP poderão decidir em receber ou não os materiais disponibilizados. Optando pelo recebimento, elas terão autonomia para incorporar, repassar ou descartar o material doado.

Para o recebimento dos materiais, a biblioteca deverá solicitar ao doador o preenchimento do termo de doação (Apêndice B), anexando a ela a lista de materiais recebidos por doação.

O processamento técnico e incorporação no acervo dos itens recebidos por doação serão realizados segundo os tramites normais dos demais itens da biblioteca, ou seja, de acordo com as necessidades dos usuários e disponibilidade da equipe técnica. Para a incorporação do item como bem permanente da instituição será necessário que o bibliotecário solicite à Coordenadoria de Patrimônio do campus que providencie os números de patrimônio para os itens recebidos por doação.

\subsection{Permuta}

A permuta consiste num processo em que instituições parceiras trocam entre si materiais, sendo na maioria das vezes livros ou periódicos. Esses materiais podem ser os publicados pela própria instituição ou materiais que tenham sido adquiridos por compra ou doação que não atendem ou deixaram de atender às demandas dos usuários.

Essa modalidade de aquisição será realizada por meio de envio de lista de materiais disponíveis, semestralmente, para as instituições parceiras. Considera-se como instituições 
parceiras os campi do IFSP, os campi dos Institutos Federais de outros estados, e as instituições de ensino com atuação semelhante a do IFSP. A lista a ser enviada para as instituições deve apresentar a referência dos itens a serem disponibilizados e quantidade de exemplares existentes.

\section{DESBASTAMENTO}

O desbastamento é uma etapa do processo de desenvolvimento de coleções que permite correções na formação do acervo. Esse processo deve estar alinhado com o processo de avaliação e ocorrer de forma periódica.

As atividades que compõem o desbastamento são:

Remanejamento, que é a realocação de materiais no espaço da biblioteca a fim destacar os mesmos, quando a procura é bastante intensa para facilitar o acesso ou promover materiais que não apresentam registro de uso;

Restauro, trata-se da suspensão das obras danificadas de circulação por um prazo determinado, para restauro com a finalidade de recuperar sua integridade física.

Descarte, a retirada definitiva da obra do acervo, quando o material foi avaliado de acordo com os critérios estabelecidos na política e concluiu-se que o material não contribui mais com o acervo.

\subsection{Critérios para Descarte}

O descarte se faz necessário nas bibliotecas do IFSP para auxiliar na otimização do espaço, dos recursos físicos para a manutenção e para o desfazimento de materiais informacionais cuja vida útil se esgotou. Vergueiro $(1989$, p.75) alerta que a tomada de decisão no que se refere ao descarte é um "verdadeiro drama psicológico que muitas vezes impede o profissional de tomar a decisão correta, ou seja, retirar da coleção, definitivamente, aqueles materiais que não possuem justificativa alguma para nela permanecerem".

O descarte deve ser feito de acordo com critérios a seguir:

Obsolescência do conteúdo: conteúdo defasado;

Estatística de circulação: cinco anos sem empréstimos e consulta; 
૫ Condições físicas: mau estado de conservação; contaminação por fungos; falta de páginas/folhas, etc.;

( Duplicatas: número de exemplares não condizentes com a demanda;

૫ Inadequação: conteúdos não estão em harmonia com os objetivos da Instituição.

૫ Multimeios: falta de condições propícias de uso: danificados, ou obsoletos (sem condições de funcionamento).

Assim, após a análise das obras pautada nos critérios supramencionados, o descarte deve ser efetuado a fim de permitir que a coleção se mantenha dinâmica.

O desfazimento de materiais patrimoniados deve estar de acordo com o Decreto 99658/90, que regulamenta, no âmbito da Administração Pública Federal, o reaproveitamento, a movimentação, a alienação e outras formas de desfazimento de material.

\section{AVALIAÇÃO DE COLEÇÕES}

O processo de avaliação é fundamental para a harmonia da coleção. Tal etapa não pode ser negligenciada pelos bibliotecários devido a sua importância. A avaliação do acervo deve diagnosticar se todo o processo de desenvolvimento de coleções está ocorrendo da maneira prevista.

Desta forma, os bibliotecários devem realizar anualmente a avaliação da coleção das bibliotecas do IFSP a fim de auxiliar na tomada de decisões no que se refere ao remanejamento de itens, desbastamento, obsolescência dos conteúdos, itens para restauro e descarte.

Há duas abordagens que devem ser utilizadas no processo de avaliação da coleção concomitantemente, a saber: a abordagem qualitativa e a quantitativa. Os resultados obtidos devem ser comparados e analisados, permitindo, assim, o alcance dos objetivos da coleção.

A metodologia qualitativa deve ser realizada por meio da avaliação do acervo pelo corpo docente especialista do assunto. O bibliotecário deve solicitar a manifestação dos professores de cada área acerca da situação da coleção, no que se refere à atualidade, cobertura de assuntos e pontos fracos. Recomenda-se que a avaliação seja realizada por mais de um profissional para que se mantenha uma perspectiva imparcial.

A metodologia quantitativa deve ser realizada mediante a obtenção de dados estatísticos:

Tamanho do acervo, ou seja, distribuição percentual de materiais existentes em cada área do conhecimento e comparados com os cursos oferecidos e pesquisas 
em desenvolvimento. Tal análise demonstrará as áreas que encontram-se desprovidas de materiais informacionais;

Uso da informação: estatísticas de empréstimos e consultas dos materiais, as quais permitirão a determinação dos títulos que requerem duplicações devido à preferência de uso e daqueles, cuja duplicação é desnecessária.

A combinação das metodologias supramencionadas permite a elaboração de relações entre os materiais mais utilizados, os assuntos mais buscados, o crescimento do acervo, o grau de obsolescência e qualidade do acervo. Tais aspectos são necessários para o julgamento da adequação do acervo com as necessidades dos usuários, ou seja, irão nortear a tomada de decisão no que se refere à subutilização dos recursos bibliográficos em alguma área do conhecimento. 


\section{REFERÊNCIAS}

ANDRADRE, Diva; VERGUEIRO, Waldomiro. Aquisição de materiais de informação. Brasília: Brinquet de Lemos Livros, 1996.

BRASIL. Constituição da República Federativa do Brasil de 1988. Brasília:

1988. Disponível em:

http://www.planalto.gov.br/ccivil_03/constituicao/constituicaocompilado.htm. Acesso em: 5 jan. 2015.

. Decreto $\mathrm{n}^{\mathrm{o}} 3.931$, de 19 de setembro de 200, que regulamenta o Sistema de Registro de Preços previsto no art. 15 da Lei $\mathrm{n}^{\circ}$ 8.666, de 21 de junho de 1993, e dá outras providências. Brasília: 2001. Disponível em:

<http://www.planalto.gov.br/ccivil_03/decreto/2001/D3931htm.htm>. Acesso em: 5 jan. 2015.

Decreto $\mathrm{n}^{\mathrm{o}} 4.342$, de 23 de agosto de 2002, que altera dispositivos do

Decreto $n^{\circ} 3.931$, de 19 de setembro de 2001, que regulamenta o Sistema de Registro de Preços previsto no art. 15 da Lei no 8.666 , de 21 de junho de 1993, e dá outras providências. Brasília: 2002. Disponível em: <

http://www.planalto.gov.br/ccivil 03/decreto/2002/D4342.htm>. Acesso em: 5 jan. 2015.

. Decreto ${ }^{\circ} 5.450$, de 31 de maio de 2005, que regulamenta o pregão, na forma

eletrônica, para aquisição de bens e serviços comuns, e dá outras providências. Brasília: 2005. Disponível em:

<http://www.planalto.gov.br/ccivil 03/ ato2004-2006/2005/decreto/d5450.htm>. Acesso em: 5 jan. 2015.

Decreto $\mathrm{n}^{\mathrm{o}} 7.892$, de 23 de janeiro de 2013, que regulamenta o Sistema de Registro de Preços previsto no art. 15 da Lei ${ }^{\circ} 8.666$, de 21 de junho de

1993. Brasília: 2013. Disponível em: < http://www.planalto.gov.br/ccivil_03/_Ato20112014/2013/Decreto/D7892.htm>. Acesso em: 05 jan. 2015.

Decreto $n^{\circ}$ 99658, de 30 de outubro de 1990, que regulamenta, no âmbito

Administração Pública Federal, o reaproveitamento, a

movimentação, a alienação e outras formas de desfazimento de material. Brasília: 1990. Disponível em: < http://www.planalto.gov.br/ccivil_03/decreto/antigos/D99658.htm>. Acesso em: 2 mar. 2015. 
. Lei $\mathrm{n}^{\circ}$ 8.666, de 21 de junho de 1993, que regulamenta o art. 37, inciso XXI, da

Constituição Federal, institui normas para licitações e contratos da

Administração Pública e dá outras providências. Brasília: 1993. Disponível em: < http://www.planalto.gov.br/ccivil_03/leis/18666cons.htm>. Acesso em: 5 jan. 2015.

Lei ${ }^{\circ} 10.520$, de 17 de julho de 2002, que institui, no âmbito da União,

Estados, Distrito Federal e Municípios, nos termos do art. 37, inciso XXI, da Constituição Federal, modalidade de licitação denominada pregão, para aquisição de bens e serviços comuns, e dá outras providências. Brasília: 2002.

Disponível em: <http://www.planalto.gov.br/ccivil 03/leis/2002/110520.htm>. Acesso em: 5 jan. 2015.

Lei, $n^{\circ} 11.892$, de 29 de dezembro de 2008. Institui a Rede Federal de Educação

Profissional, Científica e Tecnológica, cria os Institutos Federais de

Educação, Ciência e Tecnologia, e dá outras providências. Diário Oficial [da]

República Federativa do Brasil, Brasília, DF, 30 de dez. 2008. Disponível em:

<http://www.jusbrasil.com.br/diarios/75589278/dou-secao-2-27-08-2014-pg14?ref=home>.

Acesso em: 27 ago. 2014.

COMPRASNET. Sistema de Registro de Pregão: perguntas e respostas.

[Brasília]: 2013?. Disponível em: < http://www.comprasnet.gov.br/ajuda/RegistroPreco.stm>. Acesso em: 5 jan. 2015.

CONTROLADORIA GERAL DA UNIÃO (CGU). Sistema de registro de preços: perguntas e respostas. Brasília: 2014. Disponível em:

$<$ http://www.cgu.gov.br/Publicacoes/auditoria-

efiscalizacao/arquivos/sistemaregistroprecos.pdf > . Acesso em 17 dez. 2015.

FIGUEIREDO, N. M. Desenvolvimento e avaliação de coleções. Rio de Janeiro: Rabiskus, 1986.

MINISTÉRIO DA EDUCAÇÃO. Instrumento de Avaliação de Cursos de Graduação presencial e a distância. Brasília: 2002. Disponível em: <

http://download.inep.gov.br/educacao_superior/avaliacao_cursos_graduacao/in strumentos/2012/instrumento_com_alteracoes_maio_12.pdf >. Acesso em 25 fev. 2015. 
306, de 13 de dezembro de 2001. [Brasília]: 2001. Disponível em: <

http://www.comprasnet.gov.br/legislacao/portarias/p306_01.htm>. Acesso em: 5 jan. 2015.

Pregão eletrônico: fornecedor. Brasília: [2014?]. Disponível em: <

http://www.comprasgovernamentais.gov.br/arquivos/manuais/manualpregaofornecedor 15122014.pdf> . Acesso em: 5 jan. 2015. Versão 1.

Pregão eletrônico: manual do fornecedor. Brasília: 2006. Disponível em:

$<$ http://www.comprasgovernamentais.gov.br/arquivos/manuais/manual pregao e letronico_versao_do_fornecedor_julho_2006.pdf>. Acesso em: 5 jan. 2015.

Portaria $\mathrm{n}^{\mathrm{o}} 1.003$, de 10 de março de $2014 \mathrm{~b}$, que dispõe sobre a delegação de competência aos diretores-gerais dos campi, quanto aos atos orçamentários, administrativos, financeiros e patrimoniais do Instituto Federal de Educação, Ciência e Tecnologia de São Paulo - IFSP. São Paulo: 2014. Disponível em: < http://www.ifsp.edu.br/index.php/component/search/?searchword=Portaria $+n \%$

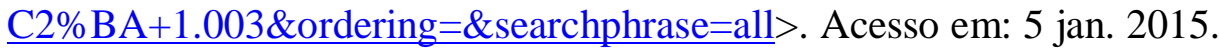

O HOMEM E A TÉCNICA: A experiência da Escola Técnica Federal de São Paulo. São Paulo: Departamento de Pedagogia e Apoio Didático, 1986.

ROSSETO, Márcia. Bibliotecas digitais: cenário e perspectivas. Revista Brasileira de Biblioteconomia e Documentação, v.4, n.1, p. 101-130, jan./jun. 2008.

VERGUEIRO, W. Seleção de materiais de informação: Princípios de técnicas. Brasília: Briquet de Lemos, 1995.

VERGUEIRO, W. Desenvolvimento de coleções. São Paulo: Associação Paulista de bibliotecários, 1989. 
APÊNDICE A - FORMULÁRIO DE SUGESTÃO DE USUÁRIO

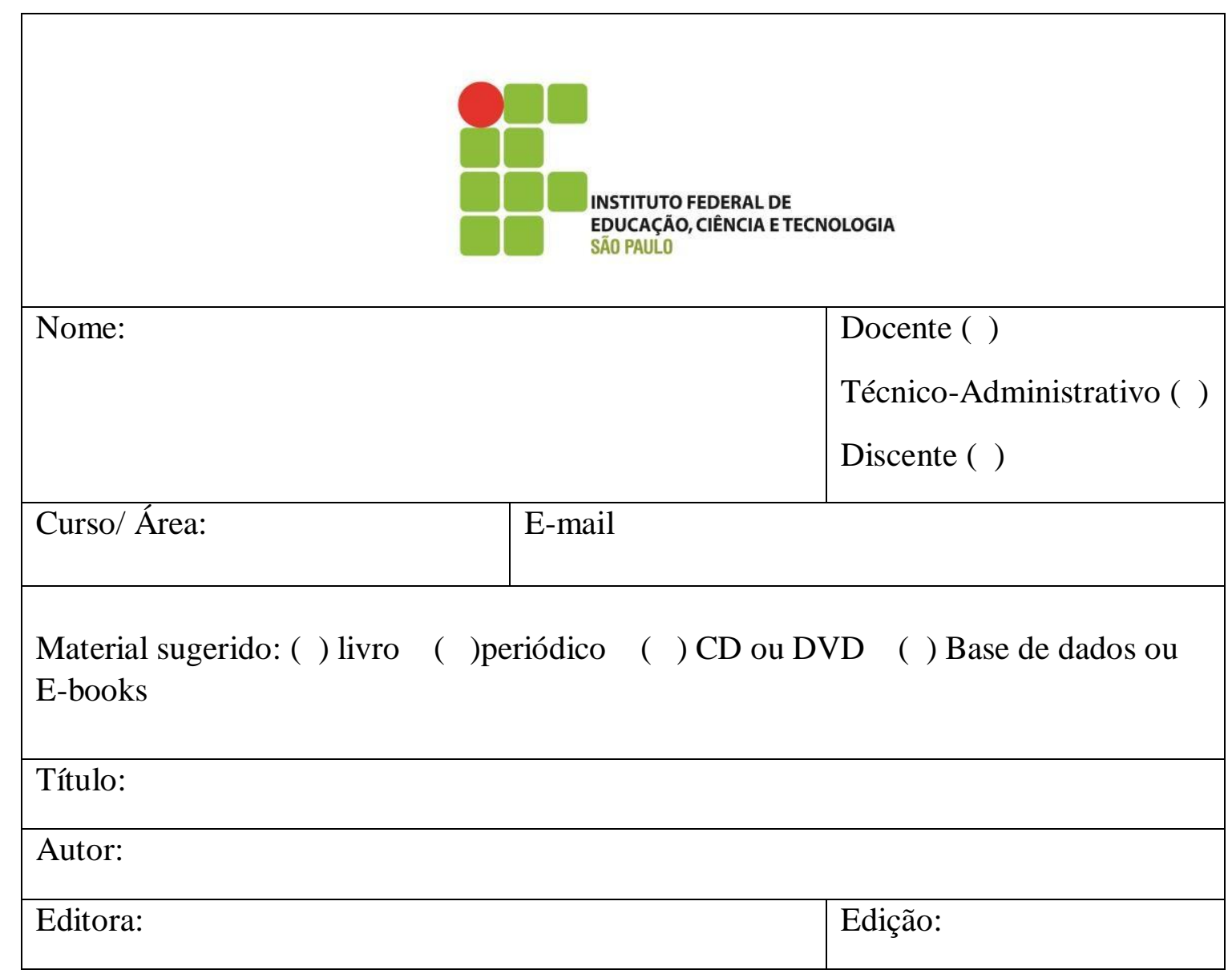


APÊNDICE B - TERMO DE DOAÇÃO

INSERIR LOGO DO CAMPUS

TERMO DE DOAÇÃO DE MATERIAL BIBLIOGRÁFICO

$\mathrm{Eu}$, , inscrito (a) no $\mathrm{CPF}$ de $\mathrm{n}^{\circ}$ efetuei, doação dos documentos listados anexos à biblioteca do Instituto Federal de Educação, Ciência e Tecnologia de São Paulo, Campus São Paulo, de acordo com o Procedimento para Doação de Materiais para a Biblioteca, garantindo a mesma autonomia para realizar a seleção qualitativa e quantitativa do material, podendo optar por incorporar, repassar, devolver ou descartar o material doado.

São Paulo, de de 20

(Assinatura)

Recebido por

Data 
Instituto Federal de Educação, Ciência e Tecnologia de São Paulo, Campus São Paulo Rua Pedro Vicente, 625 - Canindé - São Paulo - Brasil CEP 01109-010 - Telefone: (11) 2763-7553 / 2763-7578 